INTER NATIONAL MONETARY FUND

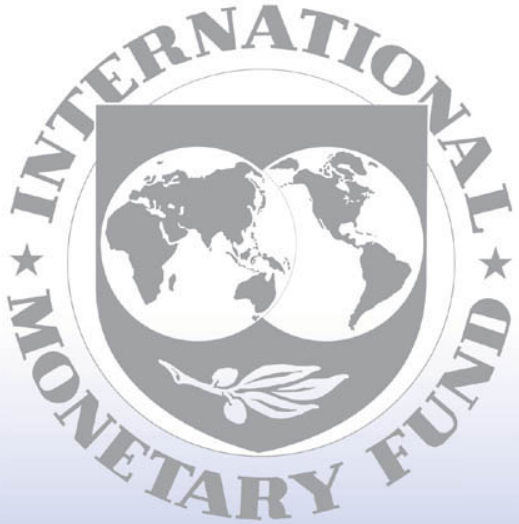

Staff

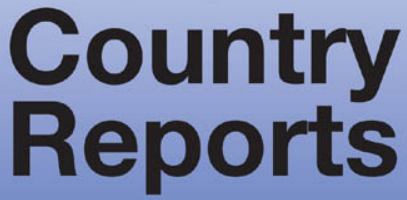




\section{Republic of Serbia: 2007 Article IV Consultation-Staff Report; Staff Statement; Public Information Notice on the Executive Board Discussion; and Statement by the Executive Director for the Republic of Serbia}

Under Article IV of the IMF's Articles of Agreement, the IMF holds bilateral discussions with members, usually every year. In the context of the 2007 Article IV consultation with the Republic of Serbia, the following documents have been released and are included in this package:

- $\quad$ The staff report for the 2007 Article IV consultation, prepared by a staff team of the IMF, following discussions that ended on November 6,2007, with the officials of the Republic of Serbia on economic developments and policies. Based on information available at the time of these discussions, the staff report was completed on December 28, 2007. The views expressed in the staff report are those of the staff team and do not necessarily reflect the views of the Executive Board of the IMF.

- $\quad$ A staff statement of January 24, 2008 updating information on recent developments.

- $\quad$ A Public Information Notice (PIN) summarizing the views of the Executive Board as expressed during its January 28, 2008 discussion of the staff report that concluded the Article IV consultation.

- $\quad$ A statement by the Executive Director for the Republic of Serbia.

The document listed below has been or will be separately released.

Selected Issues Paper

The policy of publication of staff reports and other documents allows for the deletion of market-sensitive information.

To assist the IMF in evaluating the publication policy, reader comments are invited and may be sent by e-mail to publicationpolicy@imf.org.

Copies of this report are available to the public from

International Monetary Fund $\bullet$ Publication Services

$70019^{\text {th }}$ Street, N.W. • Washington, D.C. 20431

Telephone: (202) 623-7430 • Telefax: (202) 623-7201

E-mail: publications@imf.org •Internet: http://www.imf.org

Price: $\$ 18.00$ a copy

International Monetary Fund

Washington, D.C. 
This page intentionally left blank

CInternational Monetary Fund. Not for Redistribution 


\section{INTERNATIONAL MONETARY FUND}

\section{REPUBLIC OF SERBIA}

\section{Staff Report for the 2007 Article IV Consultation}

Prepared by the Staff Representatives for the 2007 Consultation with Serbia

Approved by Juha Kähkönen and Michael T. Hadjimichael

December 28, 2007

Executive Summary

The Serbian economy, now in its seventh year of transition, continues to grow strongly with moderate inflation, but imbalances are widening and vulnerabilities increasing. Growth was boosted by inflows and expansionary policies. The inflows allowed for significant official reserve accumulation, but also complicated macro management by boosting credit and domestic demand. This was compounded by large wage increases. With mixed progress on structural reforms so far, the current account has deteriorated and competitiveness slipped. A more uncertain external environment and continuing political uncertainties have added to vulnerabilities.

To counter these trends and ensure sustainable economic growth, staff calls for a significant rebalancing of policies, with enhanced structural reforms and tighter fiscal policy, relieving the burden on monetary policy. This will include:

- Tightening fiscal policy significantly, as a restrictive fiscal stance is the main short-term macroeconomic tool available to curb domestic demand and reduce external imbalances. Specifically, fiscal surpluses are needed until the effects of structural reforms take hold.

- Focusing monetary policy on entrenching low inflation as part of a gradual move toward inflation targeting. Competitiveness concerns should be addressed through corporate restructuring and wage moderation rather than exchange rate intervention, which should focus on smoothing shocks.

- Reforming the corporate sector through privatization and, where necessary, bankruptcy proceedings, and further measures to improve the business climate.

- Strengthening the regulatory and supervisory framework to manage increasing financial sector risks. This requires continued monitoring of banks' resilience to shocks, contingency planning, and cross-border supervisory coordination. Developing capital markets will contribute to growth and financial stability in the medium term.

The authorities acknowledged the need to reduce external imbalances. They were more sanguine about risks to the economic outlook and favored a more gradual fiscal adjustment, while focusing on growth and employment. Budgetary expansion was seen as inevitable in 2008 given existing wage and pension commitments. The authorities agreed on accelerating enterprise restructuring and have prepared an ambitious plan for privatization of remaining socially and state-owned companies. 


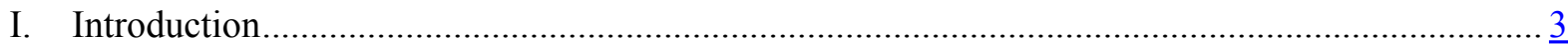

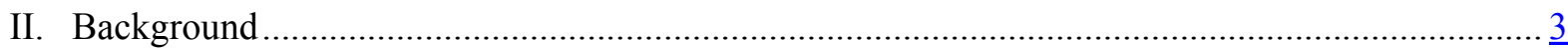

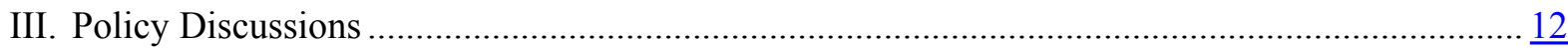

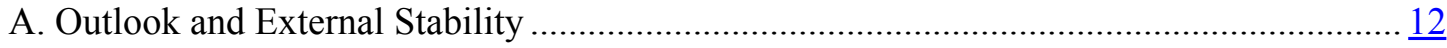

B. Restoring External Stability .............................................................................. 13

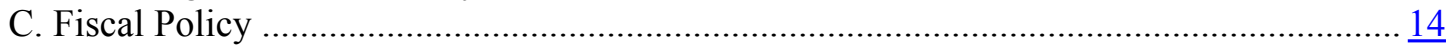

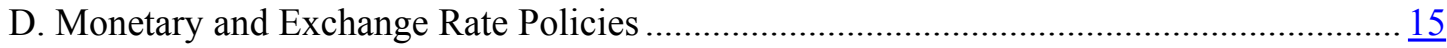

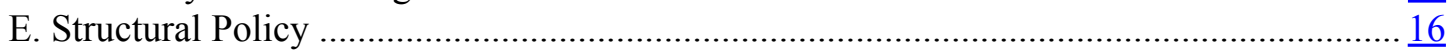

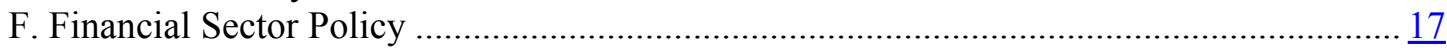

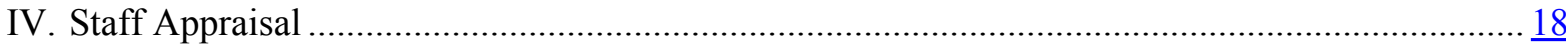

Text Boxes

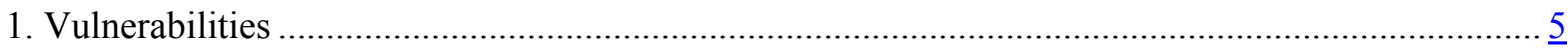

2. Financial Market Volatility in November-December 2007 .........................................................

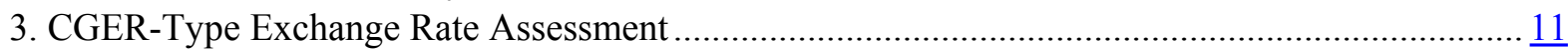

Figures

1. Serbia and Selected Neighboring Countries: Indicators Institutional Quality and Reform, 2007. 21

2. Serbia and Selected Neighboring Countries: External Balances and Growth, 2005-07 …........... 22

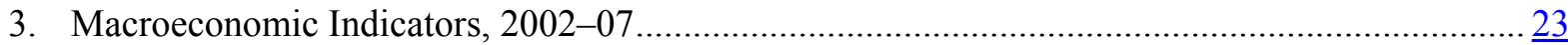

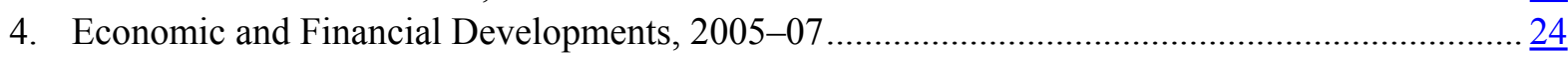

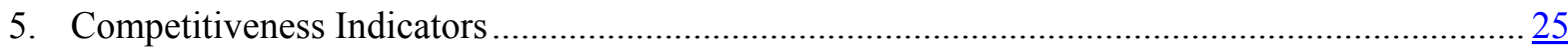

6. Emerging European Countries: Vulnerability Indicators, 2006 ............................................... $\frac{26}{27}$

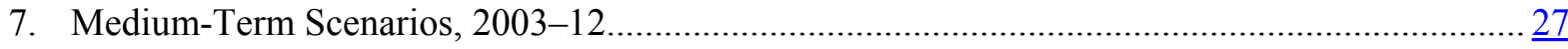

Tables

1. Authorities' Response to Past Policy Recommendations ............................................................... 29

2. Selected Economic and Financial Indicators, 2002-08 ……….................................................

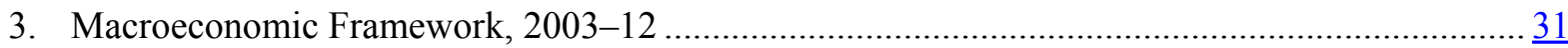

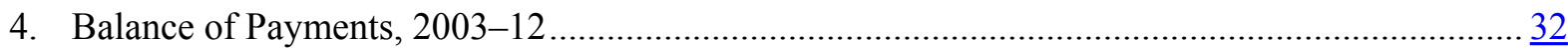

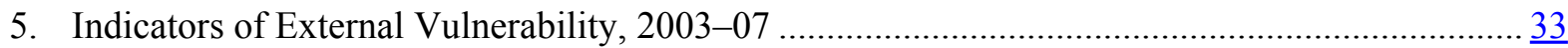

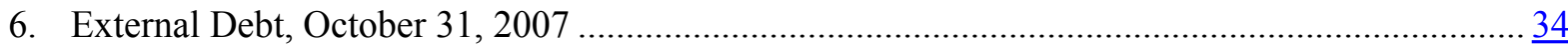

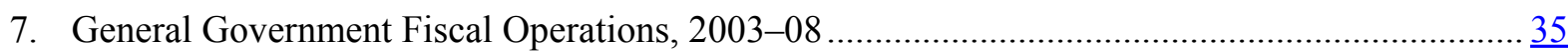

8. Government and Government-Guaranteed Debt, 2000-06 ………………………………......

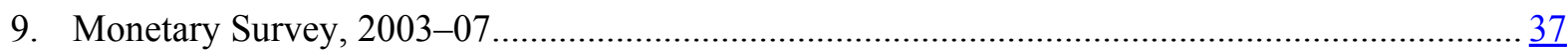

10. Banking Sector Financial Soundness Indicators, 2002-07 …….............................................

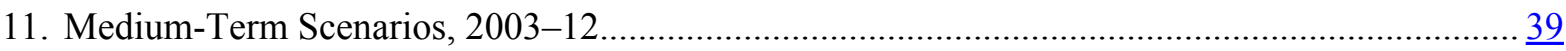

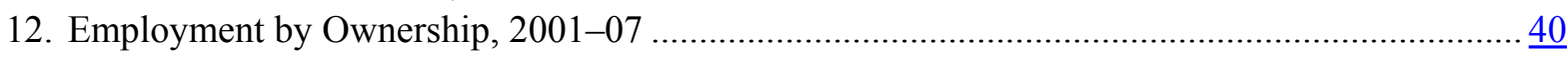

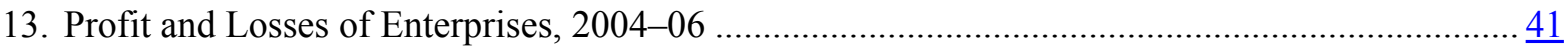

Appendices

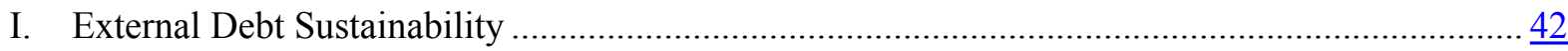

II. Public Debt Sustainability .............................................................................................. 


\section{INTRODUCTION}

\section{Since the last Article IV consultation, the Serbian economy—boosted by large} capital inflows and expansionary policies-continued to grow strongly, but external imbalances widened and vulnerabilities rose. The inflows allowed significant official reserve accumulation, but at the same time complicated macroeconomic management by boosting credit and domestic demand. This was compounded by expansionary fiscal and wage policies. With tight monetary policy aimed at containing inflation and slow-moving structural reforms, the external current account deteriorated and competitiveness slipped. Rising private foreign debt and euroized credit, along with a worsened external environment, increased vulnerabilities.

2. The political situation remains unsettled. The coalition government formed in May - following a constitutional referendum and parliamentary elections - was well received by the international community, and its stepped-up cooperation with the International Criminal Tribunal (ICTY) led to the initialing of a Stability and Association Agreement (SAA) with the EU. However, the unresolved Kosovo status issue dominates the political agenda, the EU accession process still faces hurdles, and political campaigning continues ahead of presidential and local elections likely to be held in early 2008. This weighs heavily on economic prospects.

\section{BACKGROUND}

3. Serbia continues to grow strongly - a welcome result of the structural reforms of the past (Table 2). The economy has undergone significant changes since 2000: inflation has come down to single digits; the banking sector was restructured; and hundreds of companies were privatized - doubling the private sector share in non-budget non-agricultural employment to about 61 percent. As a result, the corporate sector posted aggregate profitsfor the first time in years-in 2006 (Table 13). These transformations helped raise output by about 46 percent since 2000. After reaching an impressive 8 percent in the first half of 2007, GDP growth is projected to settle at about 7 percent for the year, notwithstanding droughtrelated losses in agriculture.

\section{However, sustaining the reform momentum has been a challenge and}

weaknesses in the corporate sector persist. Hampered by political uncertainties, structural reforms stalled in 2006-07. Consequently, substantial progress - and growth - has been achieved only in a handful of sectors, and the business environment is in its early stages of transformation (Figure 1). State- and socially owned enterprises, including large monopolies, continue to drain domestic savings while fixed investment remains low (Figure 2). With slow

Serbia: Savings-Investment Balances (In percent of GDP)

\begin{tabular}{|c|c|c|c|}
\hline & 2005 & 2006 & 2007 \\
\hline Gross fixed capital form. & 17.3 & 17.6 & 18.4 \\
\hline Foreign savings & 9.6 & 11.5 & 15.5 \\
\hline National savings & 11.3 & 10.4 & 6.5 \\
\hline
\end{tabular}

Source: Serbian authorities; and Fund staff estimates. 
job creation, employment continued declining and unemployment remained high at 21 percent in 2006 (Table 12).

\section{Despite these concerns, capital inflows have surged since end-2005. Improved} economic performance strengthened investor sentiment, and - in combination with a stronger banking sector and financial markets' increased interest in emerging countries - led to a sharp rise in capital inflows. FDI and capital transfers spiked to 17 percent of GDP in 2006 , boosted by privatization and the sale of telecom licenses. In 2007, these inflows abated as privatization stalled in the first half of the year. Foreign borrowing - mostly medium- and longterm - also surged, mainly by nonbanks. Consequently, external debt, boosted by private debt, rose despite rescheduling operations and early repayments to multilateral creditors.

Serbia. Capital Inflows, 2005-07 (Percent of GDP)

\begin{tabular}{lrrr}
\hline & 2005 & 2006 & $\begin{array}{c}2007 \\
\text { Jan.-Oct. }\end{array}$ \\
\hline Total & 18.1 & 33.8 & 20.7 \\
Non debt creating & 8.0 & 21.0 & 9.5 \\
$\quad$ FDI and portfolio, net & 5.9 & 17.4 & 5.3 \\
$\quad$ Other & 2.1 & 3.6 & 4.3 \\
Debt creating & 10.1 & 12.8 & 11.1 \\
$\quad$ Net borrowing by: & & & \\
$\quad$ Public sector & 0.9 & 0.5 & 0.5 \\
$\quad$ Banks & 4.8 & 6.4 & -1.1 \\
$\quad$ Private nonbank & 4.4 & 5.9 & 11.7 \\
\hline
\end{tabular}

Source: NBS and staff estimates.

\section{The large inflows - combined with rapid credit growth and expansionary} domestic policies-led to rising external deficits and vulnerabilities (Box 1; Tables 4-6). ${ }^{1}$ Credit growth, compounded by large wage increases of 20-30 percent in the public sector, income tax cuts, and fiscal relaxation ahead of the January 2007 elections, supported robust growth in 2007. But given domestic supply rigidities, the surge in demandcombined with real exchange rate appreciation and a drop in remittancesled to a widening of the current account deficit to $16 \frac{1}{2}$ percent of GDP in January-October (Figures 34). Driven by fast-growing Macroeconomic Developments, 2004-07

\begin{tabular}{lrrrrrr}
\hline & 2004 & 2005 & 2006 & \multicolumn{2}{c}{2007} \\
\cline { 3 - 6 } & \multicolumn{5}{c}{ (Annual change in percent) } \\
Real GDP & 8.4 & 6.2 & 5.7 & 8.0 & H1 \\
Retail price inflation (end of period) & 13.7 & 17.7 & 6.6 & 8.8 & Nov. \\
Of which: Core inflation & 11.0 & 14.5 & 5.9 & 4.5 & Nov. \\
& & (In percent of GDP) & \\
Current account balance & $1 /$ & -12.4 & -10.9 & -12.2 & -16.4 & Jan-Oct. \\
External debt & 57.5 & 58.9 & 61.7 & 62.6 & Oct. \\
Of which: Private debt & 18.1 & 24.1 & 35.1 & 39.8 & Oct. \\
\hline
\end{tabular}

Source: Serbian authorities; and Fund staff estimates.

1/ Corrected for the impact of the VAT introduction in 2005. Excl. grants. imports, the trade balance worsened despite improved terms of trade and a strong performance of exports in newly privatized sectors.

\footnotetext{
${ }^{1}$ Selected Issues Chapter I presents an overview of vulnerabilities.
} 


\section{Box 1. Vulnerabilities}

By many measures, Serbia is among the vulnerable countries in the region, with rising external and financial sector vulnerabilities (Figure 6).

\begin{tabular}{|c|c|c|c|}
\hline Vulnerability & Trend & Manifested in: & Main causes \\
\hline External & Rising & $\begin{array}{l}\text { High and rising current account deficit and } \\
\text { external debt, both among the largest in the } \\
\text { region. Rising financing requirements and } \\
\text { uncertain FDI inflows. }\end{array}$ & $\begin{array}{l}\text { Transition factors exacerbated by weak } \\
\text { corporate structures and large capital } \\
\text { inflows, over half of which are debt- } \\
\text { creating. Limited share of "greenfield" FDI. }\end{array}$ \\
\hline Financial & Rising 1/ & $\begin{array}{l}\text { Rapid growth of household credit coupled } \\
\text { with high euroization, unhedged domestic and } \\
\text { off-shore borrowing, which is partly } \\
\text { guaranteed by domestic banks, high ratios of } \\
\text { risky assets. }\end{array}$ & $\begin{array}{l}\text { Capital inflows, relaxed wage policies, } \\
\text { transition factors, aversion to dinar lending } \\
\text { due to past history of high inflation, } \\
\text { underdeveloped capital markets. }\end{array}$ \\
\hline Public sector & Stable & $\begin{array}{l}\text { Relatively stable public sector debt, but fiscal } \\
\text { slippages, rigidities in public expenditure, and } \\
\text { accelerated spending of privatization revenue } \\
\text { may resurrect sustainability concerns } \\
\text { (Appendix II). }\end{array}$ & $\begin{array}{l}\text { Paris Club and London Club debt write-offs } \\
\text { and privatization receipts. High share of } \\
\text { current spending. }\end{array}$ \\
\hline
\end{tabular}

1/ Subject to uncertainty due to lack of data on maturity/currency composition of assets and non-performing loans.

The high reserve cover is a mitigating factor, but should be interpreted with caution, as gross reserves are partly matched by large short-term central bank obligations.

Vulnerability Indicators for Selected Emerging Economies, 2006

\begin{tabular}{lccccc}
\hline & $\begin{array}{c}\text { Current } \\
\text { account } \\
\text { balance 1/ }\end{array}$ & $\begin{array}{c}\text { Reserve } \\
\text { cover 2/ }\end{array}$ & $\begin{array}{c}\text { External debt } \\
1 /\end{array}$ & $\begin{array}{c}\text { Primary fiscal } \\
\text { balance 1/ }\end{array}$ & $\begin{array}{c}\text { Credit } \\
\text { euroization 3/ }\end{array}$ \\
\hline Bosnia\&Herzegovina & & & & & \\
Bulgaria & -11.5 & 221 & 50.7 & -0.2 & 71.0 \\
Croatia & -15.8 & 135 & 78.4 & 3.7 & 73.0 \\
Romania & -7.8 & 100 & 89.1 & -0.7 & 68.3 \\
Serbia & -10.3 & 125 & 42.4 & -1.8 & 60.8 \\
Ukraine & -11.5 & $3064 /$ & 61.7 & -0.1 & 79.6 \\
Average, all emerging countries & -1.5 & 103 & 49.5 & -2.0 & 49.4 \\
\hline Sources: Staff estimates & -2.1 & 309 & 48.9 & 1.3 & 54.6 \\
\hline
\end{tabular}

Sources: Staff estimates and WEO.

$1 /$ In percent of GDP.

2/ In percent of short-term debt plus amortization of medium- and long-term debt in 2007.

$3 /$ Percent of $\mathrm{fx}$-indexed and $\mathrm{fx}$-denominated credit in total domestic credit.

4/ The reserve cover drops to 122 percent (3 months of imports) after accounting for commercial banks' forex required reserves at the central bank and the stock of two-week NBS bills outstanding. 
7. Expansionary fiscal policies added to the widening of external imbalances (Tables 7-8). The primary fiscal balance deteriorated by over 2 percent of GDP between 2005 and 2007. Accelerated implementation of the National Investment Plan (NIP), extraordinary repayment of pension arrears, and government wage overruns at the end of 2006 caused a fiscal deficit of 1.5 percent of GDP_-some 4 percentage points adrift of the target envisaged in February 2006 under the Extended

Arrangement — adding to the rising current account deficit. In 2007, despite a surplus of

Change in the Primary Fiscal Balance, 2005-07 (In percent of GDP)

\begin{tabular}{lrrrr}
\hline & 2005 & 2006 & 2007 & $2005-07$ \\
\hline Overall fiscal balance & 0.7 & -1.5 & -1.0 & -1.8 \\
Primary fiscal balance & 2.2 & -0.1 & -0.1 & $\ldots$ \\
$\quad$ change & $\ldots$ & -2.3 & 0.0 & -2.3 \\
$\quad$ Contributions from: & & & & \\
$\quad$ Revenues & $\ldots$ & -0.6 & 0.6 & 0.0 \\
$\quad$ Primary expenditures & $\ldots$ & -1.7 & -0.6 & -2.3 \\
$\quad$ Current primary spending & $\ldots$ & -0.4 & -0.2 & -0.6 \\
$\quad$ Capital spending & $\ldots$ & -1.2 & -0.4 & -1.6 \\
\hline
\end{tabular}

Source: Serbian authorities; and Fund staff estimates.

$1 / 4$ percent of GDP through October — aided by a cap on expenditures due to the absence of a budget early in the year - a deficit of about 1 percent of GDP is projected, with an expected spending acceleration in the remaining two months.

\section{Despite prudential tightening, credit growth remained largely unabated, as} competition in the banking sector-dominated by foreign banks-intensified (Tables 910). Notwithstanding the tightening of macro-prudential regulations by the National Bank of Serbia (NBS) at end-2006, credit grew by 28 percent annually in real terms in October, mostly driven by highly euroized household credit. Moreover, a slowdown in domestic credit to enterprises - due to reserve requirements of 40-45 percent on foreign exchange liabilities - was partly offset by increased off-shore borrowing. ${ }^{2}$ Thus, total-including offshore—-bank credit continued to grow rapidly, reaching 40 percent of GDP in August 2007.
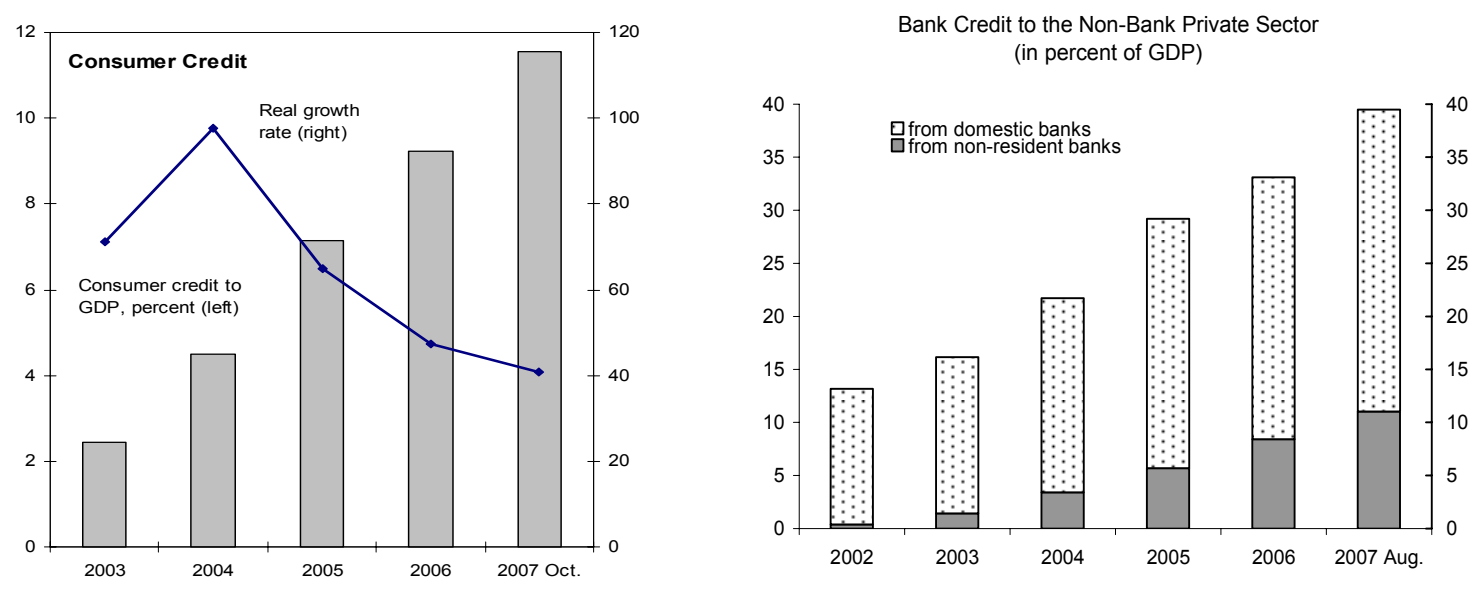

\footnotetext{
${ }^{2}$ Selected Issues Chapter II reviews corporate sector vulnerabilities.
} 
Subsequently, a new set of measures seems to have slowed consumer credit growth - at least temporarily. ${ }^{3}$

\section{High credit growth and euroization have increased financial sector}

vulnerabilities. ${ }^{4}$ Risks from high credit growth are compounded by high credit euroization (over 70 percent). Intense competition among banks raises concerns over a possible deterioration of asset quality and profitability, especially in the event of a downturn. A survey of the nine largest banks revealed a 43 percent increase in non-performing household loans during the first half of 2007.5

10. But banking sector soundness has so far been preserved. Rigorous risk classification rules and high provisioning, reserve, and capital requirements have resulted in a high risk-weighted capital adequacy ratio of over 25 percent in June 2007. The nonperforming loans of the banking system, although relatively high, have been well provisioned.

\section{The new monetary policy framework has so far been successful in achieving low} inflation, despite a pickup at end-2007. The framework - introduced in September 2006aimed at a gradual transition towards inflation targeting with explicit objectives for core inflation. The latter declined from 14.5 percent at end-2005 to about 6 percent at end-2006, aided by double-digit real appreciation resulting from high NBS interest rates. Despite

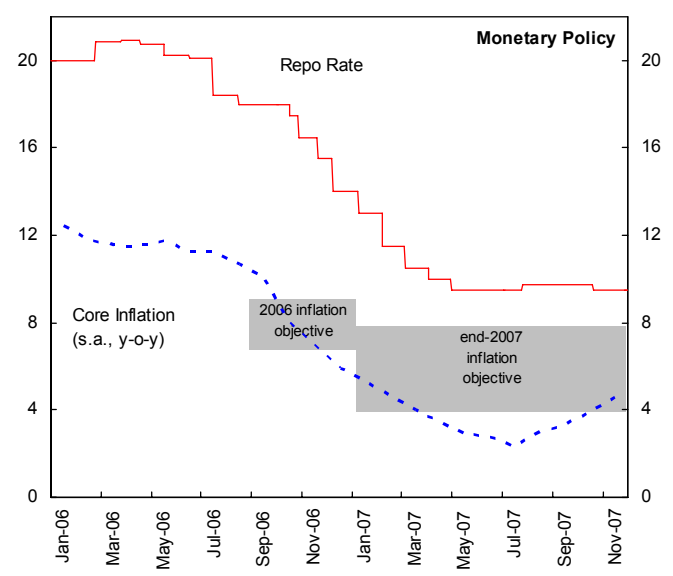

Retail Price Index, 2005-07

(12-month change in percent, end of period)

\begin{tabular}{lrrrr}
\hline & $\begin{array}{r}\text { Weight in } \\
\text { RPI (2007) }\end{array}$ & 2005 & 2006 & $\begin{array}{r}2007 \\
\text { Nov. }\end{array}$ \\
\hline Retail price index (RPI) & 100 & 17.7 & 6.6 & 8.8 \\
Non-core, of which: & 49 & 21.1 & 7.4 & 13.2 \\
Electricity & 7 & 6.6 & 11.7 & 15.0 \\
Oil and gasoline & 9 & 23.1 & 1.1 & 12.8 \\
Agricultural products & 3 & 36.1 & 6.4 & 24.1 \\
Household utilities & 9 & 47.1 & 3.0 & 10.3 \\
Core, of which: & 51 & 14.5 & 5.9 & 4.5 \\
Non-food goods & 22 & 11.7 & 5.6 & 3.6 \\
Food (excl. beverages) & 17 & 17.9 & 5.1 & 6.7 \\
Services & 8 & 18.5 & 7.2 & 2.5 \\
\hline
\end{tabular}

Source: Statistics Office.

\footnotetext{
${ }^{3}$ Measures included shortening the maturity of cash loans from ten to two years and lowering the cap on retail lending from 200 to 150 percent of capital.

${ }^{4}$ Selected Issues Chapter III discusses vulnerabilities arising from the growth in household borrowing.

${ }^{5}$ The household non-performing loan (NPL) ratio was 4.4 percent in June 2007. While the overall NPL ratio of these banks reached 10.4 percent in June, it was 3.5 percent after accounting for provisions.
} 
several cuts in the repo rate, ${ }^{6}$ monetary policy remained conservative in 2007 , in anticipation of inflationary pressures from rising demand, as well as a drought-related spike in food prices in August. In November 2007, core inflation stood at 4.5 percent-at the lower bound of the 4-8 percent target range for the year-while headline inflation reached 8.8 percent, reflecting rising energy and utility prices.

\section{But with large capital inflows, the tight monetary policy stance resulted in sharp} nominal appreciation in 2006, which persisted through most of 2007. The NBS actively participated both ways in the foreign exchange market in 2006-accommodating foreign inflows via purchases at a premium from foreign exchange bureaus, and occasionally intervening to prevent excessive depreciation. ${ }^{7}$ The purchases, combined with privatization receipts, inflows into NBS securities, and private credit flows, boosted official reserves to over $\$ 14 \frac{1}{2}$ billion by end-November 2007 (71/2 months of imports). Direct intervention diminished in 2007 and was limited to smoothing shocks, and the NBS announced the removal of the premium paid to the bureaus by end-2007. The exchange rate remained broadly stable in the first half of the year, but became more volatile since September, initially driven by high inflows following the announcement of higher bank capital requirements, and

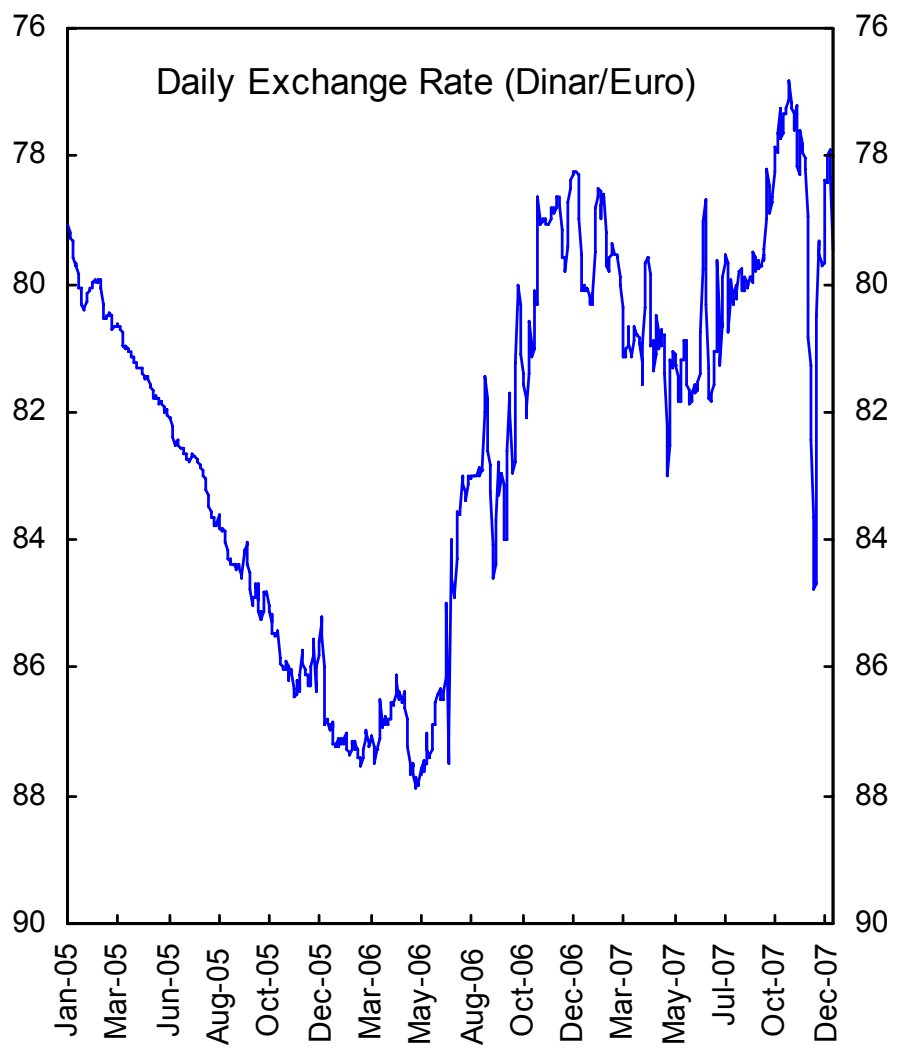
subsequently by increased stock market volatility and heightened Kosovo-related uncertainties (Box 2).

\footnotetext{
${ }^{6}$ The repo rate was cut from a high of 18 percent in November 2006 to 9.5 percent in July 2007.

${ }^{7}$ The exchange rate arrangement is a managed float. Serbia has accepted the obligations under Article VIII and maintains a system free of restrictions on payments and transfers for current international transactions, except with respect to blocked pre-1991 foreign currency savings deposits (IMF Country Report No. 02/105).
} 


\section{Box 2. Financial Market Volatility in November-December 2007}

The initial impact on Serbia of the global market turmoil was limited. Spreads in external sovereign bond markets rose-broadly in line with other emerging markets - but they had little impact on domestic financial markets.

In the last two weeks of November, however, both the exchange rate and the stock market declined by over 9 percent, and spreads shot up significantly. The less favorable external environment was combined with a growing unease about the outcome of the Kosovo status discussions. The tensions abated in early December.

The volatility in financial markets underscores the key importance of stability-oriented economic policies and contingency

planning. During times of potential turmoil, markets will be closely watching political and economic developments. Strong macro policies focused on reducing imbalances and limiting vulnerabilities, coupled with forceful implementation of structural reforms - as recommended in this report—will be a major factor in maintaining stability during uncertain political times. In addition, the authorities should further develop contingency plans to deal with financial and external sector shocks.
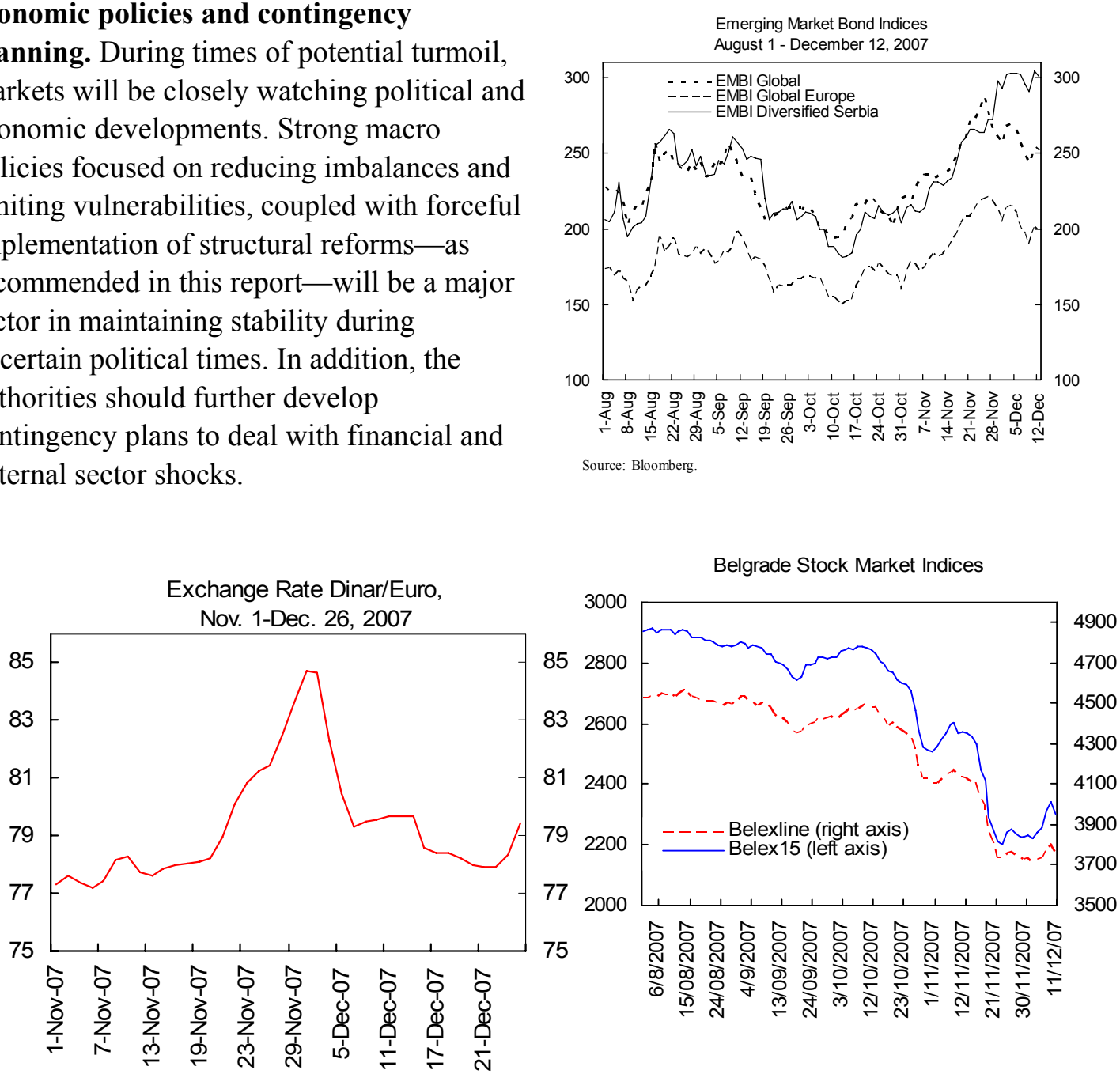


\section{Various estimates point to real exchange rate overvaluation, although its extent} is uncertain. CGER-type estimates suggest overvaluation in the range of 5-16 percent (Box 3). ${ }^{8}$ The wide range reflects Serbia's short history of transition-following a decade of conflict and isolation - and the uncertainties related to the resolution of Kosovo and EU accession issues. Other competitiveness indicators broadly support this assessment, although with a more mixed picture

(Figure 5). Large pay raises granted ahead of the elections continued well into 2007, and brought annual average real wage growth to 21 percent through October. In industry, wage growth outstripped productivity gains in 2006, but this was partly reversed in the first half of 2007, thereby moderating the rise in unit labor costs. Similarly, export shares remained on an upward trend despite the sharp real effective exchange rate appreciation over the past year and a half, which exceeded most of Serbia's neighbors.

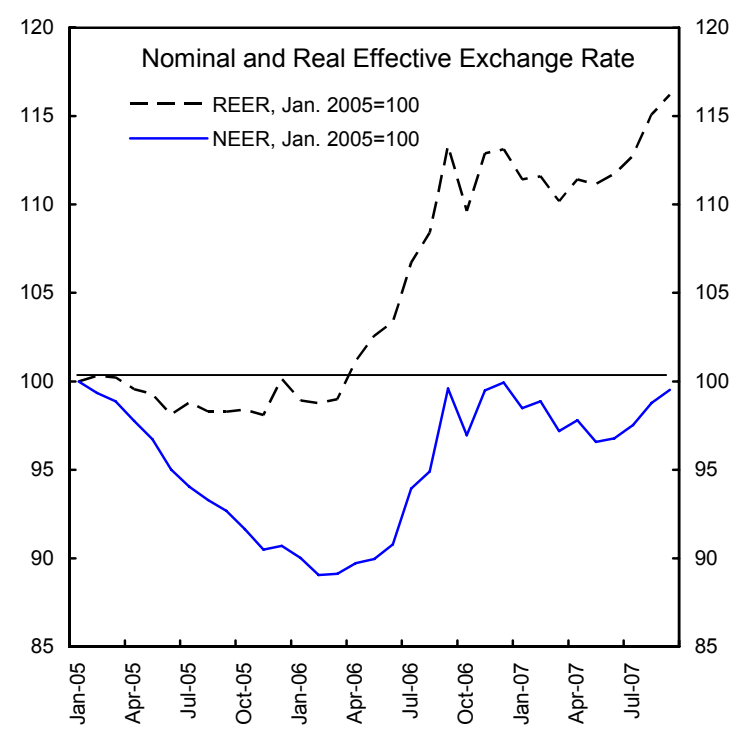

Merchandise Exports: Share of Serbia's exports in ...

\begin{tabular}{lrrrrrrr}
\hline & 2001 & 2002 & 2003 & 2004 & 2005 & 2006 & $20071 /$ \\
\hline$\ldots$ total world imports $(2001=100)$ & 100 & 121 & 124 & 228 & 254 & 290 & 335 \\
$\ldots$ GDP (in percent) & 9.7 & 9.1 & 8.5 & 15.8 & 18.7 & 20.2 & 21.7 \\
\hline
\end{tabular}

Source: Serbian authorities, IMF Direction of Trade Statistics, and staff estimates.

$1 /$ January-July.

${ }^{8}$ Selected Issues Chapter IV. 


\section{Box 3. CGER-Type Exchange Rate Assessment}

CGER-type methodologies tentatively point to an overvaluation of the real exchange rate in the range of 5-16 percent. The assessment is at current policies, stripped of temporary factors and the effects of projected terms of trade and REER changes.

These are only broad estimates and should be considered with caution. Major structural changes in the past two decades, the incomplete state of transition, and significant uncertainties ahead-e.g. regarding the Kosovo status and the EU accession track - complicate the definition of fundamentals and the measurement of the underlying current account. In particular, the latter is blurred by the difficulty to calculate the output gap and by uncertainties related to the recent drop in remittances. It is unclear whether this drop is temporary or permanent (the calculations assume it is temporary, in part because of frequent data revisions). Moreover, data limitations are important.

CGER-Type Real Exchange Rate Assessment 1/

\begin{tabular}{|c|c|c|c|}
\hline & \multirow[b]{2}{*}{$\begin{array}{l}\text { Macrobalance } \\
\text { approach (MB) }\end{array}$} & \multicolumn{2}{|c|}{ External stability approach (ES) $2 /$} \\
\hline & & $\begin{array}{c}\text { NFL stabilized } \\
\text { at estimated end-07 } \\
\text { level } \\
\text { (66 percent of GDP) }\end{array}$ & $\begin{array}{c}\text { NFL stabilized at } \\
83 \text { percent of GDP } 3 /\end{array}$ \\
\hline $\begin{array}{l}\text { Norm }(\mathrm{MB}) \text { or required }(\mathrm{ES}) \text { medium-term CA } \\
\text { (percent of GDP) }\end{array}$ & -3.8 & $-4.8 /-5.2$ & $-6.1 /-6.6$ \\
\hline $\begin{array}{l}\text { Underlying current account } 4 \text { / } \\
\text { (percent of GDP) }\end{array}$ & -7.9 & -7.9 & -7.9 \\
\hline CA elasticity to REER & -0.25 & -0.25 & -0.25 \\
\hline Implied REER adjustment (percent) & -16.4 & $-12.4 /-10.8$ & $-7.3 /-5.3$ \\
\hline
\end{tabular}

Source: staff estimates.

1/ The assessment was carried out using standard CGER parameters, including for the current account elasticity.

2/ For each variant, the first estimate uses staff's conservative medium-term growth rate (5.5 percent). The second assumes that clearer EU accession prospects and resolution of the Kosovo status brings about higher FDI, productivity, and growth at unchanged economic policies. For calibration purposes, the 2003-07 average growth rate for 15 Eastern European countries (6.2 percent) is used. $3 /$ Because of the difficulty to define a desirable NFL target given Serbia's incomplete transition process, the target for this variant was calibrated as the mid-point between Serbia's projected 2007 level and the maximum NFL position observed in recent years in Eastern European countries (close to 100 percent of GDP in Hungary and Estonia.)

4/ Derived from staff medium-term projections at current policies, stripped of projected changes in REER and terms of trade. The former explains 3.6 percent of GDP of the difference between the projected and underlying current accounts and the latter 2.3 percent of GDP. 


\section{Policy Discussions 9}

\section{With the authorities aware of, but more sanguine than staff about rising} vulnerabilities, discussions focused on assessing external and financial stability, and on policy options. The authorities aim at increasing employment through higher growth boosted by improved infrastructure, and anchor their policies to the objective of eventual EU membership. While conscious of macro imbalances, they considered those as temporary and reflecting the convergence process, and pointed to the large capital inflows as proof of market confidence. Staff emphasized the widening external imbalances and the recent global markets turmoil, which have raised vulnerabilities and heightened the risks to external stability brought about by unbalanced domestic policies. Consequently, and in line with earlier Fund advice (Table 1), staff underscored the need for policy-makers to act now to limit the rising risks by adopting a policy mix that ensures macro and financial stability, reduces imbalances and vulnerabilities, and supports growth through structural reforms.

\section{A. Outlook and External Stability}

\section{Under current policies, staff's medium-term outlook points to persistent external} imbalances leading to rising indebtedness (Figure 7, Tables 3 and 11). According to staff's baseline scenario, real appreciation, insufficient progress on structural reforms, and loose fiscal policies will dampen growth prospects (down to $5 \frac{1}{2}$ percent) and FDI inflows. With restrictive monetary policy needed to contain inflation, the underlying current account would improve only marginally — compounded by a deterioration in terms of trade reflecting declining metal prices. Capital account vulnerabilities would increase along with rising external debt and continued euroized credit growth (Appendix I).

\section{The authorities viewed staff's outlook as too pessimistic, while agreeing that} competitiveness had deteriorated. They noted that continued FDI and expected proceeds from divestiture of state-owned assets would facilitate the financing of current account deficits. By generating productive investment, these would also address competitiveness problems and foster sustained growth.

\section{Staff stressed that both upside and downside risks were significant. It}

acknowledged that orderly resolution of the Kosovo status and rapid progress toward EU accession would significantly improve economic prospects. This would lead to higher FDI inflows and a pickup in investment, exports, and growth. However, given the uncertainties, staff's baseline projections did not incorporate changes in the political environment. Staff also warned that downside risks would be aggravated in the event of disorderly resolution of

\footnotetext{
${ }^{9}$ Discussions were held in Belgrade during October 25 - November 6 (see Informational Annex for details on mission composition and counterparts).
} 
the Kosovo status issue, and that increased global volatility raised uncertainties to the economic outlook.

\section{B. Restoring External Stability}

18. Despite broad agreement on the medium-term policy agenda and the need to preserve macroeconomic stability, views differed on the urgency of short-term steps, particularly the role of fiscal and monetary policies. Staff called for immediate and significant policy adjustment to reduce the large imbalances, prevent a rapid build-up of vulnerabilities, and ensure high and sustainable growth in the medium term. In particular, it emphasized the importance of:

- Accelerating structural reforms - notably privatization and bankruptcy reform-to achieve higher economic and export growth and reduce the burden on demand management;

- Strengthening fiscal and wage policies to reduce domestic demand, restore external competitiveness, and alleviate pressures on monetary policy;

- Pursuing low inflation — critical for macro stability—-through continued transition towards inflation targeting; and

- Ensuring the financial system's stability and resilience to shocks.

19. Staff presented a first-best reform scenario aiming at restoring external stability through accelerated structural reforms supported by tight fiscal policy (Figure 7 , Table 11). In this scenario, accelerated privatization and bankruptcies would lead to corporate restructuring and increase potential growth through higher corporate savings, investment, and exports. Tight fiscal policy would help contain domestic demand (although impacting growth in the short term) while allowing careful monetary relaxation. Combined, these policies would help restore competitiveness and contribute to current account adjustment. ${ }^{10}$ They would also lower the private debt ratio and increase the resilience of external debt to exchange rate and FDI shocks, thereby reducing risks to external stability stemming from the capital account.

\section{Staff emphasized the trade-off between fiscal and structural measures in the} medium term. Accelerated structural reforms are key, as they alleviate the burden on fiscal policies. However, these take time to be reflected in rising corporate savings, and private sector imbalances may persist on account of a continued credit boom. Thus, staff's proposed scenario called for a sharp and front-loaded fiscal adjustment to secure external

\footnotetext{
${ }^{10}$ Selected Issues Chapter V finds a clear "twin deficits" relation between fiscal and current account balances.
} 
Macroeconomic Framework, 2005-08

\begin{tabular}{|c|c|c|c|c|c|c|}
\hline & \multirow[t]{2}{*}{2005} & \multicolumn{2}{|c|}{2006} & \multirow{2}{*}{$\begin{array}{l}2007 \\
\text { Proj. }\end{array}$} & \multicolumn{2}{|c|}{2008} \\
\hline & & $\begin{array}{c}\text { PPM } \\
1 /\end{array}$ & Est. & & $\begin{array}{c}\text { Proj. } \\
21\end{array}$ & $\begin{array}{c}\text { Staff } \\
3 /\end{array}$ \\
\hline & \multicolumn{6}{|c|}{ (In percent of GDP) } \\
\hline General government fiscal balance 4/ & 0.7 & 2.4 & -1.5 & -1.0 & -1.8 & 1.0 \\
\hline Revenue & 41.3 & 40.8 & 40.7 & 41.3 & 41.2 & 41.2 \\
\hline Expenditure & 40.6 & 38.4 & 42.3 & 42.3 & 43.0 & 40.2 \\
\hline Current account balance $5 /$ & -10.9 & -9.2 & -12.2 & -16.1 & -16.5 & -14.4 \\
\hline External debt & 58.9 & 51.2 & 61.7 & 62.0 & 62.6 & 60.6 \\
\hline \multirow[t]{2}{*}{ of which: Private debt } & 24.1 & $\ldots$ & 35.1 & 41.4 & 44.1 & 41.8 \\
\hline & \multicolumn{6}{|c|}{ (Annual change in percent) } \\
\hline Real GDP & 6.2 & 5.0 & 5.7 & 7.0 & 6.0 & 5.0 \\
\hline Retail price inflation (end of period) & 17.7 & 11.5 & 6.6 & 9.8 & 7.2 & 7.2 \\
\hline of which: Core inflation 6/ & 14.5 & 9.5 & 5.9 & 5.0 & 4.5 & 4.5 \\
\hline
\end{tabular}

Source: Serbian authorities; and Fund staff estimates and projections.

1/ Authorities' objectives at the time of the final review of the EA in Feb. 2006.

2/ Current policies (staff estimate).

3/ Staff-proposed policies.

4/ On IMF accounting methodology, which excludes one-off telecom licenses and includes repayment of debts to pensioners.

5/ Corrected for the impact of the VAT introduction in 2005. Excluding grants.

$6 /$ In 2008, middle of the 3-6 percent target range.

sustainability, while allowing a relaxation in the outer years - assuming that strong structural measures are taken. Absent those, fiscal adjustment would have to be sustained longer.

\section{The government saw current fiscal and structural policies as sufficient to} address external imbalances, while calling on monetary policy to be more supportive of external concerns. The government favored a more gradual fiscal adjustment strategygiven favorable financing conditions, policies inherited from the previous government, and the still unsettled political situation. In particular, it saw room to use privatization proceeds to increase much-needed public investment. The government underscored its resolve to accelerate privatization of socially owned enterprises, but noted that it needed time to develop a reform strategy for large state-owned enterprises. Finally, while acknowledging the NBS' success in bringing down inflation, the government saw room for intervention to avoid nominal exchange rate appreciation and, thereby, support exports.

\section{Fiscal Policy}

\section{While the authorities considered that they were making strong efforts to curb} discretionary spending, the $\mathbf{2 0 0 8}$ fiscal stance is expected to turn out expansionary. The budget information provided to staff implied a larger general government deficit in 2008 than the expected 2007 outcome, despite cuts relative to the budget. Staff warned that with large increases in the wage bill (mostly the result of carry-over wage hikes from 2007), hefty 
pension benefit increases, and continued high NIP spending, fiscal policy would further fuel domestic demand and widen external imbalances. ${ }^{11}$ The authorities emphasized that much of the budget was predetermined by past wage increases and existing pension commitments, and that reneging on those would weaken trust in government institutions.

\section{To help contain domestic demand, staff} recommended a fiscal surplus in 2008 . Reducing external imbalances would require sizeable fiscal surpluses of 2-3 percent of GDP until the benefits of structural reforms are reaped. Staff saw a rapid move to such surpluses as essential to ensuring external stability, and recommended that the budget target a surplus of 1 percent of GDP already in 2008. Experiences from other emerging European countries show that such fiscal adjustment is feasible.

\section{There was broad agreement that} expenditure rationalization was key. Staff emphasized that fiscal consolidation should focus on expenditure control, in particular on stronger wage control (both for the general government and public enterprises) and better prioritization of the capital budget, subsidies, and other current spending. Pension benefits should be indexed to price inflation only. Over the medium term, these measures would be supported by broader civil service and pension reforms. The authorities agreed that there was room to strengthen investment planning under the NIP and in the planned public-private partnerships, and noted that they had started to formulate an investment strategy.

\section{Staff discussed the authorities' plans for restitution of assets confiscated after}

World War II. Staff cautioned that the currently contemplated ceiling of $€ 4$ billion (over 10 percent of GDP) would, in the absence of compensating measures, significantly deteriorate the fiscal position (Appendix II). In case of compensation through bonds, staff deemed dinar denomination appropriate given the domestic nature of the assets, and a way to limit government's foreign exchange exposure.

\section{Monetary and Exchange Rate Policies}

\section{Staff recommended continuing on the path towards full-fledged inflation}

targeting. The NBS has achieved notable progress in bringing down inflation, establishing

\footnotetext{
${ }^{11}$ The pension increase stemmed from a provision, valid until 2008, setting a floor on the ratio of the average pension nationwide to the average wage.
} 
the repo interest rate as the benchmark for dinar markets, and improving capacity in modeling and forecasting inflation, foreign exchange operations, and communication. ${ }^{12}$ Nevertheless, formal adoption of inflation targeting would be premature since key prerequisites - explicit government support and sound fiscal policies - were not yet in place.

27. Staff and the authorities agreed that the real exchange rate was likely overvalued, but views on the appropriate policy response varied. Staff urged resisting calls on the central bank to stem dinar appreciation through active foreign exchange intervention. The government supported such call, noting that the strengthening of the dinar had aggravated external pressures and led to sizeable operating losses for the NBS. Staff emphasized that competitiveness problems should be addressed at their roots through fiscal consolidation and strengthened structural policies. Staff also pointed out that active interventions could - given high euroization - undermine the central bank's inflation objectives, as well as the repo rate as the main policy instrument. Thus, it urged maintaining exchange rate flexibility and limiting interventions to smoothing shocks, while using the available scope for a more accommodative monetary stance in case the inflation target was undershot.

28. There was broad agreement that although the inflation objectives should not be compromised, monetary policy should accommodate price level convergence. It was agreed that the NBS should aim at the middle of the 3-6 percent core inflation target range for end-2008. In determining the degree of ambition in longer-term objectives, the NBS should balance the desire to further lower inflation and the need for structural convergence of prices during transition.

\section{E. Structural Policy}

29. Staff and the authorities agreed that reforming the corporate sector is the only way to achieve durable growth, and should be accelerated. Wide-ranging privatization and restructuring is needed to reduce financial losses in the state- and socially owned corporate sector, thereby laying the ground for stronger growth, exports, and employment. Progress was mixed, however.

30. The authorities pointed to a significant acceleration of the privatization program of socially owned enterprises. Since the summer, the number of companies offered for sale has increased significantly, and proposed amendments to the privatization law are expected to facilitate the sale or liquidation of the remaining ones by end-2008. Moreover, resolution of the most difficult cases is under way, including through bankruptcies. Staff welcomed

\footnotetext{
${ }^{12}$ Selected Issues Chapter VI presents a simple applied model of monetary policy analysis.
} 
these developments and supported strengthening of the bankruptcy framework along with stepped-up initiation of bankruptcies through public authorities where appropriate.

\section{But there was less clarity on state-owned enterprises and utilities. The} government was discussing an ambitious plan to sell a part or a majority stake in the stateowned oil conglomerate and in the national airline, and to launch minority IPOs for the electricity, telecom, airport, and pharmaceutical companies. While staff welcomed these initiatives following stalled reforms over the past year, it regretted the apparent lack of consensus within the governing coalition on these privatization plans, and encouraged rapid progress - the only way to modernize and ensure the viability of these companies.

\section{There was broad recognition of the need to further improve the business}

environment. This involved stepping up efforts to review and streamline a wide range of legislation and regulations - which the authorities indicated they were preparing.

\section{F. Financial Sector Policy}

\section{There was broad agreement that the NBS' tight macro-prudential stance is} appropriate, notwithstanding some distortions created within the financial system. The tight macro-prudential stance is justified by the need to ensure that substantial capital cushions the banking system's vulnerabilities - partly manifested in rapid growth of household non-performing loans - due to rapid credit expansion. Moreover, high euroization and expansionary fiscal policies leave few alternative tools for curbing credit growth. It was acknowledged, however, that high reserve requirements prompted some disintermediation through increased cross-border borrowing. Nevertheless, it was agreed that macro-prudential policies should remain restrictive until vulnerabilities subside.

\section{At the same time, staff urged a greater balance between tightening regulations} and enhancing cross-border supervisory coordination. The authorities pointed to intensified consultation with banks and progress in signing Memoranda of Understanding (MoUs) with foreign supervisors. But there was agreement that more could be done to formalize coordination and improve the information flow.

\section{A strategy for developing Serbian capital markets is needed to help diversify the} financial system and contribute to greater stability. Currently, liquidity in the stock market is shallow and domestic bond markets are largely inexistent. A benchmark government yield curve would allow banks to better price dinar products with longer maturities, paving the way for reduced foreign exchange borrowing. It would also strengthen the effectiveness of the repo rate in monetary transmission, foster growth of the domestic institutional investor base, and increase private savings. The authorities were working on a strategy for capital market development, expected to be completed in 2008. 
36. In light of the recent turmoil in international financial markets, staff and the authorities agreed on the importance of increased vigilance going forward. To safeguard financial stability, staff underscored the need to continue strengthening the regulatory and supervisory framework and to monitor banks' risk management and resilience to shocks. The authorities cited the work of the NBS' new financial stability unit. They acknowledged, however, that transition from a compliance-oriented regime to risk-based supervision was likely to be gradual.

\section{The authorities have implemented the recommendations of the 2005 FSAP and} are addressing remaining concerns. Regulations on consolidated supervision and implementation of IFRS standards were adopted. Of the two remaining large state-owned banks, one was sold last year and the other was opened to a strategic investor. In light of rapid market development and rising vulnerabilities, the authorities saw merits in an FSAP update.

\section{STAFF Appraisal}

38. Economic growth in Serbia has been strong but unbalanced. Growth at an estimated 7 percent in 2007 was impressive. While this was in part the welcome result of structural reforms and privatization of the past, it also reflected high domestic demand fueled by large wage increases, credit growth, and expansionary fiscal policies of last year. Investment remains low, and with some of this short-term boost expected to wear out, growth is likely to decelerate.

39. Tight monetary policies have been successful in maintaining low inflation, but wage growth has not moderated correspondingly. Inflation has come down, despite recent supply shocks and rises in oil and other administered prices, and core inflation-which is targeted by the NBS - remained well within the target range. But real wage increases of 20-25 percent were clearly in excess of productivity growth.

40. In the meantime, vulnerabilities have increased. With excess demand translating into a rapid growth of imports, the current account deficit widened to 16 percent of GDP. Capital inflows continued, but less in the form of FDI and more as external borrowing, resulting in a rising external debt. Meanwhile, credit—mostly euroized - grew rapidly.

41. Under current policies, external imbalances will persist. The absence of a coordinated policy approach, if continued, would dampen growth prospects while fueling demand pressures. Thus, staff projects the current account deficit to remain large and external debt to rise rapidly. The presently unbalanced policy mix of loose fiscal, tight monetary, and until recently slow-moving structural policies is reflected in an overvalued real exchange rate, although the size of the overvaluation is uncertain. This and the capital account vulnerabilities raise concerns over external stability. 
42. Fiscal policy needs to be tightened significantly. Restrictive fiscal policy is the main short-term macroeconomic tool available to reduce external imbalances. Targeting a tight fiscal stance would help contain excess demand pressures and increase the likelihood of a turnaround in the current account. It would support monetary policy and create space to finance growth-enhancing infrastructure needs in the medium term.

43. However, the fiscal stance for 2008, as laid out in the latest budget document, is expansionary. Despite efforts in curbing discretionary spending, large public wage bill and pension increases coupled with continued high NIP spending will fuel a further widening of external imbalances.

44. To help contain domestic demand, fiscal surpluses are needed in the years to come, until the benefits of structural reforms are reaped. A quick move is essential and a surplus of 1 percent of GDP should be targeted already in 2008, followed by surpluses of 2-3 percent in 2009-10, until the impact of structural reforms on growth and exports fully materializes. Fiscal consolidation should focus on expenditure savings, in particular by controlling public sector wages and pension benefits, streamlining subsidies, and prioritizing capital spending.

45. Low inflation should be entrenched, including by eventual formal adoption of inflation targeting once government support and sound fiscal policies are in place. The NBS should aim at the middle of the 3-6 percent core inflation target range in 2008, balancing the objective of low inflation with the need for price convergence during transition.

46. Competitiveness should be restored through corporate restructuring and wage moderation rather than exchange rate policies. Attempts to inflate away the loss of competitiveness, which has its roots in excessive wage increases, slow structural reforms, and loose fiscal policies, would damage credibility while providing no sustained relief for exports. Staff supports exchange rate flexibility, with interventions limited to smoothing shocks.

47. Accelerating structural reforms is key, but will take time to bear fruit. Staff welcomes the renewed efforts to accelerate privatization or bankruptcy of socially owned enterprises and urges completion of the process as soon as possible. It supports opening the capital of state-owned utilities to private sector participation, including by selling majority stakes. Major efforts are needed to improve the business environment.

48. Financial stability risks have so far been managed by building adequate buffers. Rigorous prudential regulations were appropriate to address rapidly rising vulnerabilities. As a result, the banking sector is well capitalized. Notwithstanding concerns about circumvention, the prudential framework should remain restrictive until macro and financial vulnerabilities subside. The recent turbulence in international financial markets and increased 
volatility in Serbian markets due to political uncertainties underscore the need for stabilityoriented macro policies and contingency planning.

49. The supervisory framework should continue to be strengthened. Vulnerabilities stemming from rapid household credit growth are rising. Safeguarding financial stability requires continued close monitoring of banks' non-performing loans, risk management, and resilience to shocks. Further progress involves continuing to build capacity and strengthening the dialogue with banks and foreign supervisors. Developing capital markets will diversify the financial system and contribute to its stability.

50. Serbia's statistical data are broadly adequate for surveillance. Staff encourages the authorities to remove the remaining exchange restrictions. It is proposed that the next Article IV consultation be held on the standard 12-month cycle. 
Figure 1. Serbia and Selected Neighboring Countries: Indicators of Institutional Quality and Reform, 2007 (Rank, unless otherwise specified)
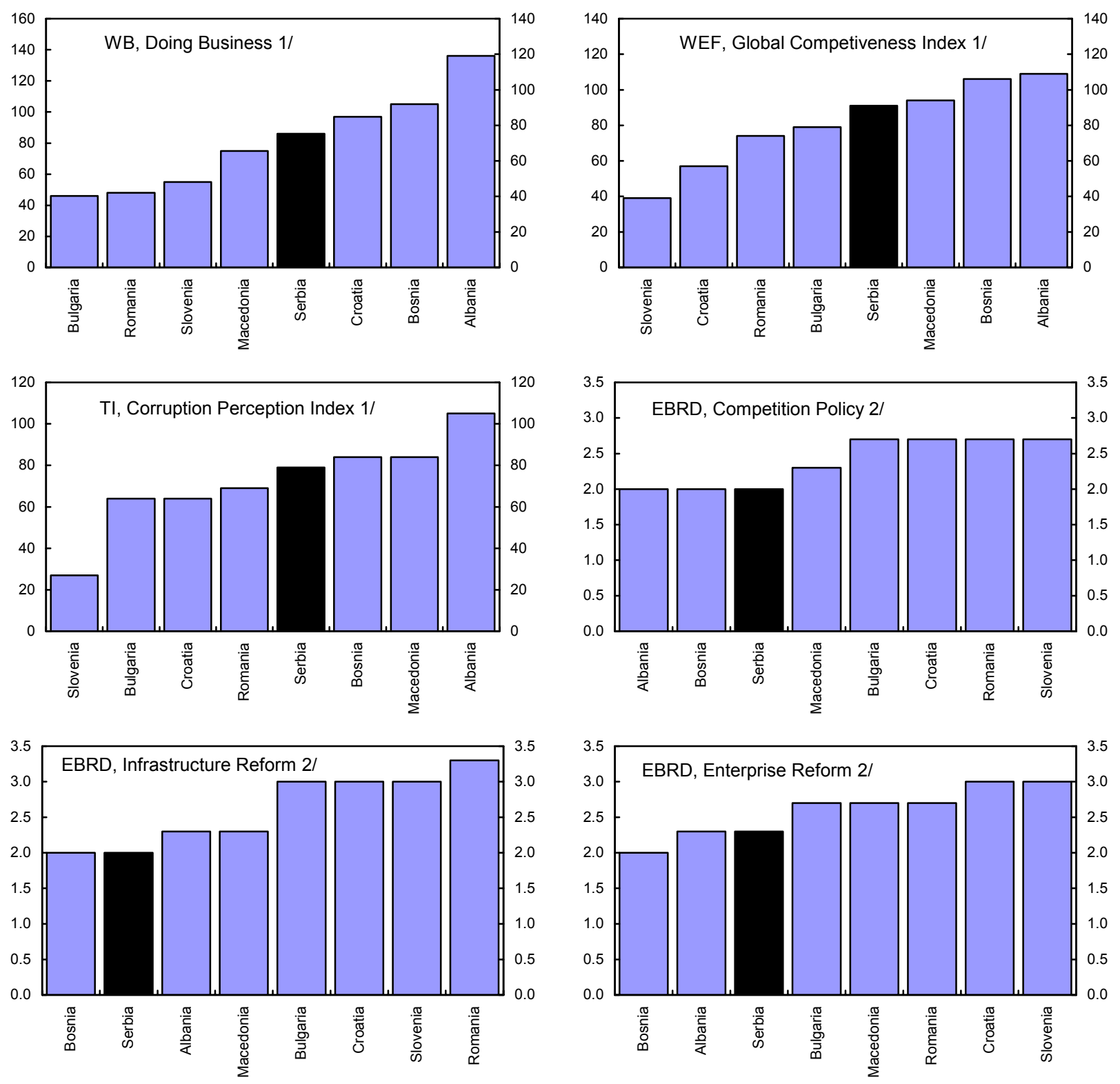

Sources: World Bank: Doing Business Database (WB); World Economic Forum (WEF); Transparency International (TI); and European Bank for Reconstruction and Development (EBRD).

1/ Lower ranking means better environment. The World Bank index cover 175 countries. The global competitiveness index covers 125 countries. The corruption index relates to perceptions of the degree of corruption as seen by business people and county analysts.

2/ Higher ranking means better environment. The EBRD maximum score is 4.33 . 
Figure 2. Serbia and Selected Neighboring Countries: External Balances and Growth, 2005-07 (In percent of GDP, unless otherwise indicated)
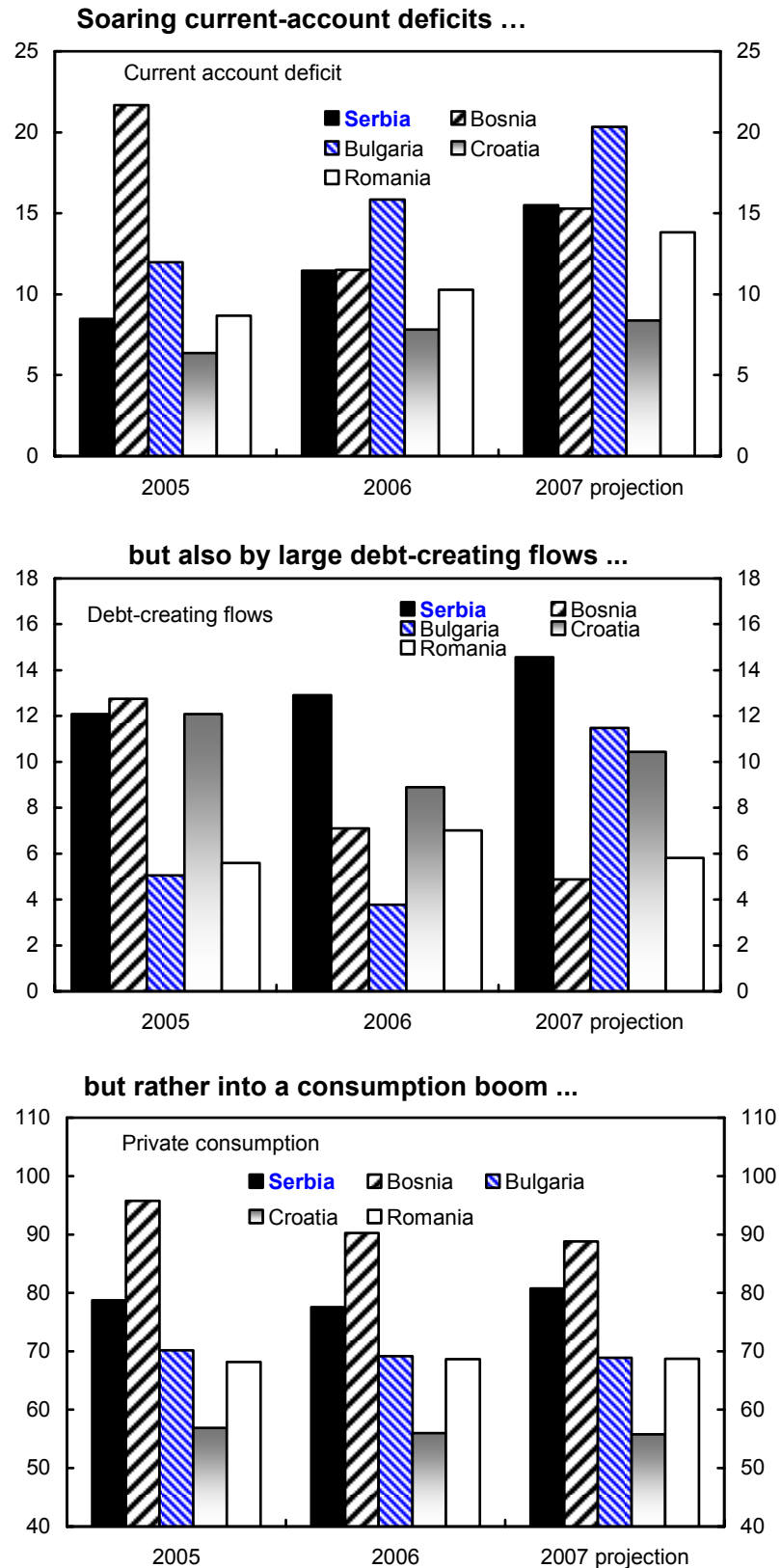

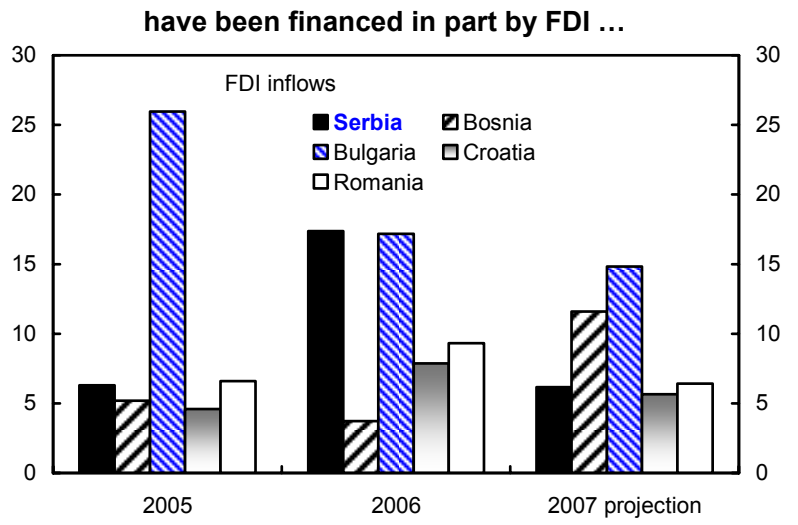

In Serbia, this did not translate into investment ...

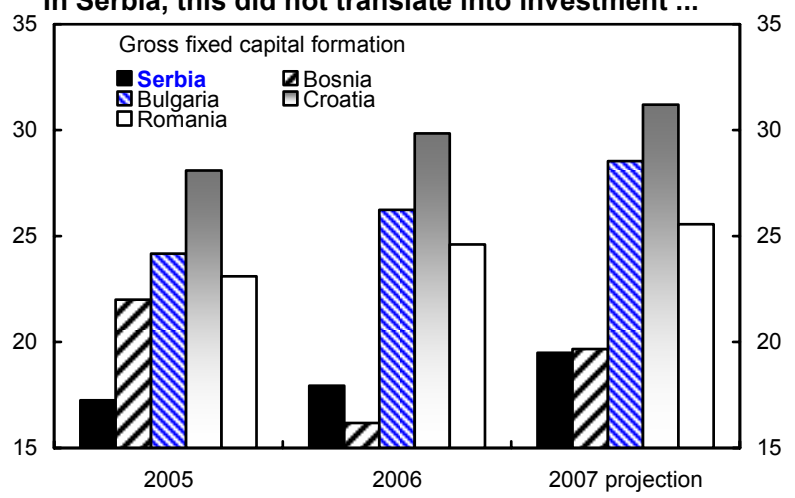

... while real GDP growth responded modestly.

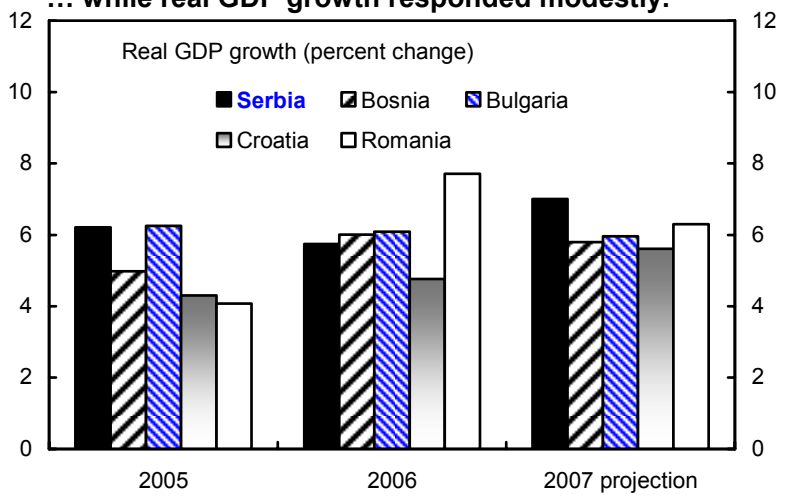


Figure 3. Serbia: Macroeconomic Indicators, 2002-07
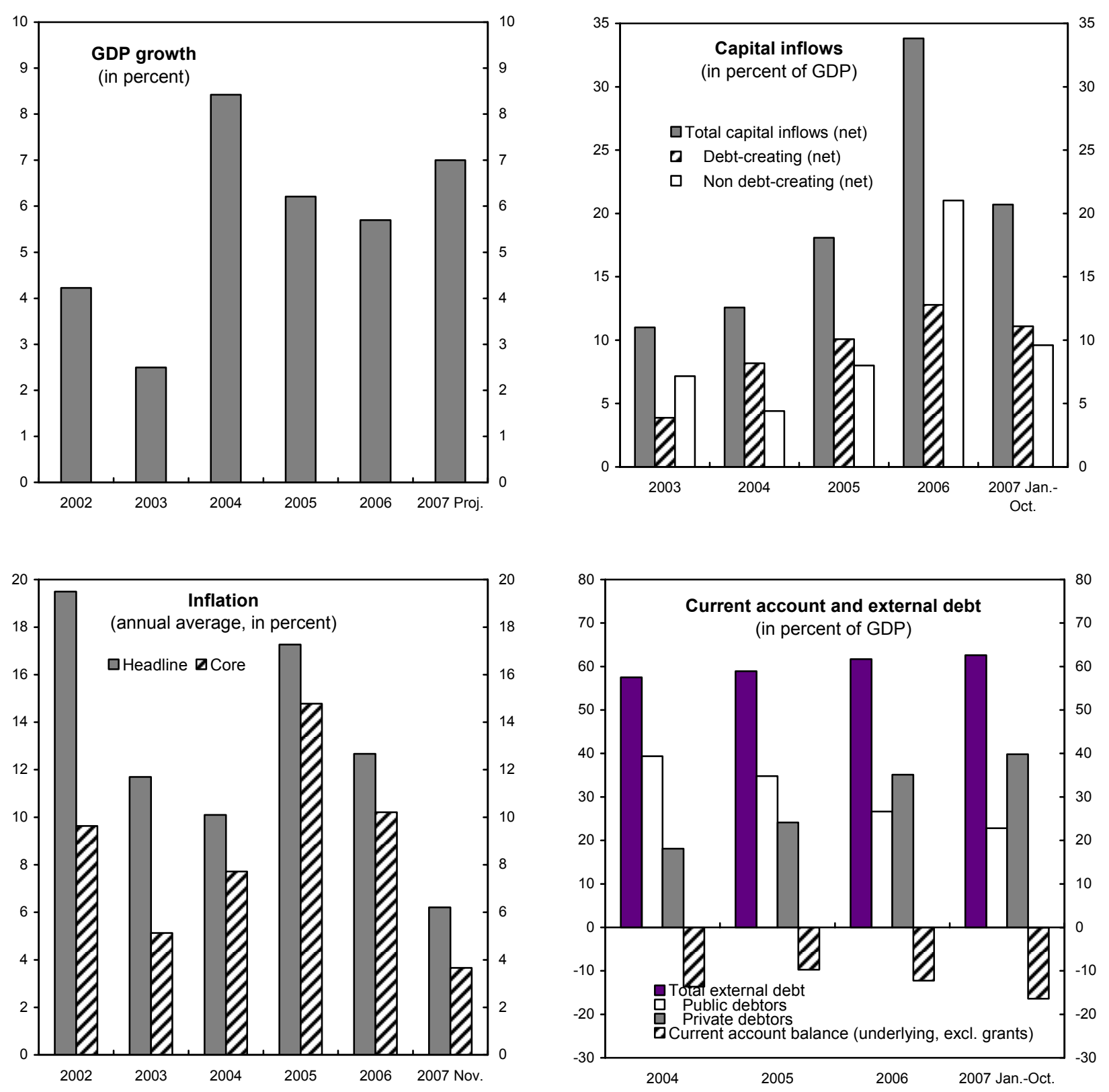

Sources: National Bank of Serbia, Serbian Statistics Office; and Fund staff estimates. 
Figure 4. Serbia: Economic and Financial Developments, 2005-07

(Quarterly Annualized Percentage Change, Seasonally Adjusted, Adjusted for VAT)
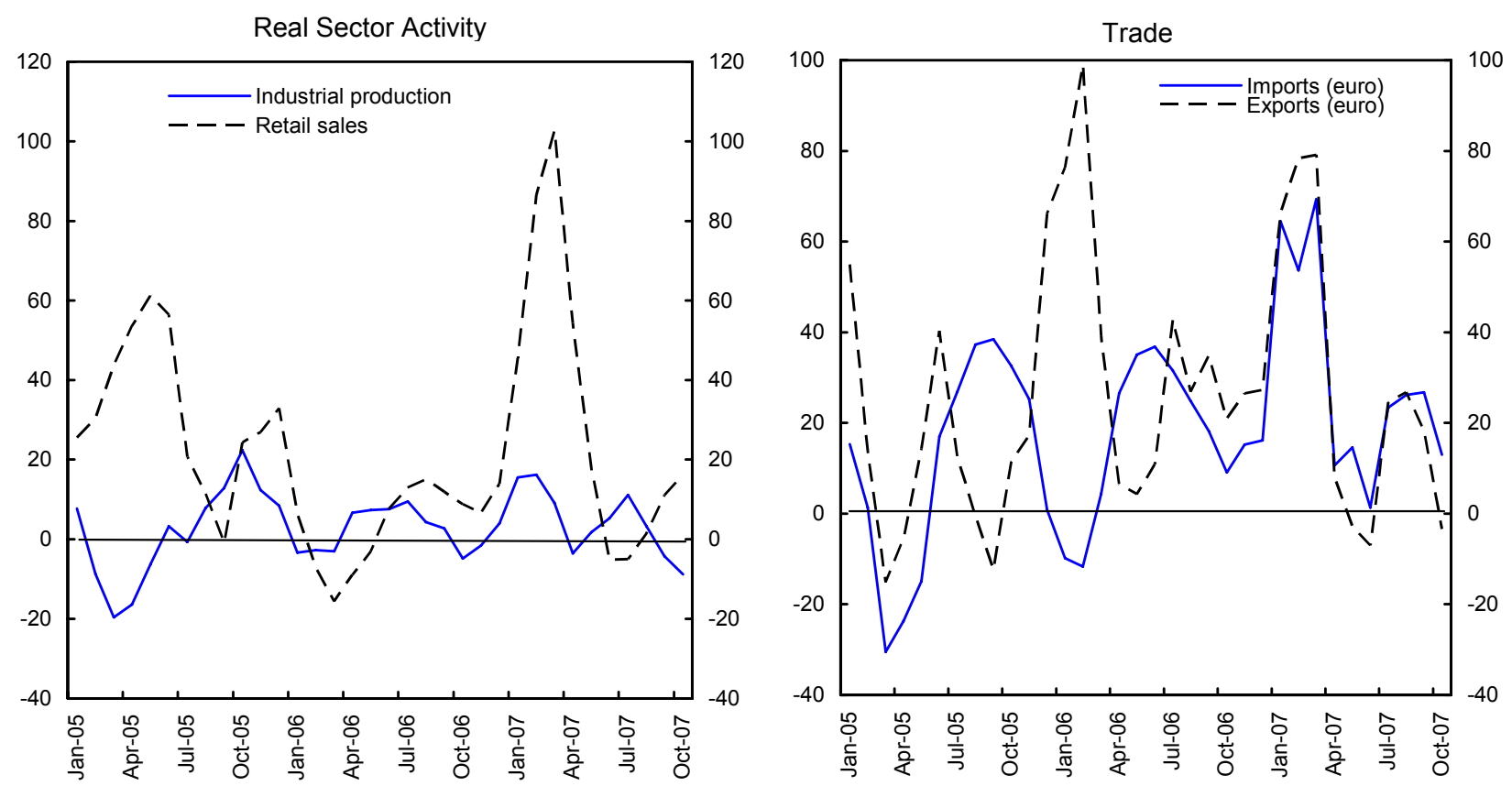

Flows of Net Credit to Non-Government Sector

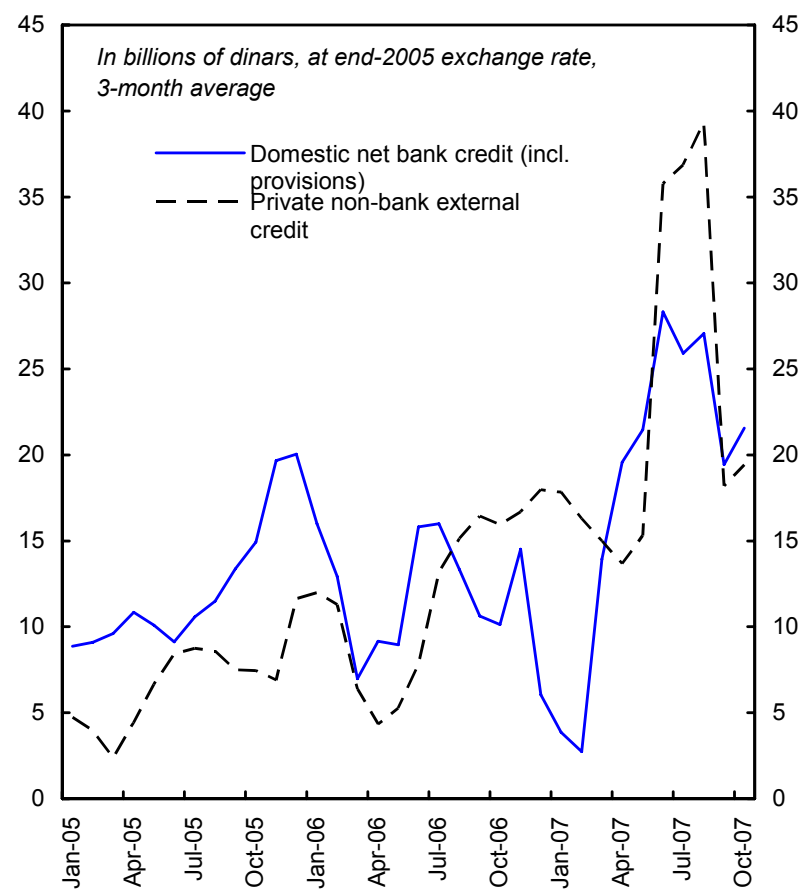

Inflation

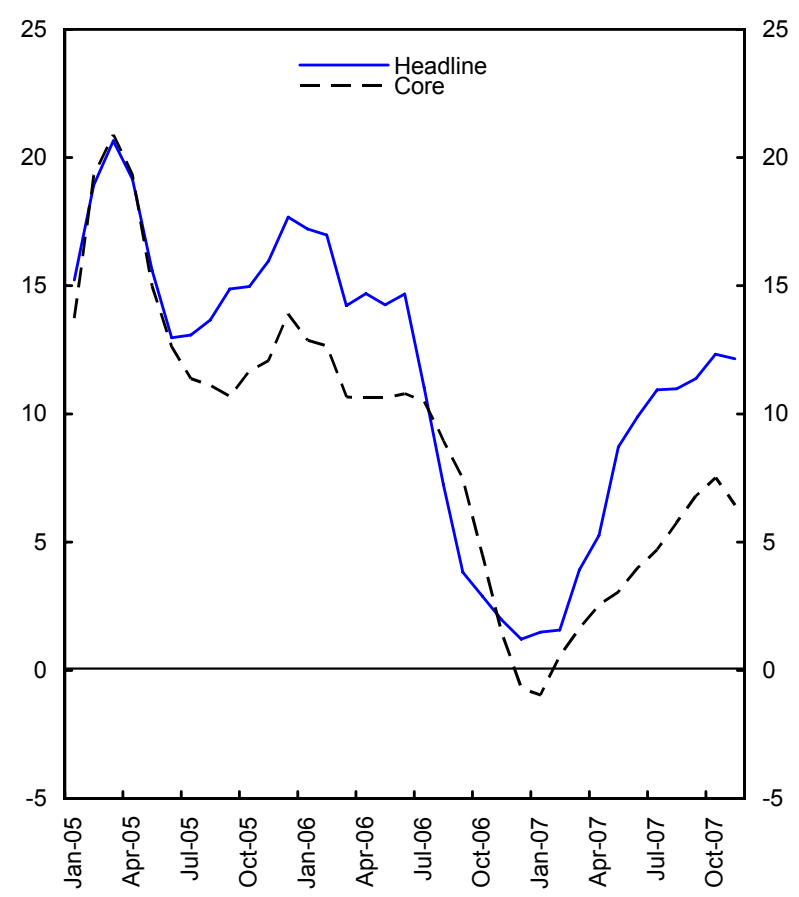

Sources: National Bank of Serbia, Serbian Statistics Office; and Fund staff estimates. 
Figure 5. Serbia: Competitiveness Indicators

(3-month moving average, s.a., annualized, unless otherwise noted)

Real wages, led by the public sector, rose sharply at end-2006 and early-2007.

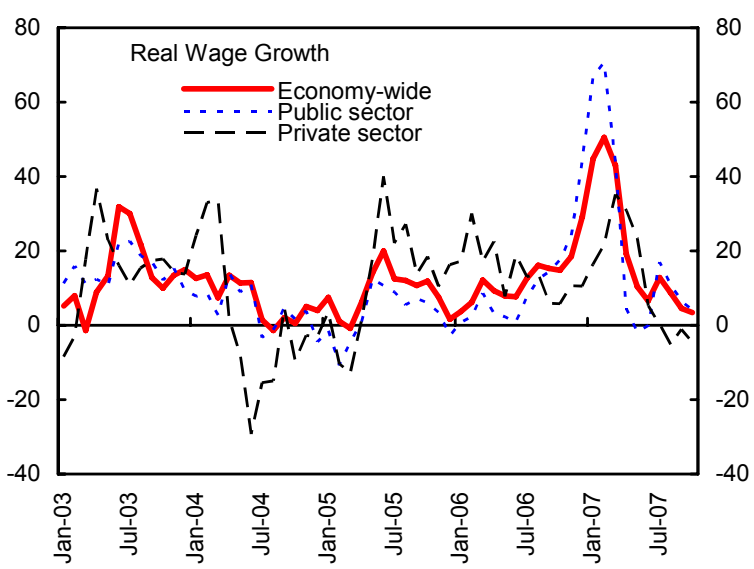

Thus, despite soaring wages in euro terms...

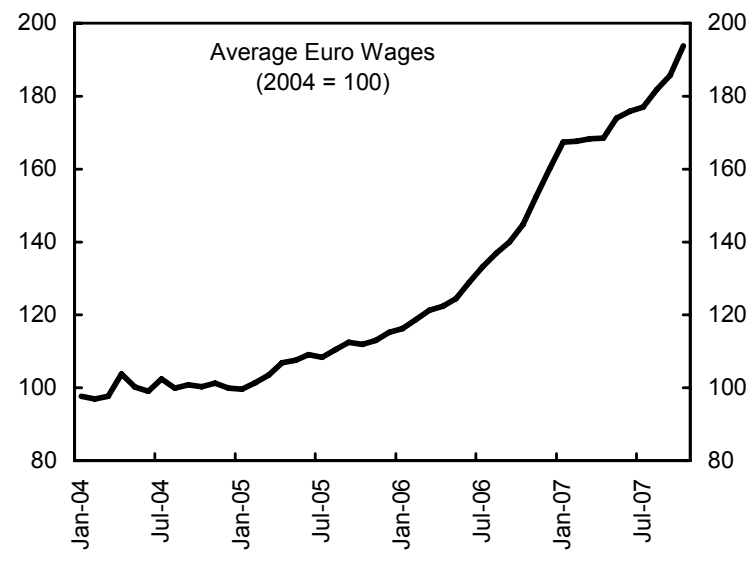

The REER_CPI appreciated significantly in Q2-Q3 2006 and in Q3 2007.

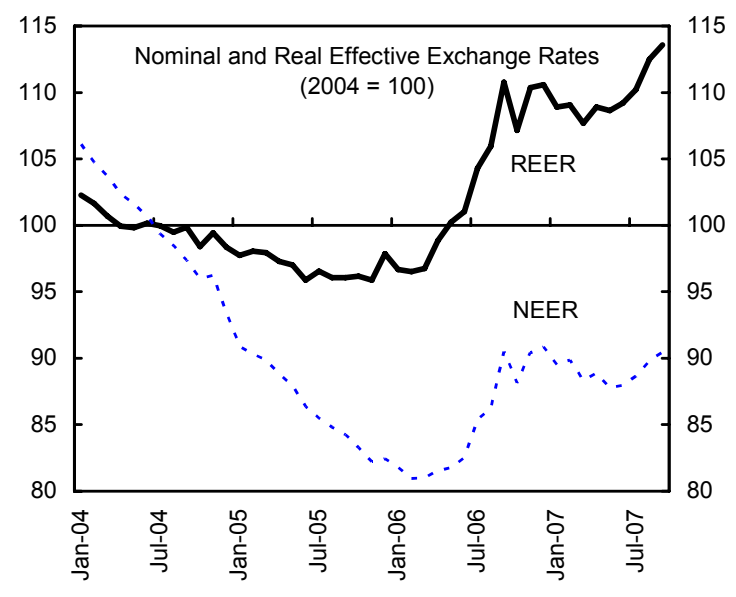

However, in industry, real wages hikes were broadly in line with productivity gains.

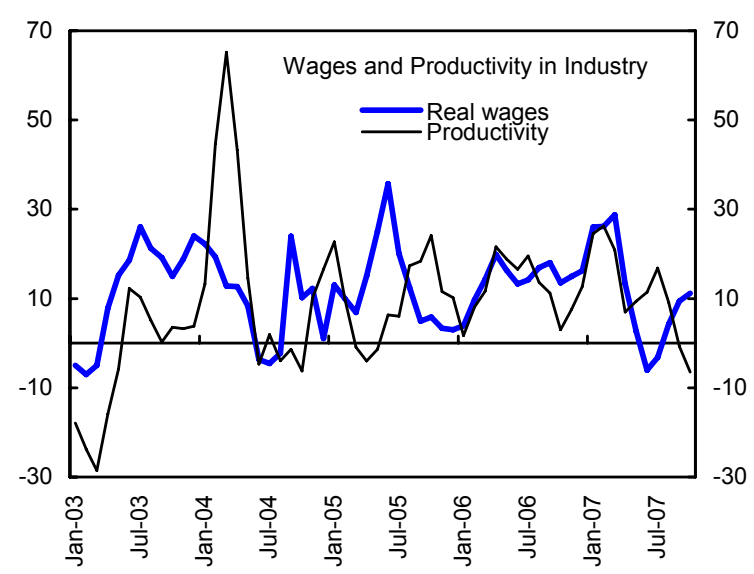

... euro unit labor costs eased somewhat in 2007 following the stabilization of the dinar.

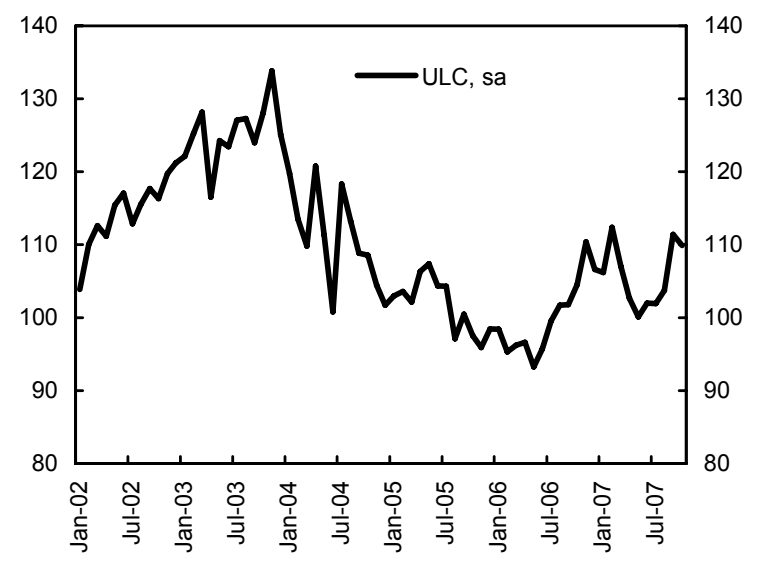

The REER rise led to some competitiveness losses for Serbia against its neighbors (except Romania).

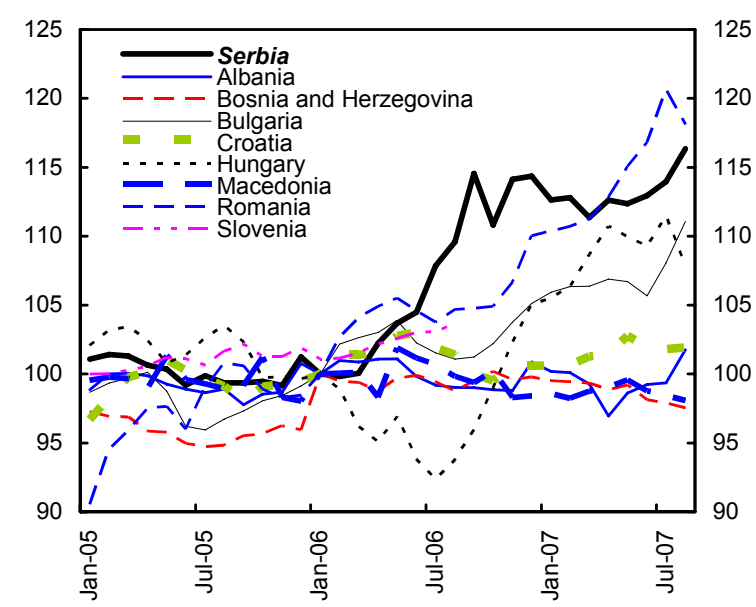

Sources: Serbian authorities; and staff estimates and projections. 
Figure 6. Emerging European Countries: Vulnerability Indicators, 2006
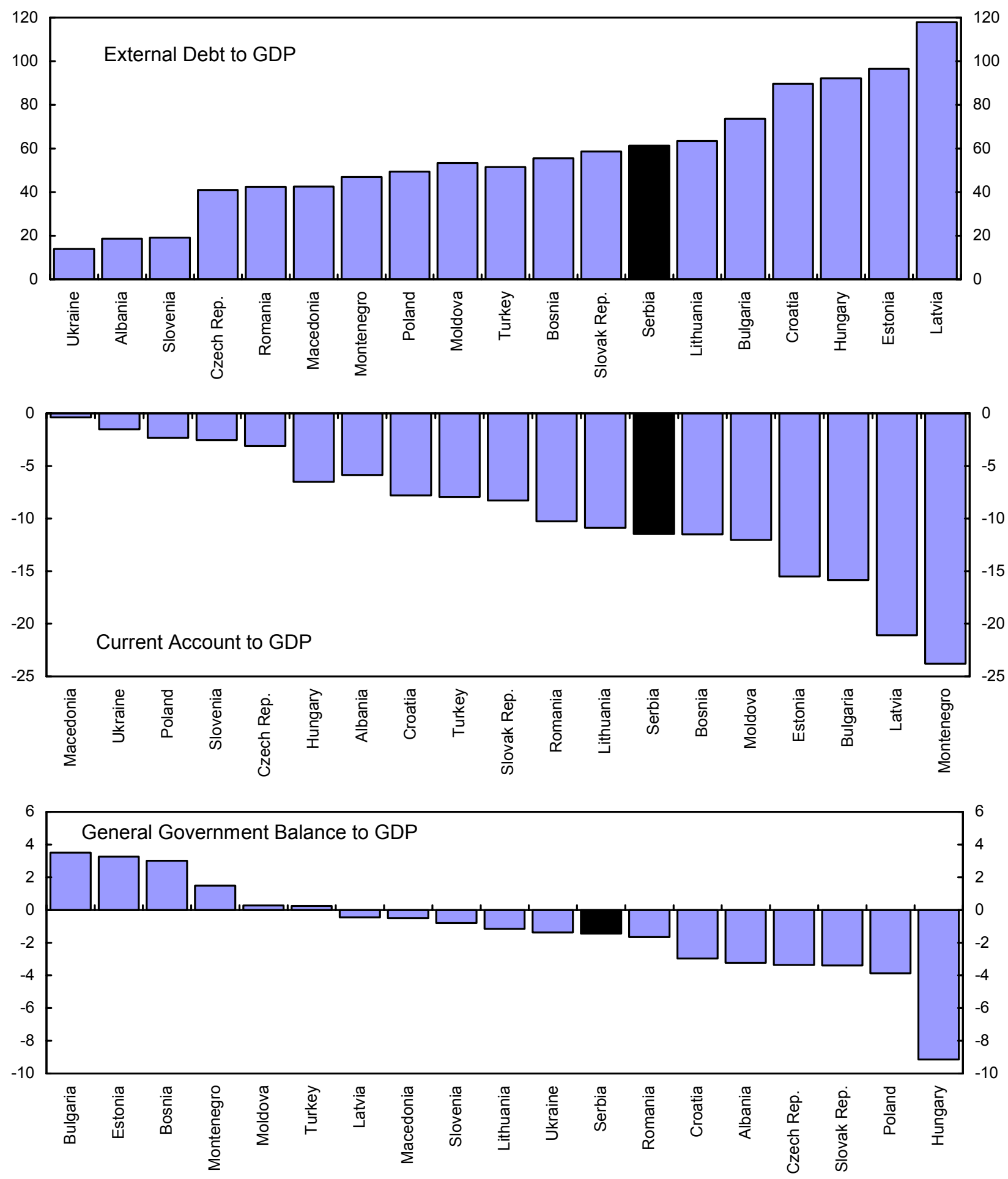

Source: WEO 
Figure 6. Emerging European Countries (Continued): Vulnerability Indicators, 2006
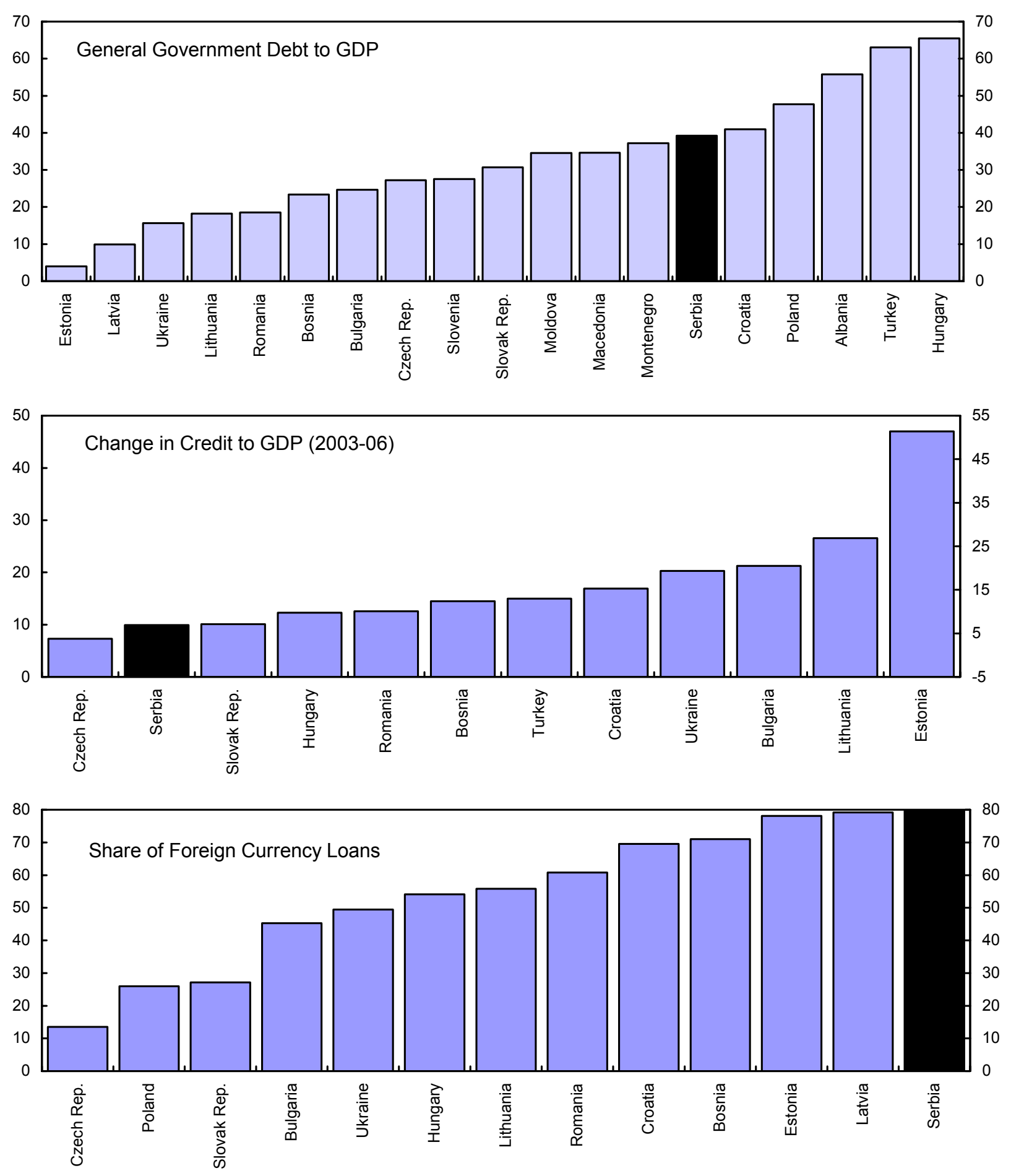

Source: WEO. 
Figure 7. Serbia: Medium-Term Scenarios, 2003-12

(In percent of GDP, unless otherwise indicated)

Stronger fiscal and structural policies...

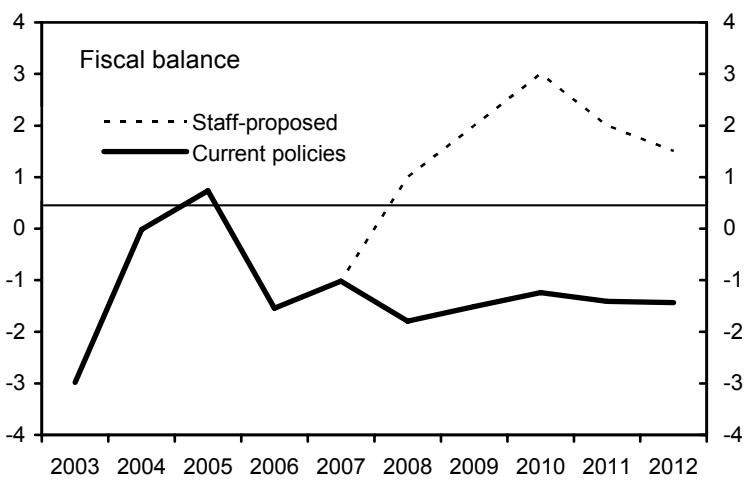

and alleviate excess demand and competitiveness pressures, ...

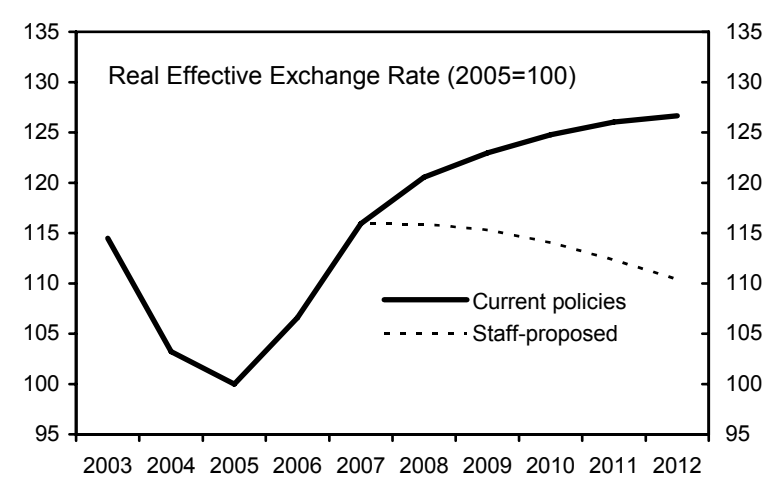

higher GDP growth, ...

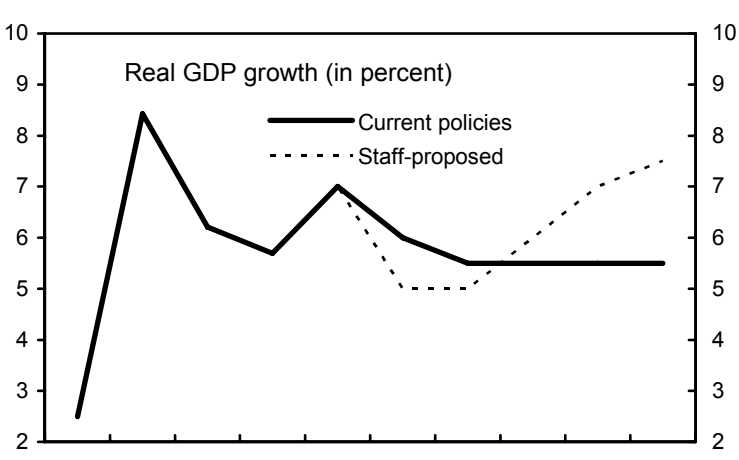

2003200420052006200720082009201020112012 would help attract foreign direct investment...

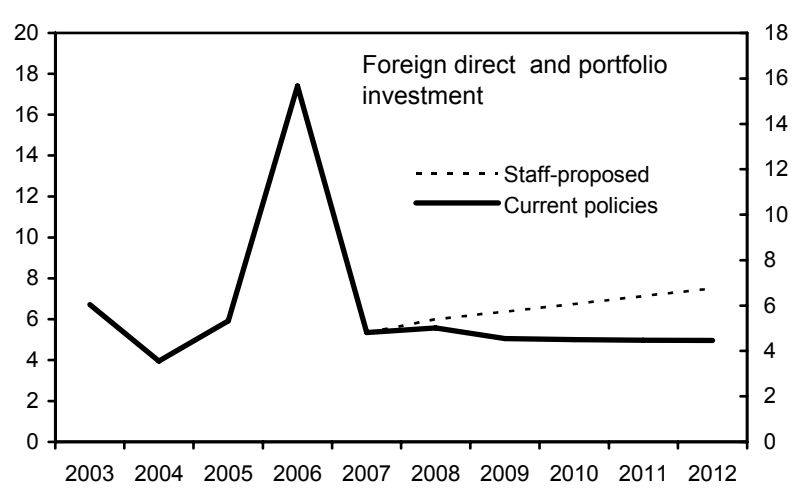

resulting in an improvement in the external current account, ...

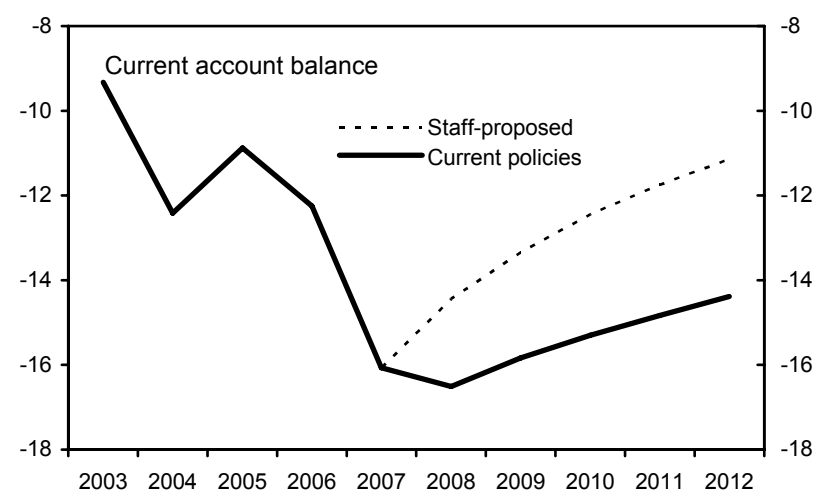

and a more sustainable path for external debt.

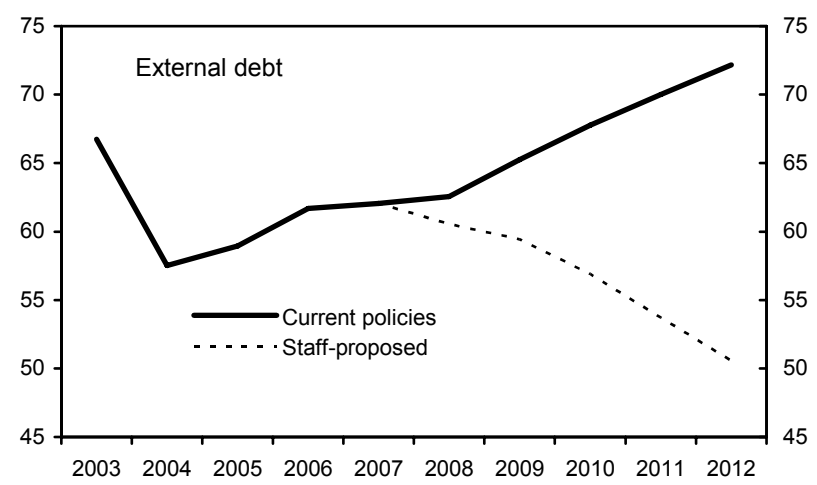

Sources: Serbian authorities; and IMF staff estimates and projections. 
Table 1. Serbia: Authorities' Response to Past Policy Recommendations

Advice from the 2006 Article IV Consultation

Response

\section{Fiscal policy}

Sizeable surpluses for the consolidated general government remain appropriate.

Critical public investments should be funded by efficiencies in current spending, rather than fiscal relaxation.

\section{Structural policy}

Acceleration of corporate restructuring and completion of the privatization of socially owned and state-owned companies are the central response.

Swift and consistent initiation of bankruptcy procedures is required.

Improvements in the business climate, increased flexibility of labor market institutions.

\section{Financial sector policy}

Strengthen banking supervision, including in regard to the exposure of unhedged borrowers to exchange rate risk.

Strengthen competition in the banking sector; consider issuing greenfield licenses.

\section{Monetary and exchange rate policy}

New monetary policy framework as an important step toward eventual full-fledged inflation targeting.

Scaling back foreign currency interventions to a "leaning against the wind" role, with increased exchange rate flexibility.
Fiscal deficits observed or planned in 2006-08.

In addition to fiscal relaxation, no drop in current expenditure (in percent of GDP) between 2005 and 2007.

Privatization of socially owned enterprises to be completed by end-2008. Privatization of stateowned enterprises stalled, but plans are now being prepared by the new government.

Only recent acceleration of bankruptcies.

Limited progress to date.

Regulations strengthened in 2006-07. Further measures aimed at tightening foreign exchange exposure to be introduced in 2008. Work on NPL data and financial stability analysis_-including stress tests-under way.

Reform efforts aimed at completing restructuring and privatization of the remaining state banks. No new greenfield licenses issued.

Continued progress in implementing the inflation targeting framework, with the repo rate maturing into the reference rate for dinar markets.

Limited foreign exchange interventions. Phasing out of purchases from foreign exchange bureaus by end-2007.

Public Information Notice for 2006 Article IV Consultation: http://www.imf.org/external/np/sec/pn/2006/pn06120.htm 
Table 2. Serbia: Selected Economic and Financial Indicators, 2002-08 ${ }^{1 /}$

\begin{tabular}{|c|c|c|c|c|c|c|c|}
\hline & 2002 & 2003 & 2004 & 2005 & 2006 & 2007 & 2008 \\
\hline & & & & & & \multicolumn{2}{|c|}{ Proj. } \\
\hline & \multicolumn{7}{|c|}{ (Change in percent, unless otherwise indicated) } \\
\hline \multicolumn{8}{|l|}{ Real economy } \\
\hline Real GDP & 4.2 & 2.5 & 8.4 & 6.2 & 5.7 & 7.0 & 6.0 \\
\hline Of which: Non-agriculture value added & 1.8 & 2.8 & 6.6 & 7.3 & 7.9 & 8.5 & 6.4 \\
\hline Industrial production (period average) & 2.7 & -3.0 & 7.1 & 0.8 & 5.3 & 6.0 & 5.5 \\
\hline Retail prices (period average) & 19.5 & 11.7 & 10.1 & 17.3 & 12.7 & 6.5 & 9.2 \\
\hline (end of period) & 14.8 & 7.6 & 13.7 & 17.7 & 6.6 & 9.8 & 7.2 \\
\hline Core retail prices (period average) $2 /$ & $\ldots$ & 5.1 & 7.7 & 14.8 & 10.2 & 3.8 & 6.1 \\
\hline (end of period) & $\ldots$ & 6.2 & 11.0 & 14.5 & 5.9 & 5.0 & 4.5 \\
\hline Real net wage (period average) & 25.7 & 13.7 & 10.6 & 6.5 & 10.9 & 20.6 & 12.6 \\
\hline Net wage in euro (period average) & 46.3 & 16.2 & 10.0 & 8.3 & 23.3 & 36.9 & $\ldots$ \\
\hline Unemployment rate (in percent) $3 /$ & $\ldots$ & 14.6 & 18.5 & 20.8 & 20.9 & $\ldots$ & $\ldots$ \\
\hline GDP per capita (U.S. dollars) & 2,111 & 2,719 & 3,285 & 3,512 & 4,245 & 5,423 & 6,168 \\
\hline \multirow[t]{2}{*}{ Nominal GDP (in billions of dinars) } & $1,020.1$ & $1,171.6$ & $1,431.3$ & $1,750.5$ & $2,125.8$ & $2,423.0$ & $\ldots$ \\
\hline & \multicolumn{7}{|c|}{ (In percent of GDP) } \\
\hline \multicolumn{8}{|l|}{ General government finances } \\
\hline Revenue (excl. grants) & 39.5 & 40.7 & 41.4 & 41.3 & 40.7 & 41.3 & 41.2 \\
\hline Expenditure & 43.7 & 43.7 & 41.4 & 40.6 & 42.3 & 42.3 & 43.0 \\
\hline Overall balance (cash basis, excl. grants) & -4.2 & -3.0 & 0.0 & 0.7 & -1.5 & -1.0 & -1.8 \\
\hline of which: Primary balance (excl. interest) & & -2.0 & 1.2 & 2.2 & -0.1 & -0.1 & -1.0 \\
\hline Gross debt & 77.4 & 74.7 & 63.1 & 54.1 & 39.6 & 37.6 & 34.5 \\
\hline \multirow[t]{2}{*}{ of which: Forex-denominated (in percent of total) } & 88.9 & 87.7 & 85.7 & 90.8 & 89.5 & 87.6 & 85.8 \\
\hline & \multicolumn{7}{|c|}{ (12-month change, in percent) } \\
\hline \multicolumn{8}{|l|}{ Monetary sector (end of period) } \\
\hline Money (M1) & 79.8 & 10.9 & 8.0 & 30.9 & 37.1 & 35.0 & $\ldots$ \\
\hline Broad money (M2) 4/ & 52.7 & 27.5 & 30.3 & 43.2 & 39.8 & 42.0 & $\ldots$ \\
\hline \multirow[t]{2}{*}{ Credit to non-government } & 62.6 & 25.1 & 52.1 & 57.0 & 27.5 & 40.0 & $\ldots$ \\
\hline & \multicolumn{7}{|c|}{ (In percent) } \\
\hline \multicolumn{8}{|l|}{ Interest rates (weighted average, end of period) } \\
\hline NBS bills / Repo rate & 9.7 & 10.6 & 16.3 & 19.2 & 14.0 & 9.5 & $\ldots$ \\
\hline \multirow[t]{2}{*}{ Deposit rate } & 2.6 & 2.7 & 3.6 & 3.7 & 5.1 & 4.4 & $\ldots$ \\
\hline & \multicolumn{7}{|c|}{ (In percent of GDP, unless otherwise indicated) } \\
\hline \multicolumn{8}{|l|}{ Balance of payments } \\
\hline Current account balance, before grants & -11.0 & -9.3 & -13.6 & -9.7 & -12.2 & -16.1 & -16.5 \\
\hline Current account balance, adjusted $5 /$ & -11.0 & -9.3 & -12.4 & -10.9 & -12.2 & -16.1 & -16.5 \\
\hline Exports of goods (f.o.b.) & 14.0 & 16.3 & 16.6 & 18.9 & 20.4 & 21.4 & 21.3 \\
\hline Imports of goods (f.o.b.) & 34.4 & 36.1 & 43.0 & 39.1 & 40.0 & 42.1 & 42.9 \\
\hline Trade balance & -20.4 & -19.8 & -26.4 & -20.2 & -19.6 & -20.7 & -21.6 \\
\hline Remittances, net & 9.0 & 10.1 & 12.9 & 11.7 & 8.8 & 6.2 & 7.1 \\
\hline Current account balance, after grants & -7.9 & -7.0 & -11.7 & -8.5 & -11.5 & -15.5 & -15.9 \\
\hline FDI, portfolio investment, and capital transfers (net) & 3.0 & 5.9 & 3.8 & 5.9 & 17.4 & 5.3 & 5.6 \\
\hline Foreign loans, net & 5.3 & 3.9 & 8.2 & 10.1 & 12.8 & 13.9 & 8.2 \\
\hline External debt (end of period; billions of U.S. dollars) & 11.2 & 13.6 & 14.1 & 15.5 & 19.6 & 25.3 & 29.1 \\
\hline (In percent of GDP) & 70.9 & 66.7 & 57.5 & 58.9 & 61.7 & 62.0 & 62.6 \\
\hline of which: Private external debt & $\ldots$ & $\ldots$ & 18.1 & 24.1 & 35.1 & 41.4 & 44.1 \\
\hline Gross official reserves (in billions of U.S. dollars) & 2.3 & 3.6 & 4.2 & 5.8 & 11.9 & 14.6 & 14.6 \\
\hline (In months of prospective imports of GNFS) & 3.3 & 3.6 & 4.3 & 4.7 & 7.1 & 7.5 & 6.8 \\
\hline Exchange rate (dinar/euro, period average) & 60.7 & 65.1 & 72.6 & 82.9 & 84.2 & 80.2 & $\ldots$ \\
\hline \multicolumn{8}{|l|}{ REER (annual average change, in percent; } \\
\hline+ indicates appreciation) & 14.9 & 5.2 & -3.6 & -3.1 & 6.6 & 8.8 & 4.0 \\
\hline
\end{tabular}

Sources: Serbian authorities; and Fund staff estimates and projections.

1/ Excluding Kosovo (with the exception of external debt).

2/ The 2008 projection reflects the middle of the pre-announced target range of 3-6 percent.

3/ Eurostat/ILO-consistent from 2004.

4/ Excluding frozen foreign currency deposits.

5/ Corrected for the surge in imports and remittances ahead of the VAT introduction in 2005. 
Table 3. Serbia: Macroeconomic Framework, 2003-12 1/

\begin{tabular}{|c|c|c|c|c|c|c|c|c|c|c|}
\hline & 2003 & 2004 & 2005 & 2006 & 2007 & 2008 & 2009 & 2010 & 2011 & 2012 \\
\hline & & & & Est. & \multicolumn{6}{|c|}{ Proj. } \\
\hline \multicolumn{11}{|c|}{ (Annual change, in percent) } \\
\hline Gross domestic product (real) & 2.5 & 8.4 & 6.2 & 5.7 & 7.0 & 6.0 & 5.5 & 5.5 & 5.5 & 5.5 \\
\hline Retail prices (end-period) & 7.6 & 13.7 & 17.7 & 6.6 & 9.8 & 7.2 & 6.0 & 5.0 & 4.0 & 4.0 \\
\hline \multicolumn{11}{|c|}{ (Contribution to real GDP growth, in percent) } \\
\hline Domestic demand & 2.1 & 13.6 & 0.7 & 5.4 & 12.4 & 8.5 & 8.3 & 7.5 & 7.3 & 6.9 \\
\hline Consumption & -3.8 & 10.2 & 2.5 & 3.2 & 11.0 & 6.7 & 6.8 & 5.9 & 5.7 & 5.3 \\
\hline Non-government consumption & -4.3 & 12.1 & 3.8 & 3.4 & 9.9 & 6.4 & 6.4 & 5.6 & 5.3 & 4.9 \\
\hline Government consumption & 0.5 & -1.9 & -1.3 & -0.2 & 1.1 & 0.2 & 0.4 & 0.4 & 0.4 & 0.4 \\
\hline Gross fixed capital formation & 4.7 & 3.4 & 0.3 & 1.4 & 1.9 & 1.7 & 1.3 & 1.4 & 1.4 & 1.5 \\
\hline Net exports of goods and services & 0.4 & -5.2 & 5.6 & 0.3 & -5.4 & -2.5 & -2.8 & -2.0 & -1.8 & -1.4 \\
\hline \multicolumn{11}{|c|}{ (In percent of GDP) } \\
\hline Domestic demand & 118.8 & 123.6 & 122.1 & 119.8 & 120.7 & 121.5 & 121.7 & 121.3 & 121.0 & 120.6 \\
\hline Consumption & 96.1 & 99.9 & 101.1 & 97.9 & 98.8 & 98.8 & 98.6 & 97.9 & 97.1 & 96.3 \\
\hline Non-government & 73.6 & 80.1 & 83.3 & 80.8 & 80.9 & 81.3 & 81.1 & 80.4 & 79.6 & 78.8 \\
\hline Government & 22.5 & 19.8 & 17.9 & 17.1 & 17.8 & 17.5 & 17.5 & 17.5 & 17.5 & 17.5 \\
\hline Gross domestic savings & 3.9 & 0.1 & -1.1 & 2.1 & 1.2 & 1.2 & 1.4 & 2.1 & 2.9 & 3.7 \\
\hline Non-government & 3.9 & -2.8 & -5.1 & -0.9 & -2.4 & -2.5 & -2.6 & -2.0 & -1.1 & -0.2 \\
\hline Government & 0.0 & 3.0 & 3.9 & 3.0 & 3.7 & 3.7 & 3.9 & 4.2 & 4.0 & 3.9 \\
\hline Net factor receipts and transfers from abroad & 11.8 & 13.2 & 12.5 & 8.3 & 5.2 & 5.6 & 6.4 & 6.6 & 6.7 & 6.8 \\
\hline Non-government & 12.4 & 13.9 & 13.2 & 9.0 & 5.8 & 6.1 & 6.9 & 7.0 & 7.1 & 7.2 \\
\hline Government & -0.6 & -0.8 & -0.8 & -0.7 & -0.6 & -0.5 & -0.5 & -0.5 & -0.4 & -0.4 \\
\hline Gross national savings & 15.7 & 13.3 & 11.3 & 10.4 & 6.5 & 6.7 & 7.8 & 8.7 & 9.6 & 10.5 \\
\hline Non-government & 16.2 & 11.1 & 8.2 & 8.1 & 3.3 & 3.5 & 4.3 & 5.0 & 6.0 & 7.0 \\
\hline Government & -0.5 & 2.2 & 3.2 & 2.3 & 3.1 & 3.2 & 3.4 & 3.7 & 3.5 & 3.5 \\
\hline Gross domestic investment 2/ & 22.7 & 23.7 & 20.9 & 21.9 & 22.0 & 22.6 & 23.0 & 23.4 & 23.9 & 24.3 \\
\hline Of which: Gross fixed capital formation & 16.1 & 17.7 & 17.3 & 17.6 & 18.4 & 19.1 & 19.5 & 19.9 & 20.3 & 20.7 \\
\hline Non-government & 20.3 & 21.2 & 18.4 & 18.1 & 17.8 & 18.1 & 18.5 & 18.9 & 19.4 & 19.8 \\
\hline Gross fixed capital formation & 13.7 & 15.2 & 14.7 & 13.8 & 14.2 & 14.6 & 15.0 & 15.4 & 15.8 & 16.2 \\
\hline Change in inventories & 6.6 & 6.0 & 3.7 & 4.3 & 3.6 & 3.6 & 3.6 & 3.6 & 3.6 & 3.6 \\
\hline Government & 2.4 & 2.5 & 2.6 & 3.8 & 4.2 & 4.5 & 4.5 & 4.5 & 4.5 & 4.5 \\
\hline Savings-investment balance & -7.0 & -10.5 & -9.6 & -11.5 & -15.5 & -15.9 & -15.3 & -14.7 & -14.3 & -13.8 \\
\hline Non-government & -4.0 & -10.2 & -10.2 & -10.0 & -14.4 & -14.6 & -14.2 & -13.9 & -13.3 & -12.8 \\
\hline Government & -2.9 & -0.3 & 0.6 & -1.5 & -1.1 & -1.3 & -1.1 & -0.8 & -1.0 & -1.0 \\
\hline Foreign savings $1 /$ & 7.0 & 10.5 & 9.6 & 11.5 & 15.5 & 15.9 & 15.3 & 14.7 & 14.3 & 13.8 \\
\hline Foreign savings excluding official grants $1 /$ & 9.3 & 12.4 & 10.9 & 12.2 & 16.1 & 16.5 & 15.8 & 15.3 & 14.8 & 14.4 \\
\hline \multicolumn{11}{|l|}{ Memorandum items: } \\
\hline Net exports of goods and services $3 /$ & -18.8 & -23.6 & -22.1 & -19.8 & -20.7 & -21.5 & -21.7 & -21.3 & -21.0 & -20.6 \\
\hline Current account balance (before grants) $1 /$ & -9.3 & -12.4 & -10.9 & -12.2 & -16.1 & -16.5 & -15.8 & -15.3 & -14.8 & -14.4 \\
\hline General government fiscal balance & -3.0 & 0.0 & 0.7 & -1.5 & -1.0 & -1.8 & -1.5 & -1.2 & -1.4 & -1.4 \\
\hline
\end{tabular}

Sources: Statistics Office, National Bank of Serbia, Ministry of Finance; and Fund staff estimates and projections.

1/ Corrected in 2004-05 for the impact of the VAT introduction.

2/ Including changes in inventories.

3/ Equal to the absoption gap (GDP minus domestic demand). 
Table 4. Serbia: Balance of Payments, 2003-12

(In percent of GDP)

\begin{tabular}{|c|c|c|c|c|c|c|c|c|c|c|c|c|}
\hline & 2003 & 2004 & 2005 & 2006 & $\begin{array}{l}12-m \text { thru } \\
\text { Oct-07 }\end{array}$ & $\begin{array}{c}2007 \\
\text { Jan.-Oct. }\end{array}$ & $\begin{array}{l}2007 \\
\text { Proj. }\end{array}$ & $\begin{array}{l}2008 \\
\text { Proj. }\end{array}$ & $\begin{array}{l}2009 \\
\text { Proj. }\end{array}$ & $\begin{array}{l}2010 \\
\text { Proj. }\end{array}$ & $\begin{array}{l}2011 \\
\text { Proj. }\end{array}$ & $\begin{array}{l}2012 \\
\text { Proj. }\end{array}$ \\
\hline Trade balance & $\begin{array}{ll}-19.8 \\
\end{array}$ & -26.4 & -20.2 & -19.6 & -21.0 & -20.8 & -20.7 & -21.6 & -21.9 & -21.6 & -21.4 & -21.2 \\
\hline Trade balance with effect VAT & -19.8 & -24.3 & -22.1 & -19.6 & -21.0 & -20.8 & -20.7 & -21.6 & -21.9 & -21.6 & -21.4 & -21.2 \\
\hline Exports f.o.b. & 16.3 & 16.6 & 18.9 & 20.4 & 21.7 & 21.7 & 21.4 & 21.3 & 21.1 & 20.8 & 21.0 & 21.5 \\
\hline Imports f.o.b. & -36.1 & -43.0 & -39.1 & -40.0 & -42.7 & -42.5 & -42.1 & -42.9 & -43.0 & -42.5 & -42.4 & -42.6 \\
\hline Intermediate goods (c.i.f.) & -21.1 & -25.1 & -25.3 & -26.1 & -27.1 & -26.9 & $\ldots$ & $\ldots$ & $\ldots$ & $\ldots$ & $\ldots$ & .. \\
\hline Equipment goods (c.i.f.) & -7.1 & -9.1 & -6.3 & -6.5 & -7.6 & -7.7 & $\ldots$ & $\ldots$ & $\ldots$ & $\ldots$ & $\ldots$ & $\ldots$ \\
\hline Consumer goods (c.i.f.) & -9.0 & -10.4 & -8.8 & -8.9 & -9.6 & -9.5 & $\ldots$ & $\ldots$ & $\ldots$ & $\ldots$ & $\ldots$ & $\ldots$ \\
\hline Services (non-factor services, net) & 1.0 & 0.7 & 0.0 & -0.2 & -0.1 & 0.0 & 0.0 & 0.1 & 0.2 & 0.3 & 0.5 & 0.6 \\
\hline Net factor income & -0.7 & -0.9 & -1.2 & -1.2 & -1.5 & -1.6 & -1.6 & -2.1 & -2.3 & -2.6 & -2.7 & -2.8 \\
\hline Private remittances, net $1 /$ & 10.1 & 12.9 & 11.7 & 8.8 & 5.7 & 6.0 & 6.2 & 7.1 & 8.1 & 8.6 & 8.8 & 9.0 \\
\hline Current account balance, before grants & -9.3 & -13.6 & -9.7 & -12.2 & -16.9 & -16.4 & -16.1 & -16.5 & -15.8 & -15.3 & -14.8 & -14.4 \\
\hline C.A. balance b. grants, corrected for VAT effect & -9.3 & -12.4 & -10.9 & -12.2 & -16.9 & -16.4 & -16.1 & -16.5 & -15.8 & -15.3 & -14.8 & -14.4 \\
\hline Official grants & 2.3 & 1.9 & 1.3 & 0.7 & 0.6 & 0.6 & 0.6 & 0.6 & 0.6 & 0.6 & 0.6 & 0.6 \\
\hline Current account balance, after grants & -7.0 & -11.7 & -8.5 & -11.5 & -16.3 & -15.8 & -15.5 & -15.9 & -15.3 & -14.7 & -14.3 & -13.8 \\
\hline Primary current account balance, after grants & -6.3 & -10.8 & -7.2 & -10.3 & -14.8 & -14.2 & -13.9 & -13.8 & -13.0 & -12.1 & -11.6 & -11.1 \\
\hline Capital transfers & 0.0 & 0.0 & 0.0 & 2.7 & 0.0 & -1.2 & -1.0 & 0.0 & 0.0 & 0.0 & 0.0 & 0.0 \\
\hline Foreign direct investment, net & 6.7 & 3.9 & 5.9 & 13.7 & 7.1 & 3.9 & 3.9 & 4.1 & 3.5 & 3.4 & 3.4 & 3.3 \\
\hline Portfolio investment & $\ldots$ & $\ldots$ & $\ldots$ & 1.1 & 2.2 & 2.6 & 2.5 & 1.5 & 1.5 & 1.6 & 1.6 & 1.7 \\
\hline Foreign loans, net ${ }^{2 /}$ & 3.9 & 8.2 & 10.1 & 12.8 & 11.3 & 11.1 & 13.9 & 8.2 & 8.5 & 8.4 & 8.2 & 8.0 \\
\hline Other capital inflows & 0.5 & 0.3 & 1.6 & 3.6 & 4.1 & 3.7 & 3.5 & 2.2 & 1.7 & 1.3 & 1.1 & 0.8 \\
\hline Commercial banks, net ${ }^{3 /}$ & 0.0 & 0.2 & 0.5 & 0.0 & 0.9 & 0.5 & 0.0 & 0.0 & 0.0 & 0.0 & 0.0 & 0.0 \\
\hline Capital account balance & 11.0 & 12.6 & 18.1 & 33.8 & 25.6 & 20.7 & 22.7 & 15.9 & 15.3 & 14.7 & 14.3 & 13.8 \\
\hline Overall balance & 3.2 & 1.8 & 7.8 & 19.1 & 7.5 & 4.1 & 7.2 & 0.0 & 0.0 & 0.0 & 0.0 & 0.0 \\
\hline Financing & -3.2 & -1.8 & -7.8 & -19.1 & -7.5 & -4.1 & -7.2 & 0.0 & 0.0 & 0.0 & 0.0 & 0.0 \\
\hline Net foreign assets of central bank (increase, -) & -3.2 & -1.8 & -7.8 & -19.1 & -7.5 & -4.1 & -7.2 & 0.0 & 0.0 & 0.0 & 0.0 & 0.0 \\
\hline \multicolumn{13}{|l|}{ Memorandum items: } \\
\hline GDP (millions of US\$) & 20,340 & 24,518 & 26,238 & 31,779 & 38,983 & 33,048 & 40,715 & 46,449 & 51,210 & 56,309 & 61,733 & 67,368 \\
\hline Exp & 50.0 & 23.0 & 21.8 & 30.5 & . & $\ldots$ & 34.4 & 13.2 & 9.4 & 8.7 & 10.3 & 11.9 \\
\hline Export volume & 31.7 & 5.3 & 13.2 & 5.7 & $\ldots$ & $\ldots$ & 15.9 & 12.9 & 12.5 & 12.1 & 12.2 & 12.3 \\
\hline Export prices $\mathrm{g}$ & 13.9 & 16.8 & 7.5 & 23.5 & $\ldots$ & $\ldots$ & 16.0 & 0.3 & -2.8 & -3.1 & -1.7 & -0.4 \\
\hline Impor & 34.9 & 43.7 & -2.8 & 23.9 & $\ldots$ & $\ldots$ & 34.9 & 16.0 & 10.6 & 8.7 & 9.4 & 9.8 \\
\hline Impor & 14.4 & 20.8 & -14.1 & 7.8 & $\ldots$ & $\ldots$ & 23.9 & 13.2 & 13.2 & 11.0 & 10.5 & 9.9 \\
\hline Import pric & 18.0 & 19.0 & 13.2 & 15.0 & $\ldots$ & $\ldots$ & 8.8 & 2.5 & -2.3 & -2.1 & -1.0 & -0.1 \\
\hline Change in terms of trade change (percent) & -3.5 & -1.7 & -5.1 & 7.2 & $\ldots$ & $\ldots$ & 6.6 & -2.2 & -0.5 & -1.0 & -0.7 & -0.3 \\
\hline Gros & & & & & & & & & & & & \\
\hline & 3,550 & 4,225 & 5,843 & 11,888 & 13,929 & 13,929 & 14,600 & 14,600 & 14,600 & 14,600 & 14,600 & 14,600 \\
\hline In months of prospective imports of g. \& s. & 3.6 & 4.3 & 4.7 & 7.1 & $\ldots$ & $\ldots$ & 7.5 & 6.8 & 6.3 & 5.7 & 5.2 & 4.8 \\
\hline Gross external debt & 66.7 & 57.5 & 58.9 & 61.7 & 62.6 & 62.6 & 62.0 & 62.6 & 65.3 & 67.8 & 70.0 & 72.2 \\
\hline Gross external private debt & $\ldots$ & 18.1 & 24.1 & 35.1 & 39.8 & 39.8 & 41.4 & 44.1 & 48.1 & 52.0 & 55.4 & 58.6 \\
\hline Net foreign liabilities & 62.3 & 55.5 & 58.9 & 63.8 & $\cdots$ & $\cdots$ & 65.8 & 73.7 & 82.1 & 89.4 & 95.8 & 101.5 \\
\hline Debt service, cash & 2.0 & 2.7 & 3.7 & 6.2 & 9.6 & 9.2 & 8.5 & 10.6 & 14.2 & 17.9 & 21.4 & 24.0 \\
\hline Principal & 0.9 & 1.5 & 2.1 & 4.4 & 7.4 & 7.0 & 6.3 & 7.9 & 11.4 & 14.7 & 18.1 & 20.6 \\
\hline Interest & 1.0 & 1.2 & 1.6 & 1.9 & 2.1 & 2.2 & 2.2 & 2.7 & 2.9 & 3.2 & 3.3 & 3.4 \\
\hline
\end{tabular}

1/ Projections based on most recent observations.

2/ Excluding IMF loans.

3/ Commercial banks and gross foreign reserves excluding intervalutary changes 
Table 5. Serbia: Indicators of External Vulnerability, 2003-07 1/

(In percent of GDP, unless otherwise indicated)

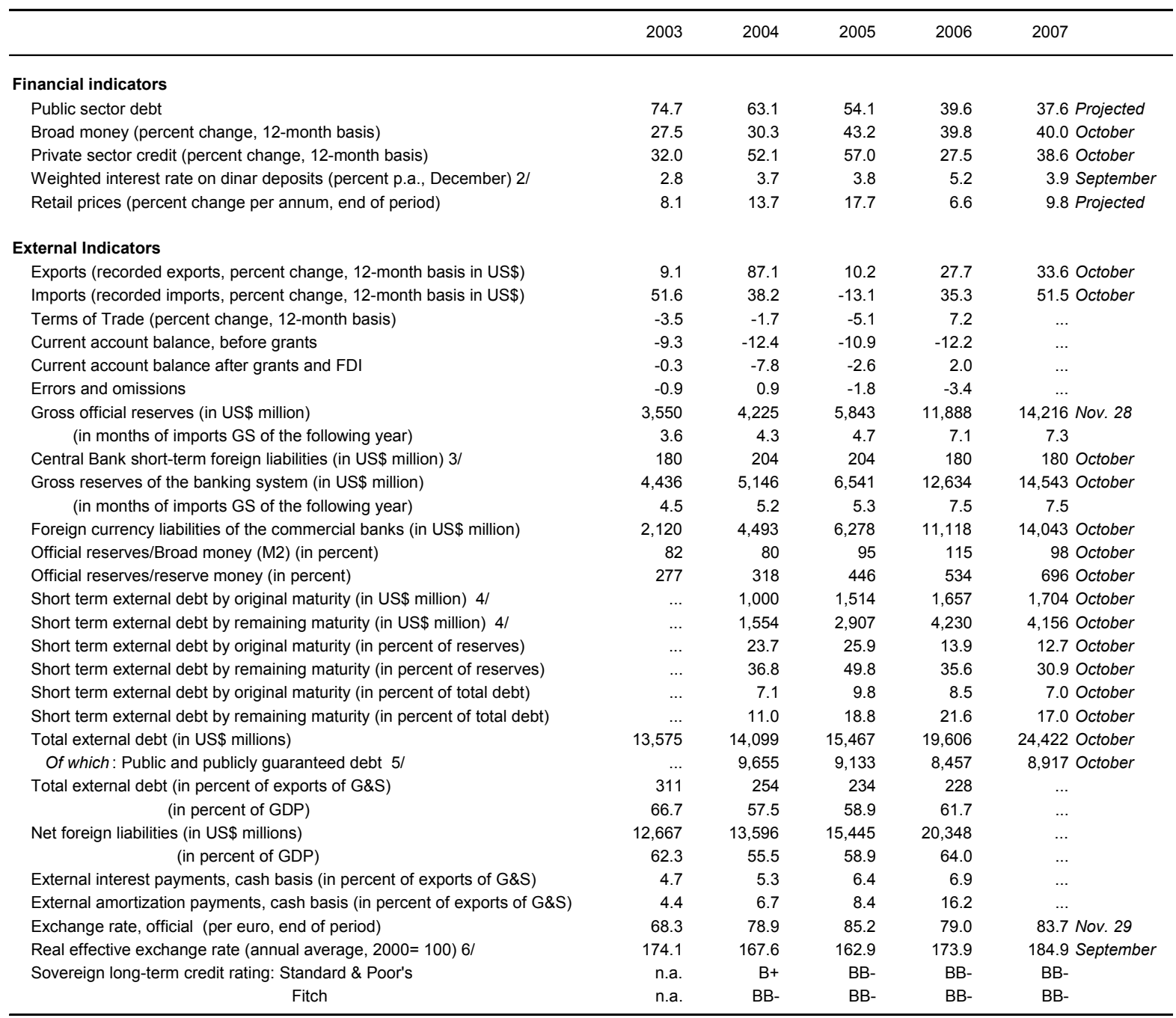

Sources: Serbian authorities; and Fund staff estimates.

1/ All stocks are measured end-of-period. Excludes Kosovo, except for external debt.

2/ Weighted average of interest rates on commercial paper, bank bills, and certificates of deposit.

3/ Excluding IMF and liabilities to domestic residents. In 2002, the NBS assumed short-tem external debt of commercial banks of \$100 million.

$4 /$ Includes overdue obligations on debt related to imports of oil and gas. Short-term external debt by remaining maturity also includes amortization due in the following year on medium- and long-term debt.

5/ Assuming all long- and medium-term external debt of banks and enterprises is government guaranteed.

$6 /$ Increase denotes appreciation. 
Table 6. Serbia: External Debt, October 31, 2007

(In millions of US\$)

\begin{tabular}{|c|c|c|c|c|c|}
\hline Sector / Creditor & $\begin{array}{l}\text { Outstanding } \\
\text { Debt } \\
\text { (principal) }\end{array}$ & $\begin{array}{c}\text { Principal } \\
\text { Arrears }\end{array}$ & $\begin{array}{l}\text { Interest } \\
\text { Arrears }\end{array}$ & $\begin{array}{l}\text { Late } \\
\text { Interest }\end{array}$ & Total \\
\hline Total Debt & 23,411 & 1,720 & 475 & 536 & 24,422 \\
\hline Public sector borrowing & 8,494 & 407 & 212 & 212 & 8,917 \\
\hline Medium and long-term debt & 8,419 & 407 & 212 & 212 & 8,842 \\
\hline Monetary Authority - National Bank of Serbia & 100 & 100 & 20 & 37 & 157 \\
\hline Governments & 7,824 & 307 & 192 & 175 & 8,191 \\
\hline Multilateral institutions & 4,003 & - & - & - & 4,003 \\
\hline \multicolumn{6}{|l|}{ Of which: } \\
\hline IBRD - consolidated debt & 2,315 & - & - & - & 2,315 \\
\hline IDA & 614 & - & - & - & 614 \\
\hline European Community & 395 & - & - & - & 395 \\
\hline Governments - Total Paris Club & 2,266 & - & - & - & 2,266 \\
\hline Other Governments & 312 & 246 & 162 & 162 & 636 \\
\hline London Club & 1,108 & 30 & 29 & 13 & 1,151 \\
\hline Other Creditors - Credit concluded after Dec. 2000 & 105 & - & - & - & 105 \\
\hline Debt in non-convertible currency & 31 & 31 & - & - & 31 \\
\hline Governments guaranteed & 495 & - & - & - & 495 \\
\hline Short-term Debt & 75 & - & - & - & 75 \\
\hline Private sector borrowing & 14,917 & 1,313 & 263 & 325 & 15,504 \\
\hline Medium and long-term debt & 13,290 & 833 & 261 & 325 & 13,875 \\
\hline Banks & 3,813 & 66 & 83 & 60 & 3,956 \\
\hline International financial organizations & 500 & 12 & 6 & 9 & 515 \\
\hline Governments - Permanent Paris Club members & 158 & - & - & - & 158 \\
\hline Other Creditors & 3,155 & 54 & 77 & 51 & 3,283 \\
\hline Enterprises & 9,477 & 768 & 178 & 264 & 9,920 \\
\hline International financial organizations & 261 & 7 & 2 & - & 263 \\
\hline Governments - Permanent Paris Club members & 45 & 0 & 0 & - & 46 \\
\hline Other Governments & 22 & 22 & 6 & 4 & 31 \\
\hline Other Creditors & 9,088 & 676 & 156 & 261 & 9,505 \\
\hline Debt in non-convertible currency & 62 & 62 & 13 & - & 75 \\
\hline Short-term Debt & 1,627 & 479 & 2 & - & 1,629 \\
\hline Banks & 1,454 & 399 & - & - & 1,454 \\
\hline Enterprises & 172 & 81 & 2 & - & 175 \\
\hline
\end{tabular}

Source: National Bank of Serbia 
Table 7. Serbia: General Government Fiscal Operations, 2003-08 1/

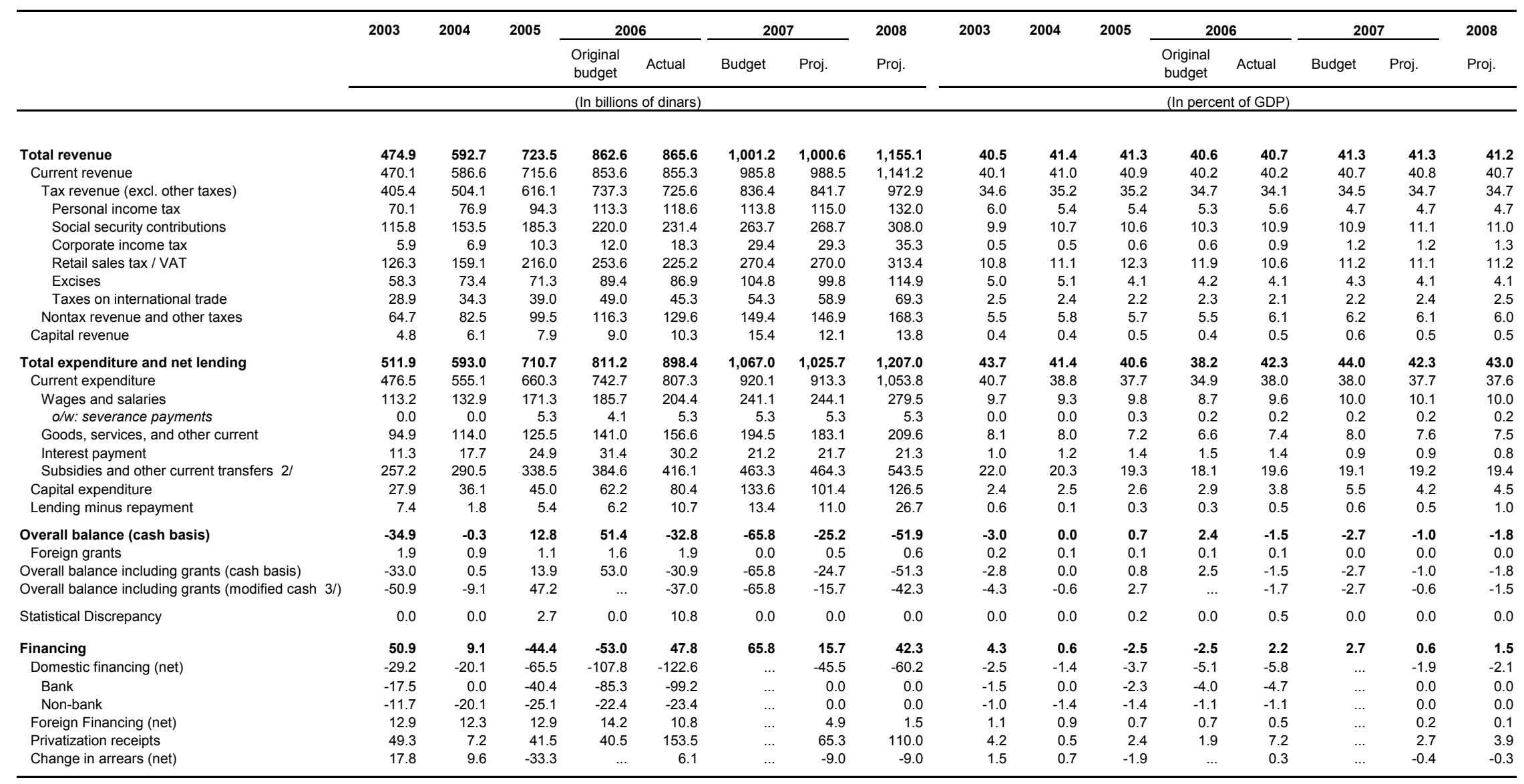

Sources: Ministry of Finance; and Fund staff estimates and projections.

1/ Includes the union, republican, and local governments, social security funds, and the Road fund.

2/ Excluding foreign currency deposit payments to households, reclassified below the line.

3/ Cash balance minus change in arrears. 
Table 8. Serbia: Government and Government-Guaranteed Debt, 2000-06

(End-period stock by creditor, in percent of GDP)

\begin{tabular}{|c|c|c|c|c|c|c|c|}
\hline & 2000 & 2001 & 2002 & 2003 & 2004 & 2005 & 2006 \\
\hline Gross debt (excluding IMF) & 233.5 & 111.3 & 77.4 & 74.7 & 63.1 & 54.2 & 39.3 \\
\hline Domestic & 77.9 & 38.4 & 31.8 & 32.0 & 29.5 & 22.0 & 16.2 \\
\hline Foreign currency-denominated & 60.1 & 29.2 & 23.2 & 22.8 & 20.5 & 17.0 & 12.1 \\
\hline Frozen Foreign Currency Deposits & 60.1 & 29.2 & 23.2 & 22.8 & 20.3 & 16.8 & 12.0 \\
\hline Other & 0.0 & 0.0 & 0.0 & 0.0 & 0.2 & 0.2 & 0.1 \\
\hline Local currency-denominated & 17.8 & 9.1 & 8.6 & 9.2 & 9.0 & 5.0 & 4.1 \\
\hline T-bills & 0.0 & 0.0 & 0.0 & 0.2 & 0.4 & 0.3 & 0.2 \\
\hline Long-term loans & 0.5 & 0.3 & 1.8 & 1.8 & 1.4 & 1.1 & 0.8 \\
\hline Credit from the banking system & 3.9 & 2.1 & 2.4 & 2.0 & 2.1 & 1.3 & 1.0 \\
\hline Domestic arrears & 13.4 & 6.8 & 4.3 & 5.3 & 5.0 & 2.2 & 2.1 \\
\hline External & 155.6 & 72.9 & 45.7 & 42.7 & 33.5 & 32.1 & 22.3 \\
\hline Multilateral (excluding IMF) & 30.9 & 15.5 & 13.9 & 14.3 & 14.7 & 13.8 & 10.5 \\
\hline IBRD & 26.8 & 13.8 & 10.9 & 10.6 & 10.0 & 8.8 & 6.0 \\
\hline IDA & 0.0 & 0.0 & 1.0 & 1.3 & 1.7 & 1.9 & 1.5 \\
\hline EIB & 0.0 & 0.0 & 0.6 & 0.8 & 1.0 & 1.2 & 1.3 \\
\hline EBRD & 0.0 & 0.0 & 0.0 & 0.2 & 0.5 & 0.6 & 0.6 \\
\hline $\mathrm{EU}+\mathrm{CEB}$ & 4.1 & 1.7 & 1.3 & 1.5 & 1.4 & 1.3 & 1.1 \\
\hline Official Bilateral & 80.3 & 37.5 & 17.6 & 15.8 & 14.5 & 13.9 & 8.9 \\
\hline Paris Club & 72.9 & 32.6 & 13.9 & 12.5 & 11.4 & 10.6 & 6.5 \\
\hline Other bilateral & 0.2 & 0.1 & 0.3 & 0.4 & 0.5 & 0.5 & 0.4 \\
\hline Debt under negotiation $1 /$ & 7.2 & 4.8 & 3.4 & 2.9 & 2.6 & 2.8 & 2.0 \\
\hline Commercial & 44.4 & 19.9 & 14.1 & 12.6 & 4.4 & 4.4 & 3.0 \\
\hline London Club & 44.4 & 19.9 & 14.1 & 12.6 & 4.4 & 4.4 & 3.0 \\
\hline Local government debt & $\ldots$ & $\ldots$ & $\ldots$ & $\ldots$ & $\ldots$ & $\ldots$ & 0.7 \\
\hline \multicolumn{8}{|l|}{ Memorandum items: } \\
\hline Debt to IMF & 2.4 & 2.3 & 3.3 & 4.3 & 3.9 & 3.6 & 0.7 \\
\hline Government deposits & 2.4 & 1.9 & 3.6 & 4.0 & 3.6 & 4.9 & 7.4 \\
\hline Net debt (excl. IMF) & 231.1 & 109.4 & 73.8 & 70.7 & 59.4 & 49.3 & 31.2 \\
\hline Kosovo debt & 17.2 & 9.0 & 5.8 & 5.6 & 4.7 & 4.2 & 3.0 \\
\hline \multicolumn{8}{|l|}{ Share in total gross debt of: } \\
\hline Foreign currency-denominated debt & 92.4 & 91.8 & 88.9 & 87.7 & 85.7 & 90.8 & 89.5 \\
\hline Short-term debt & 0.0 & 0.0 & 0.0 & 0.2 & 0.7 & 0.5 & 0.6 \\
\hline Debt at variable interest rates & 33.0 & 30.8 & 19.7 & 18.8 & 20.3 & 22.0 & 19.7 \\
\hline Debt to official creditors & 47.6 & 47.7 & 40.7 & 40.4 & 46.2 & 51.2 & 50.1 \\
\hline
\end{tabular}

Source: Ministry of Finance; and Fund staff estimates.

1/ Bilateral credits concluded before 2000; non-regulated London Club debt; debt in non-convertible currencies. 
Table 9. Serbia: Monetary Survey, 2003-07

(In billions of RSD; end of period) $1 /$

\begin{tabular}{|c|c|c|c|c|c|}
\hline & 2003 & 2004 & 2005 & 2006 & $\begin{array}{c}2007 \\
\text { October }\end{array}$ \\
\hline Net Foreign Assets 2/ & 172.7 & 196.6 & 320.2 & 653.3 & 684.9 \\
\hline (NFA in euro billion) & 2.5 & 2.5 & 3.7 & 8.3 & 8.9 \\
\hline Assets & 242.3 & 298.2 & 472.4 & 757.9 & 777.9 \\
\hline NBS & 194.0 & 245.9 & 422.0 & 713.0 & 745.0 \\
\hline Commercial banks & 48.4 & 52.2 & 50.4 & 44.9 & 32.8 \\
\hline Liabilities (-) & -69.7 & -101.6 & -152.2 & -104.6 & -93.0 \\
\hline NBS & -59.7 & -67.9 & -77.8 & -25.6 & -9.6 \\
\hline Commercial banks & -10.0 & -33.7 & -74.4 & -78.9 & -83.4 \\
\hline Net Domestic Assets & 64.3 & 112.1 & 121.8 & -34.9 & 75.3 \\
\hline Domestic credit & 153.4 & 248.1 & 360.9 & 398.7 & 519.2 \\
\hline Net credit to government & -23.6 & -21.8 & -62.1 & -136.2 & -186.4 \\
\hline Credit & 23.2 & 30.4 & 23.1 & 22.1 & 21.3 \\
\hline Dinar credit & 23.1 & 30.3 & 22.2 & 21.4 & 20.6 \\
\hline NBS & 19.1 & 21.4 & 15.2 & 14.9 & 14.2 \\
\hline Commercial banks & 4.1 & 8.8 & 7.0 & 6.5 & 6.4 \\
\hline Foreign currency credits & 0.1 & 0.1 & 0.9 & 0.7 & 0.7 \\
\hline NBS & 0.0 & 0.0 & 0.2 & 0.0 & 0.0 \\
\hline Commercial banks & 0.1 & 0.1 & 0.7 & 0.7 & 0.7 \\
\hline Liabilities & -46.8 & -52.2 & -85.3 & -158.3 & -207.7 \\
\hline Dinar liabilities & -25.7 & -38.8 & -60.9 & -50.4 & -112.9 \\
\hline NBS & -14.3 & -28.1 & -46.6 & -29.1 & -80.8 \\
\hline Commercial banks & -11.4 & -10.7 & -14.2 & -21.3 & -32.1 \\
\hline Foreign currency deposits & -21.2 & -13.4 & -24.4 & -107.9 & -94.8 \\
\hline NBS & -18.1 & -10.0 & -18.8 & -103.4 & -90.6 \\
\hline Commercial banks & -3.1 & -3.4 & -5.6 & -4.5 & -4.2 \\
\hline Short-term government credits to banks & -0.2 & -0.4 & -0.5 & -0.3 & -0.3 \\
\hline Purchased FFCD bonds & 4.9 & 8.2 & 12.1 & 10.7 & 2.8 \\
\hline Credit to the non-government sector & 172.3 & 262.0 & 411.5 & 524.5 & 703.1 \\
\hline Households & 28.6 & 64.4 & 124.9 & 196.1 & 279.4 \\
\hline Non-profit and other sectors & 1.4 & 2.4 & 4.2 & 4.8 & 5.0 \\
\hline Enterprises in dinar & 91.4 & 138.4 & 224.3 & 278.4 & 379.4 \\
\hline Enterprises in foreign currency & 50.9 & 56.8 & 58.1 & 45.1 & 39.3 \\
\hline Enterprises in fx (euro billion) & 0.7 & 0.7 & 0.7 & 0.6 & 0.5 \\
\hline Other items, net & -89.1 & -136.0 & -239.1 & -433.6 & -444.0 \\
\hline Broad Money (M2) & 236.9 & 308.7 & 442.0 & 618.4 & 760.1 \\
\hline Dinar-denominated M2 & 117.0 & 132.2 & 175.4 & 262.0 & 296.3 \\
\hline M1 & 98.2 & 106.1 & 138.9 & 190.6 & 194.3 \\
\hline Currency outside banks & 43.0 & 45.2 & 53.7 & 68.5 & 61.6 \\
\hline Demand deposits & 55.2 & 60.9 & 85.3 & 122.1 & 132.7 \\
\hline Time and savings deposits & 18.8 & 26.1 & 36.4 & 71.4 & 102.1 \\
\hline Fx-deposits (non-frozen) & 119.9 & 176.5 & 266.6 & 356.4 & 463.8 \\
\hline Fx-deposits (non-frozen; euro billion) & 1.8 & 2.2 & 3.1 & 4.5 & 6.0 \\
\hline \multicolumn{6}{|l|}{ Memorandum items: } \\
\hline \multicolumn{6}{|l|}{ 12-month growth rates (in percent) } \\
\hline Broad Money (M2) & 27.5 & 30.3 & 43.2 & 39.8 & 40.0 \\
\hline Dinar-denominated M2 & $\ldots$ & 13.0 & 32.6 & 49.4 & 42.9 \\
\hline M1 & $\ldots$ & 8.0 & 30.9 & 37.1 & 32.0 \\
\hline Currency outside banks & $\ldots$ & 5.1 & 18.8 & 27.6 & 23.5 \\
\hline Fx-deposits & $\ldots$ & 47.2 & 51.1 & 33.6 & 38.1 \\
\hline Credit to non-government & $\ldots$ & 52.1 & 57.0 & 27.5 & 38.6 \\
\hline Credit to households & $\ldots$ & 125.0 & 93.9 & 57.0 & 52.6 \\
\hline Credit to enterprises & $\ldots$ & 37.2 & 44.6 & 14.6 & 30.9 \\
\hline Velocity (M1) & 11.6 & 14.5 & 13.6 & 11.4 & 12.1 \\
\hline Credit euroization $3 /$ & 52.8 & 67.8 & 76.8 & 79.6 & 73.0 \\
\hline Deposit euroization 4/ & 61.7 & 66.9 & 68.6 & 65.5 & 66.4 \\
\hline Multiplier (Dinar M2/Reserve money) & 1.7 & 1.7 & 1.9 & 2.0 & 2.8 \\
\hline Currency/Dinar deposits (in percent) & 58.0 & 51.9 & 44.1 & 35.4 & 26.2 \\
\hline Required reserve ratio (effective, in percent) & 21.1 & 24.1 & 21.4 & 17.7 & 13.9 \\
\hline Excess reserves/Dinar deposits (in percent) & 10.8 & 9.1 & 10.7 & 16.3 & 7.6 \\
\hline Fx-deposits/Broad money & 50.6 & 57.2 & 60.3 & 57.6 & 61.0 \\
\hline SRD-denominated M2/ annualized monthly GDP & 10.3 & 8.6 & 9.3 & 12.0 & 12.6 \\
\hline
\end{tabular}

Sources: National Bank of Serbia; and Fund staff estimates and calculations.

1/ Foreign exchange denominated items are converted at current exchange rates.

2/ Excluding undivided assets and liabilities of the SFRY and, from 2002 onwards, liabilities to banks in liquidation.

$3 /$ Share of fx-indexed and fx-denominated bank credit in total bank credit to non-government.

4/ Share of foreign currency deposits in total non-government deposits at commercial banks.

\section{(C) International Monetary Fund. Not for Redistribution}


Table 10. Serbia: Banking Sector Financial Soundness Indicators, 2002-07

(End-of-period quarterly, in percent)

\begin{tabular}{|c|c|c|c|c|c|c|}
\hline & 2002 & 2003 & 2004 & 2005 & 2006 & $\begin{array}{l}2007 \\
\text { June }\end{array}$ \\
\hline \multicolumn{7}{|l|}{ Capital Adequacy } \\
\hline Capital to risk-weighted assets & 25.6 & 31.1 & 27.9 & 26.0 & 24.7 & 25.9 \\
\hline Tier 1 capital to risk-weighted assets & 18.1 & 29.8 & 25.6 & 22.2 & 24.2 & 24.8 \\
\hline Total regulatory capital to total assets & 18.3 & 22.5 & 18.8 & 16.0 & 15.6 & 15.9 \\
\hline \multicolumn{7}{|l|}{ Asset Quality } \\
\hline Nonperforming loans to total loans $1 /$ & $\ldots$ & $\ldots$ & $\ldots$ & $\ldots$ & 11.7 & 10.4 \\
\hline Nonperforming loans net of provisions to total loans $1 /$ & $\ldots$ & $\ldots$ & $\ldots$ & $\ldots$ & 4.11 & 3.45 \\
\hline Share of risky loans to total loans $2 /$ & $\ldots$ & $\ldots$ & 22.2 & 23.8 & 23.1 & 21.4 \\
\hline FX denominated and FX indexed loans to total loans & 49.7 & 63.3 & 69.9 & 88.1 & 83.5 & 75.8 \\
\hline \multicolumn{7}{|l|}{ Earnings and Profitability } \\
\hline Net income to average assets (ROA) & -8.4 & -0.3 & -1.2 & 1.1 & 1.7 & 2.1 \\
\hline Net income to average capital (ROE) & -60.6 & -1.2 & -5.3 & 6.7 & 10.0 & 12.8 \\
\hline Net interest income to average total assets & 5.6 & 6.0 & 6.4 & 6.3 & 6.6 & 7.2 \\
\hline Noninterest expense to gross income & 188.9 & 110.5 & 132.9 & 117.6 & 104.9 & 97.9 \\
\hline Personnel expense to gross income & $\ldots$ & 10.5 & 9.3 & 9.0 & 6.5 & 6.6 \\
\hline Interest income to gross income & 45.6 & 24.3 & 22.6 & 24.1 & 19.4 & 23.8 \\
\hline Noninterest income to gross income & 54.4 & 75.7 & 77.4 & 75.9 & 80.6 & 76.2 \\
\hline Personnel expenses to noninterest expenses & $\ldots$ & 9.5 & 7.0 & 7.6 & 6.2 & 6.7 \\
\hline Customer deposits to total loans & 118.4 & 115.0 & 97.5 & 99.4 & 109.2 & 105.0 \\
\hline \multicolumn{7}{|l|}{ Liquidity } \\
\hline Liquid assets to total assets & 25.7 & 20.0 & 21.0 & 28.8 & 41.4 & 39.6 \\
\hline
\end{tabular}

Source: National Bank of Serbia.

1/ Based on 9 largest banks in Serbia - loans past due more than 90 days.

2/ Assets (net of provisions) classified by the NBS as receivables in C, D, and E risk categories with provisioning requirements of 25 percent, 50 percent, and 100 percent, respectively. 
Table 11. Serbia: Medium-Term Scenarios, 2003-12

(In percent of GDP, unless otherwise indicated)

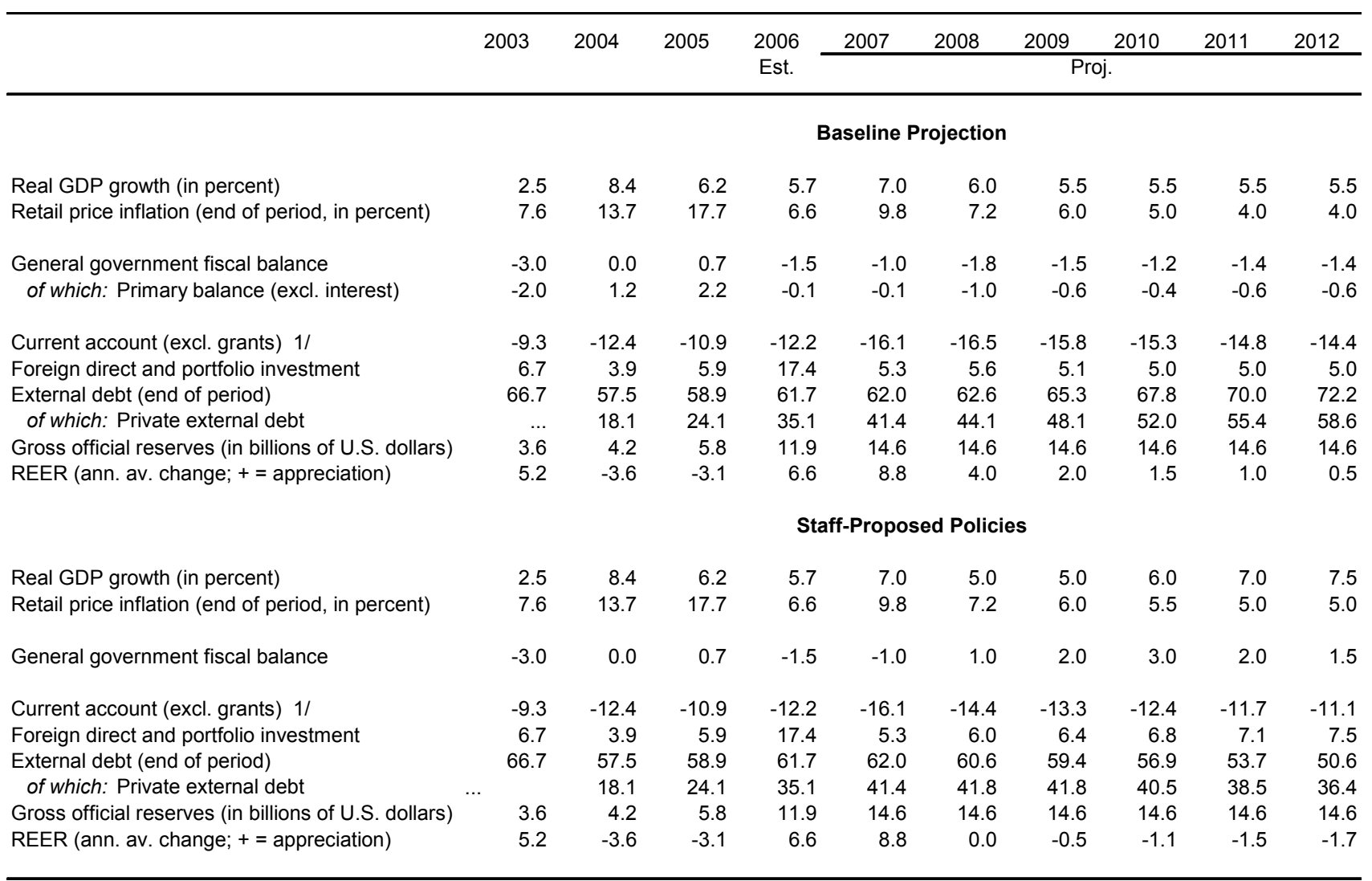

Sources: Serbian authorities; and IMF staff estimates and projections.

1/ Corrected for the impact of the VAT introduction in 2005. 
Table 12. Serbia: Employment by Ownership, 2001-07

\begin{tabular}{|c|c|c|c|c|c|c|c|c|c|}
\hline & $\begin{array}{l}2001 \\
\text { Sept. }\end{array}$ & $\begin{array}{l}2002 \\
\text { Sept. }\end{array}$ & $\begin{array}{l}2003 \\
\text { Sept. }\end{array}$ & $\begin{array}{l}2004 \\
\text { Sept. }\end{array}$ & $\begin{array}{l}2005 \\
\text { Sept. }\end{array}$ & $\begin{array}{l}2006 \\
\text { Sept. }\end{array}$ & $\begin{array}{c}2007 \\
\text { March }\end{array}$ & $\begin{array}{c}\text { Change } \\
07 / 06\end{array}$ & $\begin{array}{c}\text { Change } \\
07 / 01\end{array}$ \\
\hline & \multicolumn{9}{|c|}{ (In thousand) } \\
\hline Total employment & 2,788 & 2,736 & 2,710 & 2,679 & 2,654 & 2,521 & 2,506 & -15 & -282 \\
\hline General government & 322 & 321 & 324 & 327 & 325 & 313 & 317 & 4 & -4 \\
\hline State-owned enterprises & 187 & 184 & 183 & 181 & 174 & 162 & 159 & -4 & -29 \\
\hline Socially owned enterprises & 644 & 580 & 417 & 324 & 258 & 235 & 208 & -27 & -435 \\
\hline Mixed ownership & 377 & 334 & 392 & 399 & 358 & 301 & 285 & -17 & -92 \\
\hline Private sector & 1,258 & 1,317 & 1,395 & 1,447 & 1,540 & 1,510 & 1,537 & 27 & 279 \\
\hline of which: Non-farm private & 566 & 630 & 721 & 805 & 953 & 1,008 & 1,035 & 27 & 469 \\
\hline Companies & 209 & 228 & 280 & 328 & 421 & 436 & 469 & 33 & 261 \\
\hline Entrepreneurs and their employees & 358 & 401 & 441 & 477 & 531 & 572 & 566 & -6 & 208 \\
\hline & \multicolumn{9}{|c|}{ (In percent of total) } \\
\hline Total employment & 100 & 100 & 100 & 100 & 100 & 100 & 100 & 0 & 0 \\
\hline General government & 12 & 12 & 12 & 12 & 12 & 12 & 13 & 0 & 1 \\
\hline State-owned enterprises & 7 & 7 & 7 & 7 & 7 & 6 & 6 & 0 & 0 \\
\hline National & 5 & 5 & 5 & 5 & 4 & 4 & 4 & 0 & -1 \\
\hline Local & 2 & 2 & 2 & 2 & 2 & 2 & 2 & 0 & 0 \\
\hline Socially owned enterprises & 23 & 21 & 15 & 12 & 10 & 9 & 8 & -1 & -15 \\
\hline Mixed ownership & 14 & 12 & 14 & 15 & 13 & 12 & 11 & -1 & -2 \\
\hline Private sector & 45 & 48 & 51 & 54 & 58 & 60 & 61 & 1 & 16 \\
\hline of which: Non-farm private & 20 & 23 & 27 & 30 & 36 & 40 & 41 & 1 & 21 \\
\hline
\end{tabular}

Source: Statistics Office. 
Table 13. Serbia: Profit and Losses of Enterprises, 2004-06 (In percent of GDP)

\begin{tabular}{|c|c|c|c|c|c|c|c|c|c|}
\hline & \multicolumn{3}{|c|}{ Profit-making enterprises } & \multicolumn{3}{|c|}{ Loss-making enterprises } & \multicolumn{3}{|c|}{ Net Results } \\
\hline & 2004 & 2005 & 2006 & 2004 & 2005 & 2006 & 2004 & 2005 & 2006 \\
\hline Non-financial corporates & 7.8 & 10.2 & 13.4 & -11.9 & -12.1 & -8.3 & -4.2 & -1.9 & 5.1 \\
\hline Private and mixed & 6.6 & 8.3 & 12.6 & -6.3 & -7.5 & -5.9 & 0.3 & 0.8 & 6.7 \\
\hline State and socially owned & 1.1 & 1.8 & 0.7 & -5.5 & -4.4 & -1.6 & -4.5 & -2.6 & -0.9 \\
\hline Other $1 /$ & 0.1 & 0.0 & 0.1 & -0.1 & -0.2 & -0.9 & 0.0 & -0.1 & -0.8 \\
\hline Banks (active) & 0.6 & 0.6 & 1.0 & -1.0 & -0.3 & -0.3 & -0.4 & 0.3 & 0.8 \\
\hline Other entities $2 /$ & 0.6 & 0.7 & 0.6 & -0.2 & -0.1 & -0.2 & 0.4 & 0.6 & 0.4 \\
\hline Total & 8.9 & 11.5 & 15.0 & -13.0 & -12.5 & -8.8 & -4.1 & -1.0 & 6.3 \\
\hline
\end{tabular}

Source: NBS Solvency Center.

$1 /$ Including companies in bankruptcy in 2006.

2/ Entrepreneurs, nonbank financial sector, other. 


\section{Appendix I. Serbia: External Debt Sustainability}

\section{Reflecting unbalanced economic policies, Serbia's external debt has been rising} since 2004 despite rescheduling operations and early repayments to some multilateral creditors, including the Fund (Table A1). ${ }^{13}$ It reached \$24 billion in October 2007, a 30 percent annual increase. The rise was led by private debt, which doubled since mid-2006. In particular, nonbank private debt has been rising sharply in recent months ( 95 percent $y / y$

Serbia: External Stock of Debt, October 2007

\begin{tabular}{lrrr}
\hline & $\begin{array}{c}\text { Stock } \\
\text { (billions } \\
\text { of US\$) }\end{array}$ & $\begin{array}{c}\text { y/y } \\
\text { (percent) }\end{array}$ & $\begin{array}{c}\text { Percent of } \\
\text { 12-m cum. } \\
\text { monthly } \\
\text { GDP }\end{array}$ \\
\hline Total external debt & 24.4 & 29.7 & 62.6 \\
Official & 8.9 & 2.4 & 22.9 \\
Private & 15.5 & 53.1 & 39.8 \\
Medium/long term & 22.7 & 31.3 & 58.3 \\
$\quad$ Official & 8.8 & 2.7 & 22.7 \\
$\quad$ Private & 13.9 & 59.8 & 35.6 \\
$\quad$ Banks & 4.0 & 9.7 & 10.1 \\
$\quad$ Other private & 9.9 & 95.3 & 25.4 \\
Short term & 1.7 & 10.7 & 4.4 \\
\hline
\end{tabular}

Source: National Bank of Serbia and staff estimates. in dollar terms), as prudential regulation on bank activity became tighter. As a result, debt is now mostly private, a sharp reversal from less than two years ago. ${ }^{14}$

\begin{tabular}{lrrr}
\multicolumn{3}{l}{ Serbia: Structure of External Debt, 2005-07 } \\
\hline & End-05 & End-06 & Oct. 07 \\
\hline & \multicolumn{4}{c}{ (Percent of total debt) } \\
Public & 59 & 43 & 37 \\
Private & 41 & 57 & 63 \\
$\quad$ Banks & 17 & 26 & 22 \\
Other private & 24 & 31 & 41 \\
Total & 100 & 100 & 100
\end{tabular}

Source: NBS and staff estimates.

2. The associated vulnerabilities are considerable.

- $\quad$ The debt remains vulnerable to a depreciation of the exchange rate, which could be triggered for instance by political uncertainties or a disorderly resolution of the issue of Kosovo's status.

- $\quad$ The impact of the depreciation shock would be compounded by large unhedged forex indebtedness in the domestic banking system - the consequence of widespread financial euroization. Household and corporate indebtedness could rise sharply, with negative consequences for financial (notably banking) sector soundness.

\footnotetext{
${ }^{13}$ See the related discussion in the 2006 Article IV report (IMF Country Report No. 06/384, Appendix III).

${ }^{14}$ Notwithstanding this sharp rise in nominal debt, the external debt ratio has remained around 60 percent of GDP over the past few years, partly on account of domestic currency appreciation.
} 
- In the medium-term, external debt and financing requirements are projected to continue to rise significantly if economic policies are not rebalanced so as to reduce the current account deficit. In addition, the sustainability of FDI is not assured, unless "greenfield" investment takes over from "non-renewable" FDI (sale of assets). This, in turn, would require a significant improvement in the business environment in Serbia. Moreover, the pool of assets that can be sold (state-owned companies, licenses) not only is finite, but the ability to sell public assets could also be threatened by a degradation in the political climate.

\section{Standard and ad-hoc DSA tests illustrate these risks:}

- Standard bound tests show the sensitivity of the debt path to the current account position and the exchange rate. (Figure A1). A larger deterioration of the current account would rapidly contribute to further build up of external debt, and a 30 percent nominal depreciation of the dinar would push the debt-to-GDP ratio above 90 percent of GDP. In contrast, a scenario assuming key variables at their historical averages shows a return to a sustainable path of external debt. This is because the deterioration of Serbia's external position is only recent, The tests also show low sensitivity to interest rate and growth rate shocks.

- $\quad$ Ad-hoc scenarios show a rapid increase in external debt (exceeding 100 percent of GDP in the worst case) should FDI be lower than in the baseline scenario (Figure A2). These tests include: (i) a standard bound test with FDI lower by half of the historical standard deviation; (ii) stalled privatization; (iii) significantly lower greenfield investment; and (iv) a combination of (iii) and (iv). In these scenarios, only the direct effect of lesser non-debt creating flows was estimated, not the second round effect on productivity and growth, which would worsen the debt profile. 
Figure A1. Serbia: External Debt Sustainability: Bound Tests 1/ (External debt in percent of GDP)
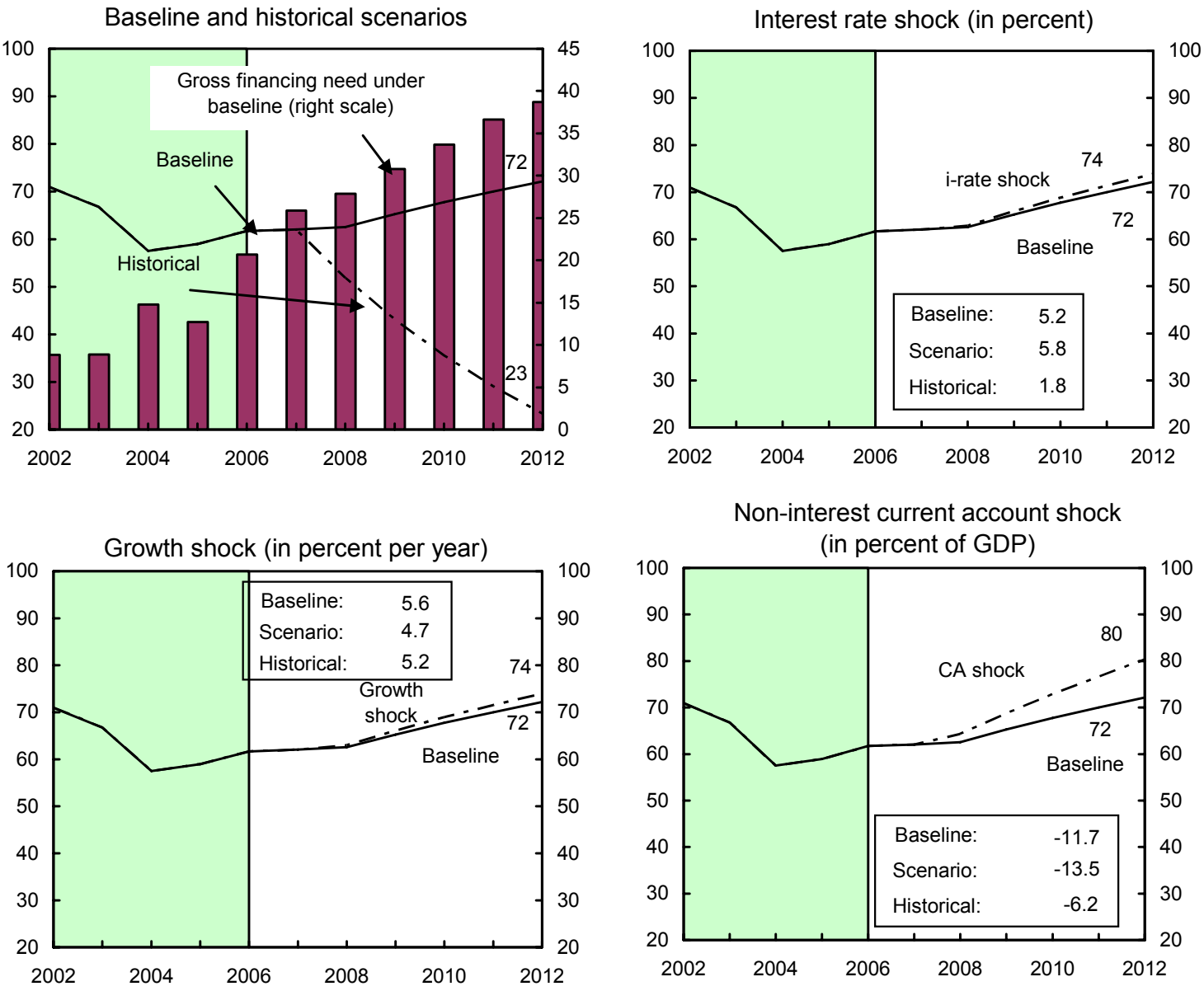

Combined shock 2/

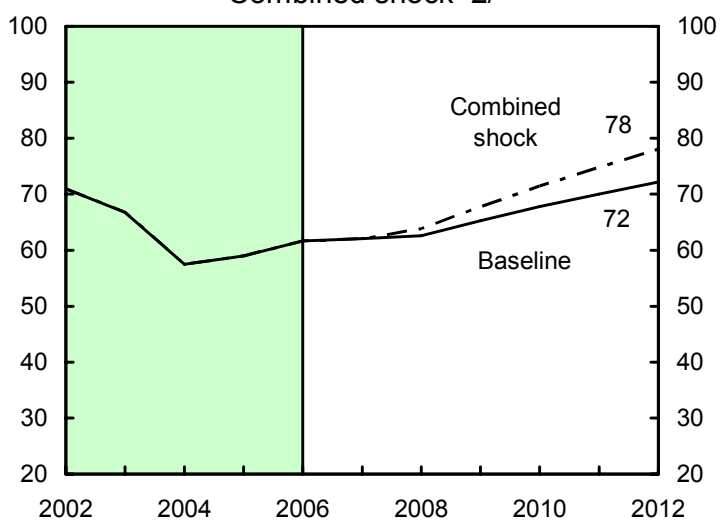

Real depreciation shock $3 /$

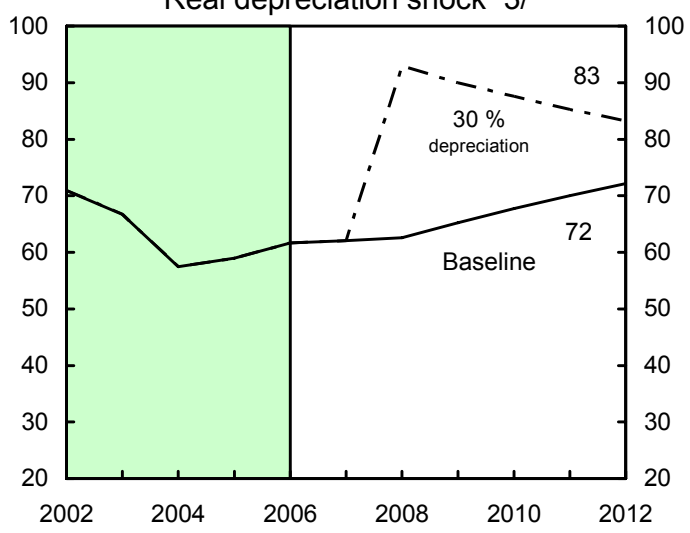

Sources: International Monetary Fund, Country desk data, and staff estimates.

1/ Shaded areas represent actual data. Individual shocks are permanent one-half standard deviation shocks. Figures in the boxes represent average projections for the respective variables in the baseline and scenario being presented. Seven-year historical average for the variable is also shown.

2/ Permanent 1/2 standard deviation shocks applied to real interest rate, growth rate, and current account balance.

3/ One-time real depreciation of 30 percent occurs in 2008. 
Figure A2. Serbia: External Debt Sustainability: Illustrative Tests 1/ (External debt in percent of GDP)

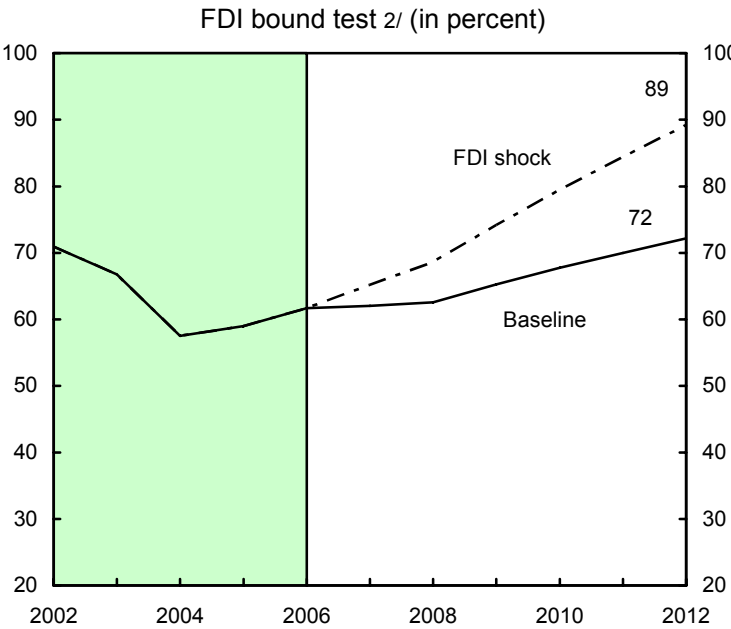

Lower greenfield investment (20 percent of baseline)

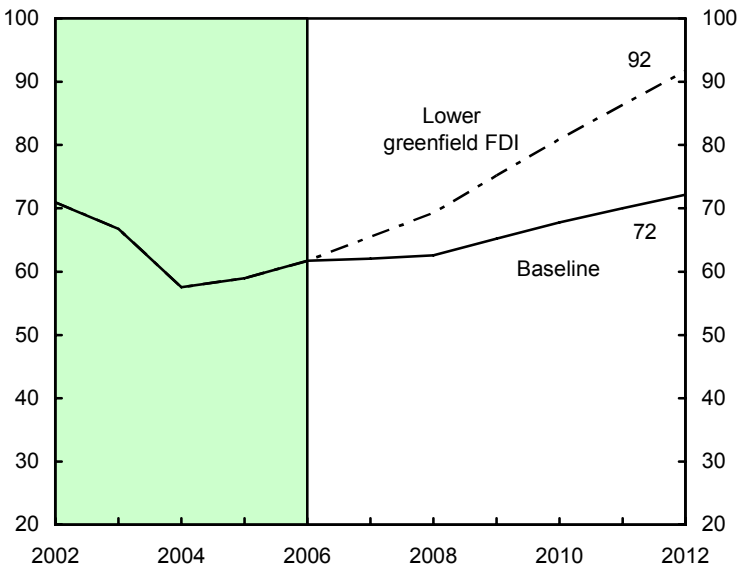

No privatization receipt

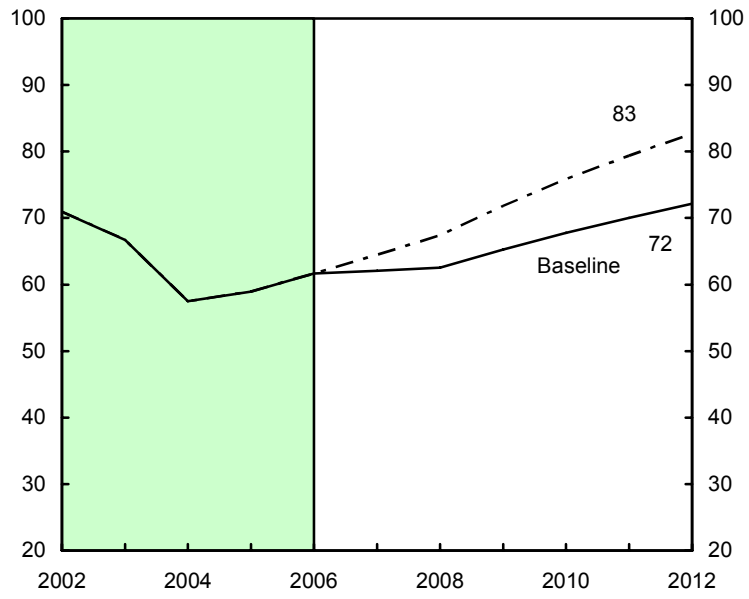

No privatization and lower greenfield investment

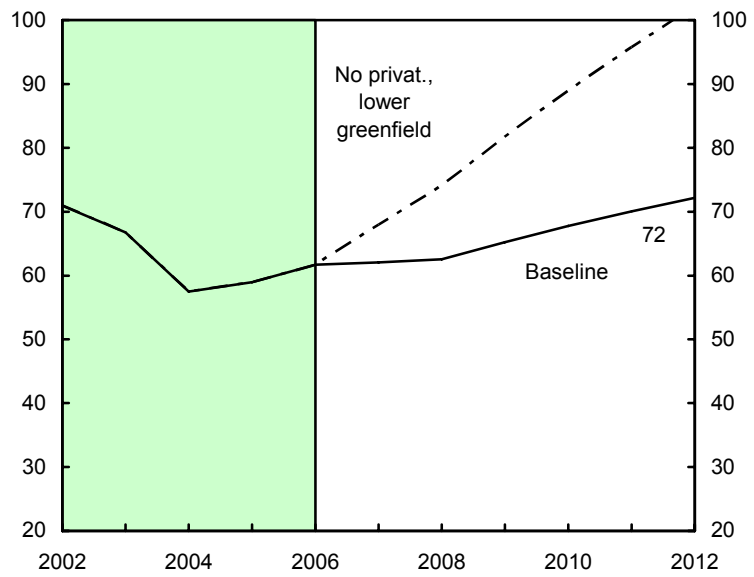

Sources: International Monetary Fund, Country desk data, and staff estimates.

$1 /$ Shaded areas represent actual data. Illustrative tests are not scenarios per se as they do not take into account macro linkages, but only shocks on specific variables.

2/ Permanent 1/2 standard deviation shock. 
Table A1. Serbia: External Debt Sustainability Framework, 2002-12 (In percent of GDP, unless otherwise indicated)

\begin{tabular}{|c|c|c|c|c|c|c|c|c|c|c|c|c|}
\hline & \multicolumn{5}{|c|}{ Actual } & \multicolumn{7}{|c|}{ Projections } \\
\hline & 2002 & 2003 & 2004 & 2005 & 2006 & 2007 & 2008 & 2009 & 2010 & 2011 & 2012 & Debt-stabilizing \\
\hline & & & & & & & & & & & & current account 6 / \\
\hline Baseline: External debt & 70.9 & 66.7 & 57.5 & 59.0 & 61.7 & 62.0 & 62.6 & 65.3 & 67.8 & 70.0 & 72.2 & -8.3 \\
\hline Change in external debt & -23.7 & -4.2 & -9.2 & 1.5 & 2.7 & 0.4 & 0.5 & 2.7 & 2.5 & 2.2 & 2.1 & \\
\hline Identified external debt-creating flows $(4+8+9)$ & -24.5 & -15.9 & -3.9 & -2.8 & -19.8 & 3.3 & 4.9 & 5.4 & 5.2 & 4.8 & 4.5 & \\
\hline Current account deficit, excluding interest payments & 7.0 & 6.0 & 10.5 & 6.9 & 9.7 & 13.3 & 13.2 & 12.4 & 11.5 & 11.0 & 10.4 & \\
\hline Deficit in balance of goods and services & -57.0 & -61.6 & -71.0 & -70.6 & -73.9 & -77.9 & -78.6 & -78.6 & -77.9 & -77.9 & -78.8 & \\
\hline Exports & 18.7 & 21.4 & 22.7 & 25.2 & 27.0 & 28.6 & 28.5 & 28.4 & 28.3 & 28.5 & 29.1 & \\
\hline Imports & -38.3 & -40.2 & -48.3 & -45.4 & -46.8 & -49.3 & -50.0 & -50.1 & -49.6 & -49.5 & -49.7 & \\
\hline Net non-debt creating capital inflows (negative) & -8.1 & -7.2 & -4.2 & -7.5 & -21.0 & -8.8 & -7.8 & -6.8 & -6.3 & -6.1 & -5.8 & \\
\hline Automatic debt dynamics $1 /$ & -23.5 & -14.7 & -10.2 & -2.1 & -8.4 & -1.2 & -0.5 & -0.3 & 0.0 & -0.1 & -0.2 & \\
\hline Contribution from nominal interest rate & 0.9 & 1.0 & 1.2 & 1.6 & 1.9 & 2.2 & 2.7 & 2.9 & 3.2 & 3.3 & 3.4 & \\
\hline Contribution from real GDP growth & -3.0 & -1.4 & -4.7 & -3.3 & -2.8 & -3.4 & -3.3 & -3.1 & -3.3 & -3.4 & -3.5 & \\
\hline Contribution from price and exchange rate changes $2 /$ & -21.4 & -14.3 & -6.7 & -0.4 & -7.5 & $\ldots$ & $\ldots$ & $\ldots$ & $\ldots$ & $\ldots$ & $\ldots$ & \\
\hline Residual, incl. change in gross foreign assets $(2-3) 3$ / & 0.8 & 11.7 & -5.3 & 4.3 & 22.5 & -2.9 & -4.4 & -2.7 & -2.6 & -2.6 & -2.4 & \\
\hline External debt-to-exports ratio (in percent) & 379.2 & 311.5 & 253.6 & 234.1 & 228.1 & 216.8 & 219.2 & 229.4 & 239.6 & 245.7 & 247.9 & \\
\hline Gross external financing need (in billions of US dollars) 4 / & 1.4 & 1.8 & 3.6 & 3.3 & 6.6 & 10.5 & 13.0 & 15.8 & 19.0 & 22.6 & 26.1 & \\
\hline in percent of GDP & 8.8 & 8.9 & 14.8 & 12.7 & 20.7 & 25.9 & 27.9 & 30.8 & 33.7 & 36.6 & 38.7 & \\
\hline Scenario with key variables at their historical averages 5/ & & & & & & 62.0 & 51.9 & 43.2 & 35.6 & 29.0 & 23.3 & -11.1 \\
\hline \multicolumn{13}{|l|}{ Key Macroeconomic Assumptions Underlying Baseline } \\
\hline Real GDP growth (in percent) & 4.2 & 2.5 & 8.4 & 6.2 & 5.7 & 7.0 & 6.0 & 5.5 & 5.5 & 5.5 & 5.5 & \\
\hline GDP deflator in US dollars (change in percent) & 29.2 & 25.3 & 11.2 & 0.7 & 14.6 & 19.7 & 7.6 & 4.5 & 4.2 & 3.9 & 3.4 & \\
\hline Nominal external interest rate (in percent) & 1.2 & 1.8 & 2.2 & 3.0 & 3.8 & 4.5 & 5.0 & 5.1 & 5.4 & 5.3 & 5.3 & \\
\hline Growth of exports (US dollar terms, in percent) & 21.6 & 47.2 & 27.6 & 18.8 & 30.1 & 35.6 & 13.8 & 9.9 & 9.3 & 10.4 & 11.5 & \\
\hline Growth of imports (US dollar terms, in percent) & 34.7 & 35.0 & 45.0 & 0.4 & 25.1 & 34.9 & 15.7 & 10.5 & 8.8 & 9.3 & 9.6 & \\
\hline Current account balance, excluding interest payments & -7.0 & -6.0 & -10.5 & -6.9 & -9.7 & -13.3 & -13.2 & -12.4 & -11.5 & -11.0 & -10.4 & \\
\hline Net non-debt creating capital inflows & 8.1 & 7.2 & 4.2 & 7.5 & 21.0 & 8.8 & 7.8 & 6.8 & 6.3 & 6.1 & 5.8 & \\
\hline
\end{tabular}

1/ Derived as $[r-g-\rho(1+g)+\varepsilon \alpha(1+r)] /(1+g+\rho+g \rho)$ times previous period debt stock, with $r=$ nominal effective interest rate on external debt; $\rho=$ change in domestic GDP deflator in US dollar terms, $g=$ real GDP growth rate, $\mathrm{e}=$ nominal appreciation (increase in dollar value of domestic currency), and $a=$ share of domestic-currency denominated debt in total external debt.

$2 /$ The contribution from price and exchange rate changes is defined as $[-\rho(1+g)+\varepsilon \alpha(1+r)] /(1+g+\rho+g \rho)$ times previous period debt stock. $\rho$ increases with an appreciating domestic currency $(\varepsilon>0)$ and rising inflation (based on GDP deflator).

3/ For projection, line includes the impact of price and exchange rate changes.

4/ Defined as current account deficit, plus amortization on medium- and long-term debt, plus short-term debt at end of previous period

5/ The key variables include real GDP growth; nominal interest rate; dollar deflator growth; and both non-interest current account and non-debt inflows in percent of GDP.

6/ Long-run, constant balance that stabilizes the debt ratio assuming that key variables (real GDP growth, nominal interest rate, dollar deflator growth, and non-debt inflows in percent of GDP) remain at their levels of the last projection year.

\section{CInternational Monetary Fund. Not for Redistribution}




\section{Appendix II. Serbia: Public Debt Sustainability}

General government debt in Serbia is sustainable under current fiscal policies and robust GDP growth. However, its sensitivity to shocks-exchange rate shocks in particularhighlights potential vulnerabilities. Sustainability is less assured if quasi-fiscal losses of state-owned and socially owned enterprises are taken into account, or if the plan to provide restitution for assets confiscated after World War II proves too costly.

1. Under the baseline scenario, Serbia's gross debt-to-GDP ratio would decline from 40 percent of GDP in 2006 and stabilize at 27 percent of GDP in 2012 (Table A1). ${ }^{15}$ The sharp reduction in debt in 2006 reflects significant Paris Club debt relief (about $\$ 600$ million). The baseline assumes stabilization of the fiscal deficit at around $1 \frac{1}{2}$ percent of GDP in the medium term. Thus, the decline in the debt-to-GDP ratio is due to projected real GDP growth and the favorable terms on the current debt stock (most of public external debt is on concessional terms). Real interest rates are assumed to increase over time, however, as borrowing is contracted at market rates. The scenario assumes no privatization receipts: this highlights the underlying debt path in the absence of these one-off receipts or if privatization proceeds are spent.

2. In the stress test using historical averages, the debt path would be somewhat higher than in the baseline, ${ }^{16}$ while in the no-policy-change scenario (assuming a constant primary balance), the debt-to-GDP ratio would decline slightly more than in the baseline. All other tests result in less benign developments (Figure A1). A one-time real depreciation of 30 percent results in a significant increase in the debt ratio, demonstrating the sensitivity of debt dynamics to the exchange rate, as about 90 percent of public debt is foreign currencydenominated (comprising mainly frozen currency deposits and debt to multilaterals and Paris Club creditors).

3. To evaluate the implications of quasi-fiscal losses incurred by state-owned and socially owned enterprises - reported by the Solvency Center at significant levels - a modified scenario takes into account these enterprises' deficit, estimated for illustrative purposes at 2 percent of GDP annually. Under this scenario, the debt-to-GDP ratio would

\footnotetext{
${ }^{15}$ The debt stock includes gross general government and government-guaranteed debt of the Republic of Serbia, including debt to non-Paris Club official creditors under negotiation and in non-convertible currencies.

${ }^{16}$ Stress tests were conducted using the standardized methodology but with modifications due to data constraints. Historical data for Serbia are incomplete prior to 2000 and those available thereafter are affected by debt restructuring operations. Hence, five-year averages (2002-06) were used to replace historical averages for all variables but the interest rate. The real interest rate was assumed at zero for the stress tests and the 1997-2001 data for 4 countries in the region (Albania, Bulgaria, Croatia, and Romania) were used to derive its standard deviation.
} 
increase (to 40 percent of GDP), and the debt path would be much more sensitive to shocks. The scenario also serves to illustrate that significant fiscal loosening would endanger sustainability and increase the risk of public debt distress. This may materialize if spending under the national investment program escalates or large public sector wage hikes become entrenched.

4. The government's plan to provide restitution for confiscated assets after World War II could potentially harm fiscal sustainability. The currently contemplated ceiling of $€ 4$ billion (over 10 percent of GDP), in the absence of compensating expenditure measures, will significantly deteriorate the fiscal position (public debt would increase to 42 percent of GDP in 2012). Moreover, foreign exchange exposure of the government would increase if the financial compensation through the issuance of bonds is be denominated in foreign currency. 
Figure A1. Serbia: Government Debt Sustainability: Bound Tests, 2004-12 1/ (In percent of GDP)

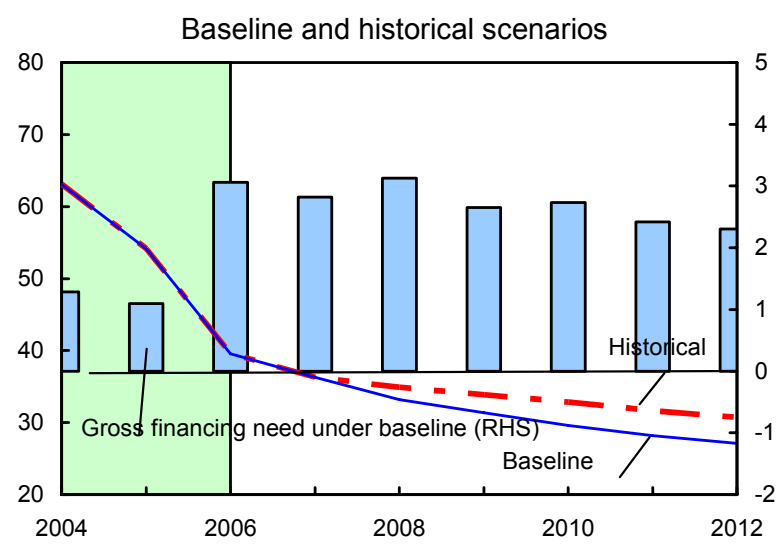

Growth shock (in percent per year)

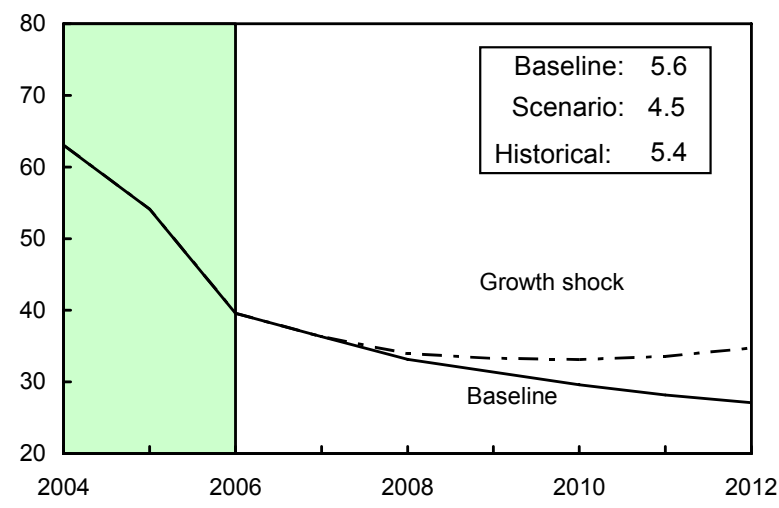

Combined shock 2/

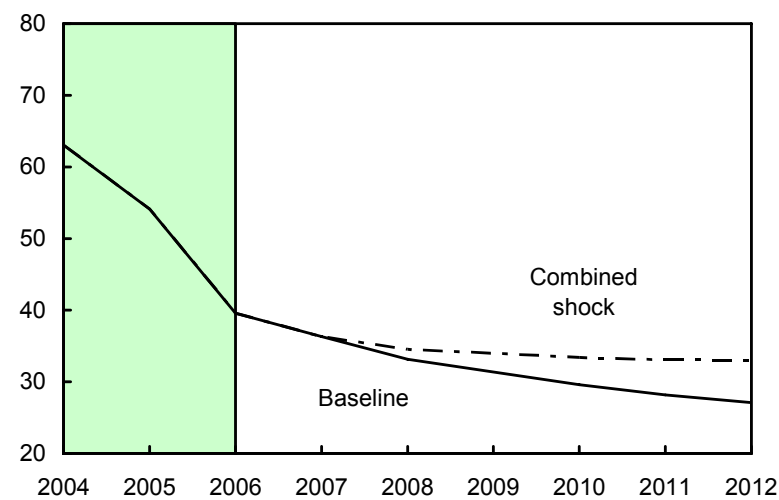

Interest rate shock (in percent)

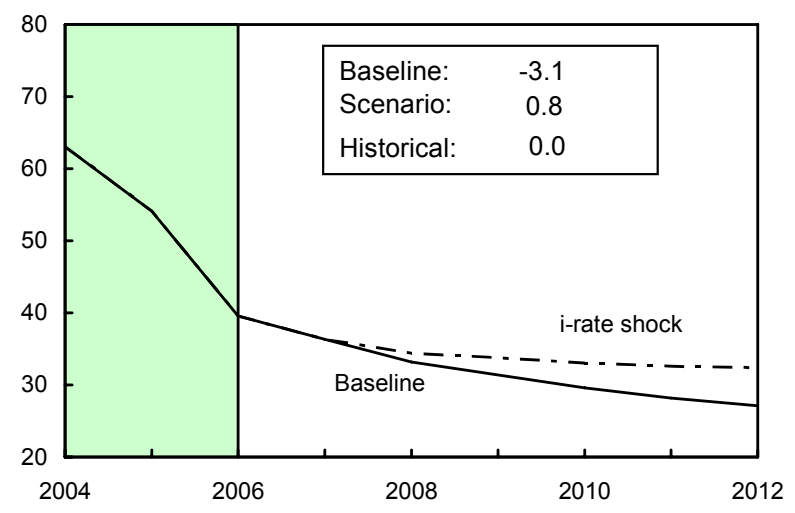

Primary balance shock (in percent of GDP) and no policy change scenario (constant primary balance)
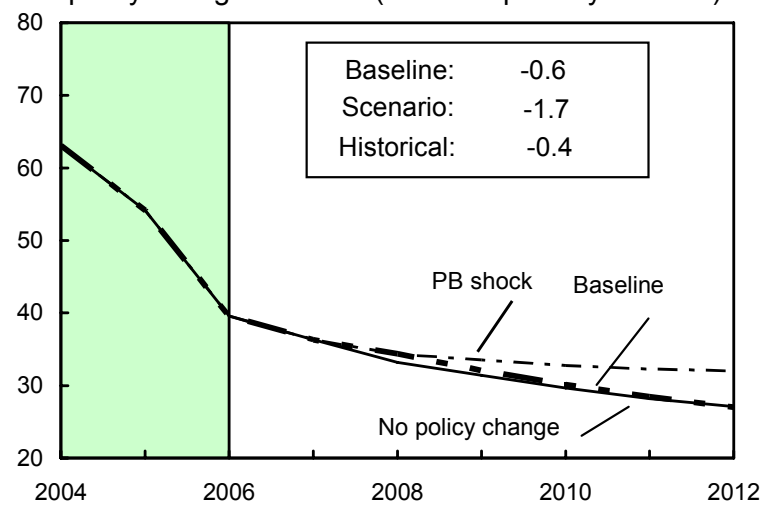

Real depreciation and contingent liabilities shocks $3 /$

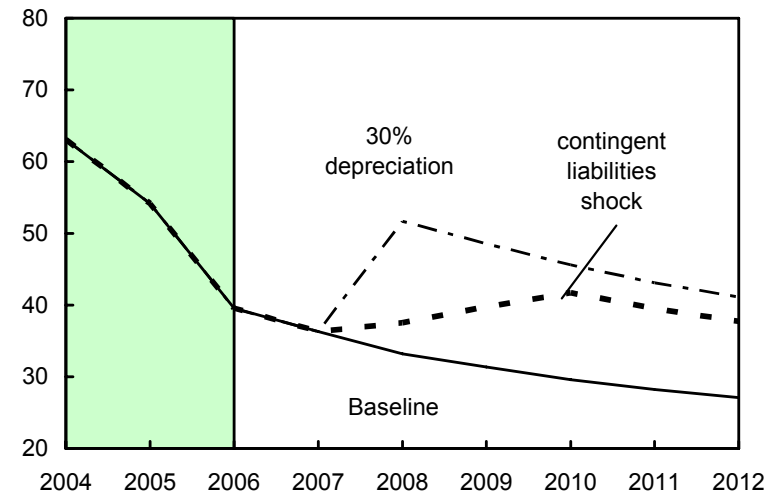

Sources: Serbian authorities; and staff estimates and projections.

1/ Shaded areas represent actual data. Individual shocks are permanent one-half standard deviation shocks. Figures in the boxes represent average projections for the respective variables in the baseline and scenario being presented. Four-year historical average for the variable is also shown.

2/ Permanent $1 / 4$ standard deviation shocks applied to real interest rate, growth rate, and primary balance.

$3 /$ One-time real depreciation of 30 percent, with real depreciation defined as nominal depreciation (measured by percentage fall in dollar value of local currency) minus domestic inflation (based on GDP deflator). Contingent liabilities shock equal to $4 \mathrm{bn}$ euros phased in during 2008-10. 
Table A1. Serbia: Government Debt Sustainability Framework, 2004-12

(In percent of GDP, unless otherwise indicated)

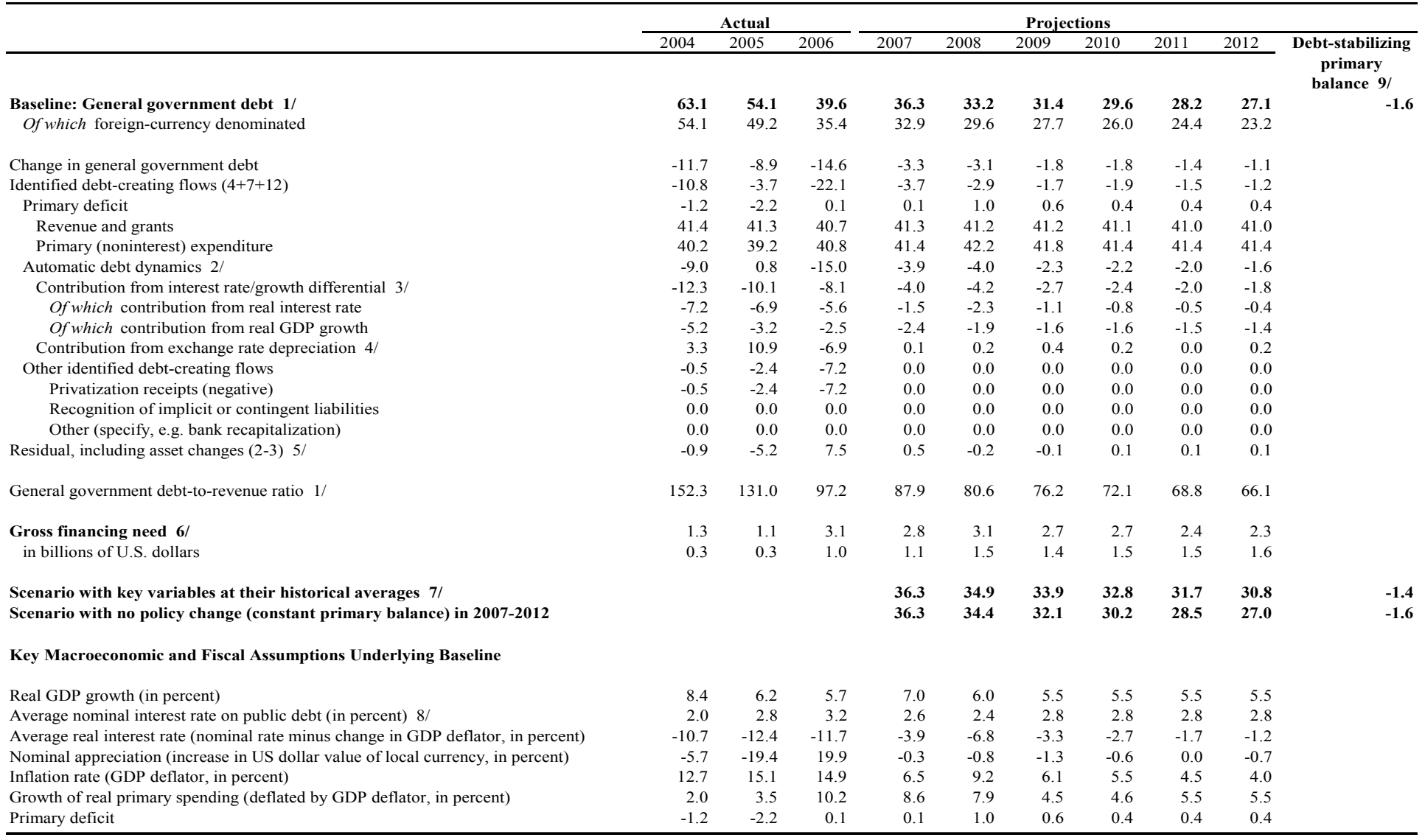

1/ General government and government-guaranteed gross debt.

2/ Derived as $[(\mathrm{r}-\pi(1+\mathrm{g})-\mathrm{g}+\alpha \varepsilon(1+\mathrm{r})] /(1+\mathrm{g}+\pi+\mathrm{g} \pi))$ times previous period debt ratio, with $\mathrm{r}=$ interest rate; $\pi=$ growth rate of GDP deflator; $\mathrm{g}=$ real GDP growth rate; $\alpha=$ share of foreign-currency

denominated debt; and $\varepsilon=$ nominal exchange rate depreciation (measured by increase in local currency value of U.S. dollar).

3/ The real interest rate contribution is derived from the denominator in footnote $2 /$ as $r-\pi(1+\mathrm{g})$ and the real growth contribution as $-\mathrm{g}$.

4 / The exchange rate contribution is derived from the numerator in footnote $2 /$ as $\alpha \varepsilon(1+\mathrm{r})$

5/ For projections, this line includes exchange rate changes.

6/ Defined as general government deficit, plus amortization of medium and long-term government debt, plus short-term debt at end of previous period.

7/ The key variables include real GDP growth; real interest rate; and primary balance in percent of GDP.

8/ Derived as nominal interest expenditure divided by previous period debt stock.

9/ Assumes that key variables (real GDP growth, real interest rate, and other identified debt-creating flows) remain at the level of the last projection year.

CInternational Monetary Fund. Not for Redistribution 
INTERNATIONAL MONETARY FUND

REPUBLIC OF SERBIA

Staff Report for the 2007 Article IV Consultation-Informational Annex

Prepared by the European Department

December 28, 2007

- Mission. Discussions took place in Belgrade during October 25-November 6, 2007. The staff team comprised Messrs. Hilbers (head), Mottu, Mirzoev (all EUR), Dauphin (PDR), Goswami (MCM), and Skaarup (FAD), assisted by Mr. Hirschhofer (Resident Representative) and Ms. Nestorović and Mitrović from the resident office. Mr. Hayward (MCM technical assistance expert) overlapped with the mission. Mr. Antić (OED) attended the policy meetings.

- Country authorities. The mission met with Deputy Prime Minister Djelić, Minister of Finance Cvetković, Minister of Economy and Regional Development Dinkić, Minister of Trade Bubalo, Minister of Energy Popović, Minister in charge of the National Investment Plan Djilas, National Bank of Serbia Governor Jelasić, other key government and NBS officials, and representatives of the private sector, banks, economic research institutes, academia, the EC, and IFIs.

- Fund relations. Serbia is on a standard 12-month consultation cycle. Following early repurchases, Serbia exited post-program monitoring in March 2007 (Appendix I).

- World Bank. The mission coordinated closely with World Bank staff (Appendix II).

- Statistics. Serbia's economic data are broadly adequate for surveillance purposes (Appendix III).

- Outreach. The concluding statement and press conference received broad media coverage. The resident representative carries out an active outreach program. 


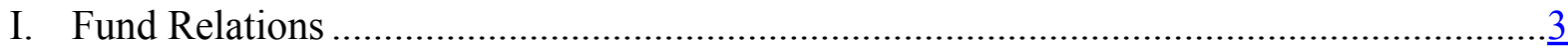

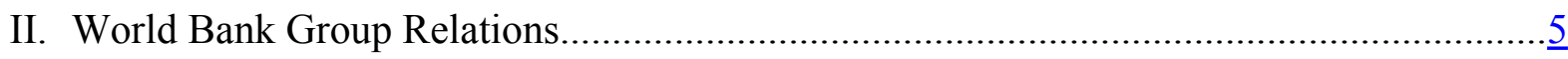

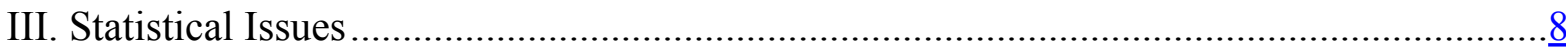




\section{Annex I. Serbia: Fund Relations}

(As of November 30, 2007)

I. Membership Status: Joined December 14, 1992 (succeeding to membership of the former SFR Yugoslavia); accepted Article VIII on May 15, 2002. Serbia continues the membership in the Fund of the former state union of Serbia and Montenegropreviously the Federal Republic of Yugoslavia—since July 2006.

II. General Resources Account:

SDR Million

Quota

467.70

\%Quota

Fund Holdings of Currency

467.71

100.00

Reserve Position

0.00

100.00

III. SDR Department:

SDR Million

56.66

0.00

Net cumulative allocation

0.51

\%Allocation

100.00

Holdings

0.90

IV. Outstanding Purchases and Loans: None.

V. Latest Financial Arrangements:

Type

Approval

Expiration

Amount Approved

$\underline{\text { Amount Drawn }}$

Date

Date

(SDR Million)

$\underline{\text { (SDR Million) }}$

EFF

May 14, 2002

Feb. 28, 2006

650.00

650.00

Stand-By

June 11, 2001 May 31, 2002

200.00

200.00

VI. Projected Obligations to Fund (In millions of SDR):

Principal

\begin{tabular}{lcccc} 
Forthcoming \\
\hline$\underline{2007}$ & $\underline{2008}$ & $\underline{2009}$ & $\underline{2010}$ & $\underline{2011}$
\end{tabular}

Charges/Interest

2.00

1.99

1.99

Total

$\underline{2.00}$

$\underline{1.99}$

VII. Implementation of HIPC Initiative: Not Applicable.

VIII. Implementation of Multilateral Debt Relief Initiative (MDRI): Not Applicable.

IX. Exchange Arrangement: Serbia accepted the obligations under Article VIII, Sections 2, 3, and 4, on May 15, 2002, and maintains a system free of restrictions on payments and transfers for current international transactions, except with respect to blocked pre-1991 foreign currency savings deposits (IMF Country Report No. 02/105). The exchange rate arrangement (de jure and de facto) is a managed floating system since January 1, 2001. 
X. Last Article IV Consultation: Concluded on October 18, 2006 (IMF Country Report No. 06/384).

\section{Analytical Work Undertaken in Past Consultations:}

2005 Consultation:

- Reform agenda for the fiscal sector

- Pension system: issues and reform options

- Deficits of state- and socially owned enterprises

- Inflation determinants

- Euroization: macroeconomic, prudential, and policy implications

- Export performance and external competitiveness

2006 Consultation:

- Capital Formation and External Deficits

- Employment

- Banking System

- Economic Structure and the Choice of Exchange Rate Regime

- Foreign Exchange and Monetary Operations

- Exchange rate pass-through

- Inflation targeting in emerging markets

XI. FSAP Participation: Serbia participated in the Financial Sector Assessment Program in 2005, and the Executive Board discussed the Financial System Stability Assessment in February 2006 (IMF Country Report No. 06/96).

XII. Technical Assistance in the Past 12 Months:

\begin{tabular}{|c|c|c|}
\hline Department & Timing & Purpose \\
\hline MCM & Since May 2006 & Resident advisor for monetary \\
\hline $\mathrm{MCM}$ & $\begin{array}{l}\text { Dec. } 2006 \\
\text { March } 2007 \\
\text { Sept. } 2007\end{array}$ & Modeling and forecasting \\
\hline MCM & $\begin{array}{l}\text { Dec. } 2006 \\
\text { Dec. } 2007\end{array}$ & Liquidity management \\
\hline STA & March 2007 & National Accounts Statistics \\
\hline MCM & $\begin{array}{l}\text { May } 2007 \\
\text { Nov. } 2007\end{array}$ & Foreign Exchange Operations \\
\hline
\end{tabular}

XIII. Resident Representative:

Mr. Harald Hirschhofer took up his position as Resident Representative in September 2004. 


\section{Annex II. Serbia: World Bank Group Relations}

\section{Partnership with Serbia's Development Strategy}

1. Following the formation of the coalition government in mid-2007, the World Bank has been discussing the policy reform agenda with the Government. Support for the Governments' development strategy from the World Bank and the IMF follow the agreed upon division of responsibilities between the two institutions.

2. The Fund takes the lead on macroeconomic policies (fiscal, monetary, and exchange rate) aimed at facilitating sustainable growth, while the Bank takes the lead on structural policy. In areas of direct interest to the Fund, the Bank leads the policy dialogue in: (i) public expenditure management; (ii) macroeconomically important sectoral reforms (e.g., in the energy sector); (iii) pension, health, and social assistance reform; (iv) restructuring and privatization of enterprises; and (v) legal reforms with a bearing on the business environment, including labor markets. The Bank and the Fund have jointly led the policy dialogue in the financial sector, including on the restructuring and privatization of banks, and in foreign trade.

\section{The World Bank}

3. As of December 2007, total IDA credits and grants committed to Serbia by the Bank since 2001 amount to approximately $\$ 740$ million, with an additional $\$ 145$ million in IBRD commitments. The Bank has assisted Serbia to make progress against key objectives set out in the Country Assistance Strategy (CAS) for FY05-07: (i) streamlining the public sector (the overall fiscal adjustment has been limited with early gains being reversed, but there has been a trend toward higher capital expenditure); (ii) encouraging private sector growth (annual growth averaging 6 percent, with Serbia the lead reformer in Doing Business 2006); and (iii) reducing poverty (which fell from 12.7 percent in 2002 to 8.8 percent in 2006). Serbia has now graduated from IDA status and will borrow on IBRD terms in the future.

4. At end-2007, Serbia has a portfolio of 10 Bank-supported projects under implementation with a total commitment value of \$398 million (including IDA, IBRD and GEF). Investment support focuses on (i) transport and energy infrastructure aimed at encouraging regional integration and spurring economic growth; (ii) agricultural, environment, and irrigation investments to improve production and help Serbia meet EU standards; (iii) pension and health sector reform to strengthen the quality of service and improve financial sustainability; (iv) strengthened land administration; (v) energy efficiency; and (vi) regional development in the economically depressed former mining region of Bor.

5. A new Country Partnership Strategy (CPS) was discussed by the World Bank Board of Executive Directors on December 13, 2007. The CPS envisages base case IBRD lending of $\$ 600$ million over the period FY08-11. The CPS' three main pillars are to (i) encourage 
dynamic private sector-led growth to ensure that incomes continue to converge with European levels; (ii) provide opportunities and broaden participation in growth; and (iii) manage emerging environmental and disaster risks. To increase flexibility and responsiveness, the Bank will deploy of a range of financial instruments beyond traditional lending, and will also explore the use of innovative financial products. The CPS outlines a set of agreed investments and analytical support for FY08 and FY09-decisions on interventions in the second half of the CPS period will be made as part of a mid-term review process anticipated for late CY2009.

6. Recent analytical work by the Bank includes a set of Policy Notes for the new government submitted in July 2007, and reports on decentralization, poverty, labor markets, and public expenditure and financial management. A country economic memorandum and a public investment and expenditure management review are under preparation.

\section{IFC}

7. As of December 2007, the IFC's committed portfolio in Serbia was US\$308 million in 11 projects, the majority of which in the financial sector. In addition, IFC has financed 3 regional funds that include Serbia. Serbia is among IFC's client countries which most benefit from IFC's technical assistance program.

8. In the financial sector, IFC has contributed to the cleaning-up, rehabilitation, and privatization of the banking sector through restructuring of IFC's claims on Serbian banks. IFC supported foreign strategic investors to establish strong financial institutions (Raiffeisen, Banka Intesa, NLB), thus supporting mortgage, consumer, and SME finance. In addition, IFC has supported development of microfinance institutions and introduced new products to the market, such as credit lines to support energy efficiency investments, by investing in ProCredit Serbia.

9. In the corporate sector, IFC supported through its loan and equity investment and advisory services Tigar Rubber company, a leading regional producer of car tires. IFC also assisted Tigar's SME suppliers with a high impact "Supply Chain Management" scheme. IFC has assisted the expansion program of Mercator, the largest Slovenian food retailer, to establish new supermarket stores in Serbia. Mercator's expansion as a retailer is expected to stimulate competition in the sector and improve the variety, price, quality, and delivery of consumer goods.

10. Advisory Services. IFC advisory services are concentrated in four business lines: value addition to firms; business enabling environment; access to finance; and infrastructure advisory operations. Recent activities include: (i) support to mediation centers and courts engaged in the alternative dispute resolution; (ii) support to the Belgrade Stock Exchange in drafting a new Corporate Governance Code and to companies that want to improve their standards and join the A listing of the exchange; (iii) support to a growing number of companies and underprivileged Roma communities engaged in recycling; (iv) support to 
seven companies introducing international standards to increase their competitiveness and exports; (v) working with four municipalities on administrative simplification; and (vi) advising the city government on the concessioning of the Belgrade solid waste and improving water services.

\section{FIAS}

11. FIAS, a multi-donor service of the World Bank Group administrated by IFC, advises member countries on improving their investment climate and on methods to attract FDI. Under a joint World Bank project, FIAS is providing assistance to the government in improving the quality of regulations affecting the cost and risk of doing business in Serbia by developing and implementing tools for reviewing the flow of regulation. FIAS is also implementing several multi-year technical assistance investment generation programs to support Serbia in its efforts to attract FDI.

\section{$M I G A$}

12. As of December 2007, MIGA's outstanding portfolio in Serbia consists of 8 contracts of guarantee with total gross exposure of $\$ 82$ million. MIGA guarantees have primarily supported the expansion of foreign financial institutions in the Serbian banking sector, with some activity also in the manufacturing sector.

Prepared by World Bank staff. Questions may be addressed to Robert Jauncey or Simon Gray. 


\section{Annex III. Serbia: Statistical Issues}

1. The statistical system has been successfully upgraded in recent years with the assistance of the IMF and other bilateral and multilateral institutions. Although international standards are not yet fully met, official data for all sectors are sufficiently good to support key economic analysis and surveillance. In many areas, including monetary and balance of payments sectors, internationally accepted reporting standards have been introduced. However, the country still makes extensive use of definitions that were not updated during the decade when it was isolated from international developments. A page for the Republic of Serbia was introduced in the October 2006 issue of the International Financial Statistics (IFS).

2. In response to the authorities' requests, the Fund provided a series of technical assistance (TA) missions to improve the quality of macroeconomic statistics and support policy analysis. Since 2001, STA conducted four TA missions on monetary and financial statistics, three TA missions on national accounts, one multisector mission, and one balance of payments mission.

\section{A. Real Sector}

3. Real sector data are compiled by the Republic of Serbia Statistical Office (RSSO). Annual current and constant price estimates of GDP by activity and by expenditure are available for 1997-2005. In June 2005, the RSSO started publishing quarterly constant price estimates of GDP using the production approach from 1999 onward. Quarterly GDP estimates are available with a lag of three months after the reference quarter. The RSSO has made commendable efforts to adopt the System of National Accounts (1993 SNA), but there are still problems with the consistency of the GDP estimates from production and expenditure sides. Data sources are still in need of improvement. Official statistics do not incorporate estimates of informal activities, which the RSSO estimated at about 14 percent of GDP in 2003.

4. The RSSO compiles and disseminates monthly indices of retail prices, consumer prices, cost-of-living, producer prices, industrial production, retail sales, and wages, as well as unit-value price indices for imports and exports. The new CPI index, introduced in 2007, appears in line with international standards.

\section{B. Balance of Payments}

5. Balance of payments statistics are compiled by the National Bank of Serbia (NBS). While the data compilation procedures appear appropriate, some components of the balance of payments (e.g., remittances) suffer from substantial deficiencies. The NBS has made commendable efforts to improve its estimation of actual flows. In current account reporting, the NBS could further improve coverage, valuation and classification by adjusting trade and 
services data for transactions not explicitly declared (e.g., repairs, shuttle trade, grants in kind, and tourism). In reporting on financial account transactions, the NBS could improve FDI statistics and remove exchange-rate effects from the estimation of certain financial transactions, including reserves and arrears below the line.

\section{Government Finance}

6. Government finance statistics are compiled by the Ministry of Finance and reported on a monthly basis. Principal data sources are the Republican Treasury and the budget execution reports of the spending ministries and first-level budget units.

7. Since 2001, Serbia has made efforts to bring the existing budget reporting system in line with the Government Finance Statistics Manual 2001 (GFSM 2001) methodology. But full compliance has yet to be achieved as implementation of the new chart of accounts, generally consistent with the classifications of the GFSM 2001, has not been completed. Fiscal data reporting suffers from frequent re-classifications, especially at the level of local governments and social funds. While the data on government payment arrears are available on a quarterly basis, information on accrual of arrears is not available. Aggregate reconciliation of fiscal and monetary data is not conducted on a regular basis. A September 2006 fiscal ROSC mission concluded that there was scope for improving quality, coverage, and comprehensiveness of fiscal data.

\section{Monetary Accounts}

8. Monetary and financial statistics are compiled by the NBS, broadly following the methodology set forth in the Monetary and Financial Statistics Manual, 2000 (MFSM), and meeting the GDDS recommendations with respect to the periodicity and timeliness for the financial sector data. Monetary data is currently reported in Standardized Report Forms.

9. Some improvements could still be made. Depository corporations' claims on clients published in the NBS Statistical Bulletin are on a net-of-provisions basis, while those reported for publication in IFS are on a gross basis, as recommended in MFSM. The coverage of monetary statistics excludes (i) banks in liquidation (as their data are not available on a timely or comparable, $I A S$-specified, basis) and (ii) a group of relatively small deposit-taking institutions that the authorities designate as Other Financial Institutions. The March-April 2006 STA mission proposed that if these two groups of institutions are not covered in the monetary/depository corporations' survey, separate tables on their monetary accounts could be included, for analytical use, in the NBS Statistical Bulletin. Activities of Other Financial Institutions should be monitored and should they become analytically significant, these institutions should be included in the coverage of the monetary/depository corporations' survey. The mission also recommended that the banks' claims on enterprises published in the NBS Statistical Bulletin be disaggregated into claims on public and private enterprises. The NBS began collecting data on nonperforming loans in September 2007. 
Serbia: Table of Common Indicators Required for Surveillance

(As of November 30, 2007)

\begin{tabular}{|c|c|c|c|c|c|}
\hline & $\begin{array}{c}\text { Date of } \\
\text { Latest } \\
\text { Observation }\end{array}$ & $\begin{array}{l}\text { Date } \\
\text { Received }\end{array}$ & $\begin{array}{c}\text { Frequency } \\
\text { of } \\
\text { Data }^{5}\end{array}$ & $\begin{array}{l}\text { Frequency } \\
\text { of } \\
\text { Reporting }^{5}\end{array}$ & $\begin{array}{l}\text { Frequency } \\
\text { of } \\
\text { Publication }^{5}\end{array}$ \\
\hline Exchange rates & $\begin{array}{l}\text { Nov. 30, } \\
2007\end{array}$ & $\begin{array}{l}\text { Nov. } 30 \\
2007\end{array}$ & $\mathrm{D}$ and $\mathrm{M}$ & $\mathrm{D}$ and $\mathrm{M}$ & $\mathrm{D}$ and $\mathrm{M}$ \\
\hline $\begin{array}{l}\text { International reserve assets and reserve } \\
\text { liabilities of the monetary authorities } 1\end{array}$ & $\begin{array}{l}\text { Nov. } 30 \\
2007\end{array}$ & $\begin{array}{l}\text { Nov. 30, } \\
2007\end{array}$ & D & $\mathrm{D}$ & M \\
\hline Reserve/base money & $\begin{array}{c}\text { Nov. 30, } \\
2007\end{array}$ & $\begin{array}{l}\text { Nov. 30 } \\
2007\end{array}$ & $\mathrm{D}$ and $\mathrm{M}$ & $\mathrm{W}$ and $\mathrm{M}$ & $\mathrm{W}$ and $\mathrm{M}$ \\
\hline Broad money & Oct. 2007 & $\begin{array}{l}\text { Nov. 23, } \\
2007\end{array}$ & M & M & M \\
\hline Central bank balance sheet & Oct. 2007 & $\begin{array}{l}\text { Nov. } 23 \text {, } \\
2007\end{array}$ & M & M & M \\
\hline $\begin{array}{l}\text { Consolidated balance sheet of the } \\
\text { banking system }\end{array}$ & Oct. 2007 & $\begin{array}{l}\text { Nov. 23, } \\
2007\end{array}$ & M & M & M \\
\hline Interest rates ${ }^{2}$ & Oct. 2007 & $\begin{array}{l}\text { Nov. 23, } \\
2007\end{array}$ & M & M & M \\
\hline Consumer price index & Nov. 2007 & $\begin{array}{l}\text { Nov. 30, } \\
2007\end{array}$ & M & M & M \\
\hline $\begin{array}{l}\text { Revenue, expenditure, balance and } \\
\text { composition of financing - general } \\
\text { government }^{3}\end{array}$ & $\begin{array}{c}\text { August } \\
2007\end{array}$ & Nov. 2007 & M & M & NA \\
\hline $\begin{array}{l}\text { Revenue, expenditure, balance and } \\
\text { composition of financing- central } \\
\text { government }\end{array}$ & Oct. 2007 & Nov. 2007 & M & M & M/NA 6/ \\
\hline $\begin{array}{l}\text { Stocks of central government and central } \\
\text { government-guaranteed debt }\end{array}$ & $\begin{array}{c}\text { August } \\
2007\end{array}$ & Nov. 2007 & M & M & M \\
\hline External current account balance & Sept. 2007 & $\begin{array}{c}\text { Nov. 13, } \\
2007\end{array}$ & M & M & M \\
\hline Exports and imports of goods and services & Oct. 2007 & $\begin{array}{l}\text { Nov. } 30 \\
2007\end{array}$ & M & M & M \\
\hline GDP/GNP & Q2 2007 & $\begin{array}{l}\text { Sept. 28, } \\
2007\end{array}$ & Q & Q & Q \\
\hline Gross external debt & Sept. 2007 & $\begin{array}{c}\text { Nov. 5, } \\
2007\end{array}$ & M & M & M \\
\hline
\end{tabular}

${ }^{1}$ Includes reserve assets pledged or otherwise encumbered as well as net derivative positions.

${ }^{2}$ Both market-based and officially-determined, including discount rates, money market rates, rates on treasury bills, notes and bonds.

${ }^{3}$ The general government consists of the central government (budgetary funds, extra budgetary funds, and social security funds) and state and local governments. General government reporting is incomplete; local government expenditure data are available only after a six-month lag.

${ }^{4}$ Including currency and maturity composition.

${ }^{5}$ Daily (D), Weekly (W), Monthly (M), Quarterly (Q), Semi-annually (SA), Annually (A), Irregular (I); or Not Available (NA).

${ }^{6}$ Only republican budget data are published. 


\section{Statement by the IMF Staff Representative \\ January 24, 2008}

This statement provides information that has become available since the issuance of the staff report for the 2007 Article IV Consultation. The new information does not alter the thrust of the staff appraisal.

1. Growth slowed in the third quarter of $\mathbf{2 0 0 7}$, due in part to the impact of the summer drought on agriculture, but less than expected. The Statistical Office projects GDP growth of 7.5 percent in 2007, slightly higher than the staff's projection of 7 percent.

2. Inflation increased in December, driven by food and oil prices. End-2007 headline and core inflation reached 10.1 and 5.4 percent respectively, slightly exceeding staff's projections. On December 27, the NBS raised the repo interest rate by 50 bps to 10 percent.

3. The current account deficit widened to $\mathbf{1 6 . 6}$ percent of GDP between January and November 2007, fueled by high import growth. The current account deficit for the full year 2007 is likely to exceed staff's projection of 16.1 percent of GDP.

4. Credit also rose sharply. Its twelve-month growth, adjusted for inflation, increased from 28 percent in October to 36 percent in November.

5. Fiscal deficits could be larger than expected. Preliminary staff estimates for 2007 indicate that the deficit could exceed projections in the staff report by $1 / 2$ to 1 percentage point of GDP, due to high end-year spending on goods and services, capital investment, and pension arrears. The 2008 budget, adopted on December 26, 2007, envisages a deficit that exceeds the staff projection by about $1 / 4$ percentage point of GDP, largely on account of higher spending by social funds.

6. Financial markets have remained volatile since the end of 2007 amid global financial turmoil and political uncertainties (see text figure).

\section{Based on a government decision,} Serbia is expected to sign an agreement with Russia on cooperation in the oil and gas industries on January 25. Staff understands that the agreement will enable talks to begin on a contract with Russia's Gazprom on an underground gas storage facility and a gas pipeline, as well as on the sale and development of the state-owned oil company NIS.

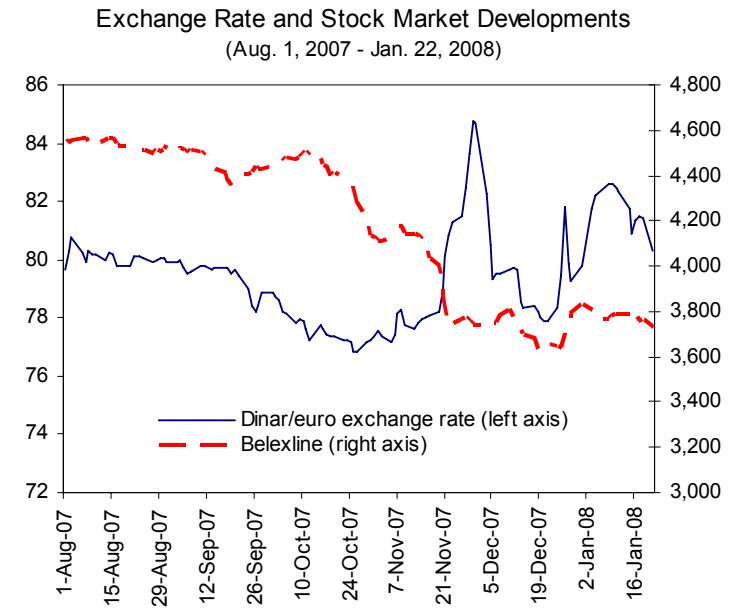


Public Information Notice (PIN) No. 08/11

FOR IMMEDIATE RELEASE

February 5, 2008
International Monetary Fund

$70019^{\text {th }}$ Street, NW

Washington, D. C. 20431 USA

\section{IMF Executive Board Concludes 2007 Article IV Consultation with the Republic of Serbia}

On January 28, 2008, the Executive Board of the International Monetary Fund (IMF) concluded the Article IV consultation with the Republic of Serbia. ${ }^{1}$

\section{Background}

Serbia continues to grow strongly-a welcome result of the structural reforms of the past. Real GDP growth is projected to reach about 7 percent in 2007. Much has been done since 2000: inflation has come down significantly; the banking sector was restructured; and hundreds of companies were privatized. As a result, for the first time in years, the corporate sector posted aggregate profits.

However, sustaining the reform momentum has been a challenge and weaknesses in the corporate sector persist. Structural reforms stalled in 2006-07 and substantial progress-and growth-has been achieved only in a handful of sectors. State- and socially owned enterprises continue to drain domestic savings while fixed investment remains low. With slow job creation, employment continued declining and unemployment remained high at 21 percent in 2006.

Nevertheless, capital inflows surged, particularly in 2006 , boosted by privatization-related receipts but also by foreign borrowing -mostly medium- and long-term. This led to rising, particularly private, external debt.

\footnotetext{
${ }^{1}$ Under Article IV of the IMF's Articles of Agreement, the IMF holds bilateral discussions with members, usually every year. A staff team visits the country, collects economic and financial information, and discusses with officials the country's economic developments and policies. On return to headquarters, the staff prepares a report, which forms the basis for discussion by the Executive Board. At the conclusion of the discussion, the Managing Director, as Chairman of the Board, summarizes the views of Executive Directors, and this summary is transmitted to the country's authorities.
} 
The large inflows allowed for significant official reserve accumulation $(71 / 2$ months of imports as of November 2007), but also led to a surge in demand. This was compounded by rapid credit growth and expansionary domestic policies-large wage increases in the public sector, income tax cuts, and fiscal deficits in 2006-07. Given domestic supply rigidities-and a drop in remittances - the current account deficit continued to widen, reaching $161 / 2$ percent of GDP in the period January-November 2007.

Expansionary fiscal policies contributed to the widening of external imbalances. Driven by rising expenditure, the fiscal balance has deteriorated by over $2 \frac{1}{2}$ percent of GDP since 2005 . In 2006 , the deficit reached $1 \frac{1}{2}$ percent of GDP-some 4 percentage points adrift of the target envisaged in February 2006 under the Extended Arrangement with the Fund. In 2007, a deficit of $13 / 4$ percent of GDP is expected.

Despite prudential tightening, credit growth remained largely unabated, as competition in the banking sector intensified. Coupled with high euroization of credit, this increased financial sector vulnerabilities, although banking sector soundness has so far been preserved as rigorous risk classification rules and high provisioning, reserve, and capital requirements have kept banks well capitalized.

The new monetary policy framework introduced in mid-2006 has so far been successful in achieving low inflation, as core inflation declined from $14 \frac{1}{2}$ percent at end-2005 to $5 \frac{1}{2}$ percent at end-2007-within the 4-8 percent target range for the year-despite headline inflation reaching 10 percent. The decline in inflation was aided by double-digit nominal and real appreciation. Monetary policy remained conservative in 2007 as the nominal appreciation persisted through most of the year.

A combination of weak structural, expansionary fiscal, and tight monetary policies in the past two years have resulted in a loss of competitiveness. Large pay raises granted ahead of the elections raised labor costs, and even in industry, wage growth outstripped productivity gains in 2006, although this was partly reversed in the first half of 2007. Nevertheless, export shares remained on an upward trend despite the sharp real effective exchange rate appreciation over the past year and a half.

\section{Executive Board Assessment}

Executive Directors welcomed the robust growth with moderate inflation in 2007, and recognized that this performance reflected, in large part, the impact of tight monetary policies and the authorities' progress on structural reforms and privatization during the past 7 years of transition. However, as a result of the rapid growth of domestic demand fueled by large wage increases, credit growth, and expansionary fiscal policies, imbalances have increased, the current account deficit has widened, private external debt has rapidly accumulated, and vulnerabilities have risen. Directors, therefore, recommended a significant rebalancing of policies, with enhanced structural reforms and tighter fiscal policy. 
Directors noted that financial stability risks have been managed by building adequate buffers and rigorous prudential regulations. Large capital inflows, while allowing significant official reserve accumulation, have complicated macroeconomic management by boosting domestic demand. Directors considered that international financial market turbulence, increased volatility in domestic markets, and continuing political uncertainties have added to underlying vulnerabilities, and underscored the importance of stability-oriented macroeconomic policies.

Several Directors agreed that the present policy mix of loose fiscal, tight monetary, and until recently slow-moving structural policies are reflected in an overvalued real exchange rate, although the size of the overvaluation is uncertain. Others, however, pointed to more benign indicators of competitiveness. Directors cautioned that under such policies, external imbalances are likely to persist, with a continuing large current account deficit and rising external debt.

Directors observed that fiscal policy is the main short-term macroeconomic tool available for reducing Serbia's external imbalances. They noted that targeting a tighter fiscal stance than that set out in the budget document for 2008 will help contain excess demand pressures and increase the likelihood of a turnaround in the current account. Fiscal restraint will continue to be needed until the effects of structural reforms take hold to support monetary policy and create space to finance growth-enhancing infrastructure needs. Fiscal consolidation should focus on expenditure savings, in particular by curbing discretionary spending and subsidies, controlling public sector wages and pension benefits, and prioritizing capital spending.

Directors welcomed the tight monetary policy, which has been successful in containing inflationary pressures despite food and oil price shocks. They encouraged the authorities to aim at keeping inflation at the middle of the 3-6 percent core inflation target in 2008, and to entrench low inflation, including through the adoption of formal inflation targeting, once necessary conditions are in place. Competitiveness concerns should be addressed through corporate restructuring and wage moderation rather than exchange rate intervention, which should continue to focus on smoothing shocks.

Directors viewed corporate sector reforms and further measures to improve the business climate as key to enhancing growth and employment, while noting that these will take time to bear fruit. They welcomed the renewed efforts to accelerate privatization and to implement bankruptcy procedures of socially owned enterprises and urged completion of the process as soon as possible. Directors supported opening stakeholding in state-owned utilities to private sector participation.

Directors supported further strengthening of the regulatory and supervisory framework to manage increasing financial sector risks. The prudential framework should remain restrictive, particularly while macroeconomic and financial vulnerabilities persist. This requires continued monitoring of banks' non-performing loans, resilience to shocks, and cross-border supervisory coordination. Developing domestic capital markets should also contribute to growth and financial stability in the medium term. 
Public Information Notices (PINs) form part of the IMF's efforts to promote transparency of the IMF's views and analysis of economic developments and policies. With the consent of the country (or countries) concerned, PINs are issued after Executive Board discussions of Article IV consultations with member countries, of its surveillance of developments at the regional level, of post-program monitoring, and of ex post assessments of member countries with longer-term program engagements. PINs are also issued after Executive Board discussions of general policy matters, unless otherwise decided by the Executive Board in a particular case. The staff report (use the free Adobe Acrobat Reader to view this pdf file) for the 2007 Article IV Consultation with the Republic of Serbia is also 
Serbia: Selected Economic and Financial Indicators, 2004-08 ${ }^{1 /}$

\begin{tabular}{rrrrrr}
\hline 2004 & 2005 & 2006 & 2007 & 2008 \\
Est. & Proj. \\
\hline
\end{tabular}

(Change in percent)

\section{Real economy}

Real GDP

Retail prices (end of period)

Core retail prices (end of period)

\section{General government finances}

Revenue (excl. grants)

Expenditure

Overall balance (cash basis, excl. grants)

Gross debt

of which: Forex-denominated (in percent of

\section{Monetary sector (end of period)}

Credit to non-government

\section{Interest rate}

NBS bills / Repo rate

\section{Balance of payments}

Current account balance, before grants

Current account balance, adjusted 2/

Exports of goods (f.o.b.)

Imports of goods (f.o.b.)

Current account balance, after grants

External debt (end of period; billions of \$)

Gross official reserves (in billions of \$)

(In months of prospective imports of GNFS)

Exchange rate (dinar/euro, period average)

Real Effective Exchange Rate (annual average

\begin{tabular}{rrrrr}
8.4 & 6.2 & 5.7 & 7.0 & 6.0 \\
13.7 & 17.7 & 6.6 & 10.1 & 7.2 \\
11.0 & 14.5 & 5.9 & 5.4 & 4.5 \\
\multicolumn{4}{c}{ (In percent of GDP) }
\end{tabular}

$\begin{array}{lllll}41.4 & 41.3 & 40.7 & 41.3 & 41.2\end{array}$

$\begin{array}{lllll}41.4 & 40.6 & 42.3 & 43.1 & 43.3\end{array}$

$\begin{array}{lllll}0.0 & 0.7 & -1.5 & -1.8 & -2.1\end{array}$

$\begin{array}{lllll}63.1 & 54.1 & 39.6 & 37.6 & 34.5\end{array}$

$\begin{array}{lllll}85.7 & 90.8 & 89.5 & 87.6 & 85.8\end{array}$

(12-month change, in percent) $\begin{array}{llll}16.3 & 19.2 & 14.0 & 10.0\end{array}$

(In percent of GDP, unless otherwise

Sources: Serbian authorities; and IMF staff estimates and projections.

1/ Excluding Kosovo (with the exception of external debt).

2/ Corrected for the surge in imports and remittances ahead of the VAT introduction in 2005. 


\section{Statement by Thomas Moser, Executive Director for the Republic of Serbia and Srboljub Antic, Senior Advisor to Executive Director January 28, 2008}

1. We thank staff for the comprehensive set of documents, which present a wellbalanced picture of the economic situation in Serbia. The report spells out very clearly the significant challenges that the authorities continue to face during a very delicate period in Serbia's transition to a full-fledged market economy. On behalf of the authorities, we would like to thank staff for the constructive policy discussions and the valuable recommendations. As in the past, the Serbian authorities consent to the publication of the staff papers.

2. The staff report calls attention to the increasing vulnerabilities and risks surrounding the Serbian economy. Prolonged political elections and a demanding period ahead, during which some long-standing and delicate political issues will be tackled, add to the rising economic vulnerabilities. Our authorities are fully aware of the risks and will do their best to balance them, while preparing for stronger policy actions for the rest of 2008 .

3. As the staff report points out, the Serbian economy is growing strongly with moderate inflation. But large capital inflows are complicating macroeconomic management and external and financial sector vulnerabilities are increasing. These vulnerabilities are rising also in other regional countries. The authorities have implemented the recommendations of the 2005 FSAP and continue to strengthen the regulatory and supervisory framework to address the remaining financial stability concerns.

4. The high and rising current account deficit is probably the main economic challenge for Serbia. The authorities share the staff's concern, but at this juncture there are some differences with regard to the timing, the scale, and the composition of the needed policy response. Particularly, the authorities would like to consider a combination of all available policies and instruments to address the problem. These differences should be the subject of continued dialogue with staff.

5. The fiscal policy stance takes center stage in the staff's recommendations. The loosening of the fiscal policy stance has started in the second part of 2006, when the government received large privatization revenues and decided to use them to meet urgent infrastructure needs. Elections in 2007 and an extended period of government formation created pressure for wage increases, which where implemented in mid-2007. Moreover, the budget for 2008 was strongly influenced by political promises made before the parliamentary elections, and the prolonged election cycle makes it difficult to address the needed adjustment. A further component was the last increase in pensions based on the wage component in the beginning of 2008 as a result of the change in the indexation mechanism to cost of living only. We would like to stress that a rebalancing of the 2008 budget is still possible.

6. Strong fiscal and privatization revenues have created fiscal space to improve the country's infrastructure. Due to disinvestment in the 1990s and a very low level of public 
investment after 2000, Serbia's infrastructure is in poor shape. The increase in public investment therefore is seen as an important contribution to the country's development and the improvement of the business climate. The size of the planned capital expenditure through the National Investment Plan (NIP) in 2008 is around 4.5 percent of GDP.

7. Although headline inflation was higher than projected due to energy and food prices, monetary policy has kept core inflation well within the targeted range (4-8 percent). Monetary policy will continue to be tight in 2008. The National Bank of Serbia (NBS) has set the targeted range for the core inflation objective for 2008 at 3-6 percent. The level of the inflation objective is thus lower and the targeted range narrower with the aim of achieving price stability by a process of continued gradual disinflation. In choosing the new range, the NBS has taken into account that the level should be high enough to allow for smooth adjustment of the relative prices during the restructuring of the Serbian economy and to put minimal pressure on the nominal exchange rate.

8. The Serbian dinar has experienced increased volatility in Q4 2007. Pursuing a softmanaged floating exchange regime, the NBS intervened once in the foreign exchange market to prevent excessive daily fluctuations. The size of intervention was small, but big enough to stabilize the market. Regardless of this episode, the NBS will continue to move out of the foreign exchange market, as shown in 2007 by the small number of days in which the NBS was active on the foreign exchange market (only 17). The NBS clearly intends to make the exchange rate more flexible and more dependent on market forces.

9. Structural reforms have been reinvigorated after the new government took office in May 2007. The number of auctions in the second half of 2007 has been doubled in comparison with the first half of 2007. The number of tenders for big companies has also substantially increased. However, the most important action was that bankruptcy procedures were finally fully implemented in long standing cases. The prices achieved at some of the bankruptcy auctions, mainly with companies at attractive locations and land for construction, were unexpectedly high. The government plans to finalize the privatization process in 2008 with the exception of utilities.

10. The utility sector will undergo some long overdue changes. The privatization of the oil company (NIS) and the air carrier (JAT) will start in the first half of 2008. Shares of 5 utilities (energy and telecommunications) and the state pharmaceutical company will be distributed to the public (15 percent) and current and past employees of the utilities (2.5 percent). The process of share distribution will last 6 months, while some time restrictions for the sale of shares will be applied.

11. In conclusion, the authorities are aware that growing economic vulnerabilities should be addressed in the near future. They would like to intensify the dialogue with staff in order to formulate adequate answers to the vulnerabilities and risks, possibly in the form of closer future relations with the IMF. 